\author{
UNIVERSIDADE DE SÃO PAULO \\ FACULDADE DE FILOSOFIA, LETRAS E CIÊNCIAS HUMANAS \\ DEPARTAMENTO DE GEOGRAFIA \\ PROGRAMA DE PÓS-GRADUAÇÃO EM GEOGRAFIA HUMANA
}

LIDIANA CRUZ DA COSTA

Versão Corrigida

\title{
AS DIFERENTES REPRESENTAÇÕES DO TERRITÓRIO GUARANI DA SERRA DO MAR -SP.
}

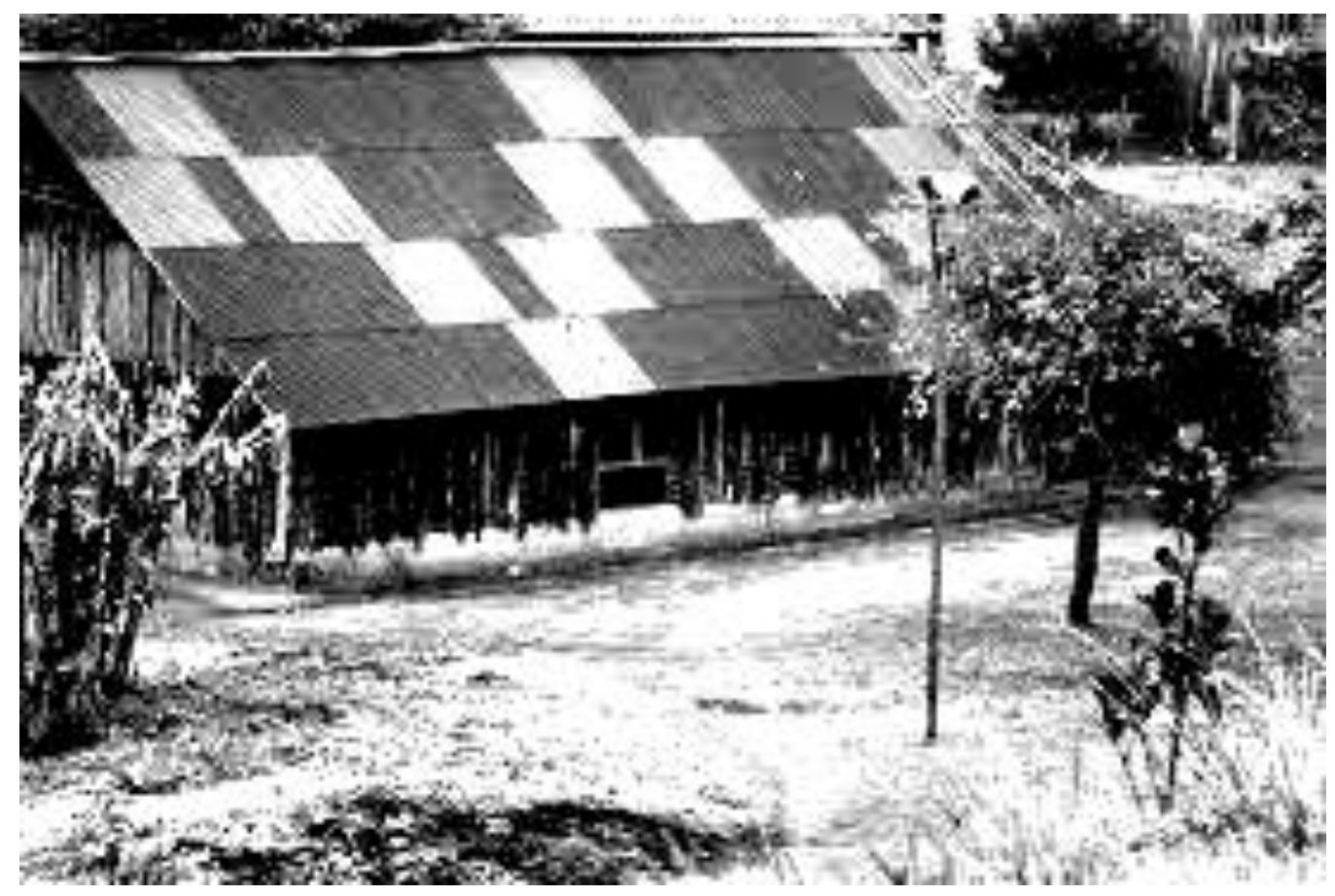

Lidiana Cruz da Costa 


\section{AS DIFERENTES REPRESENTAÇÕES DO TERRITÓRIO GUARANI DA SERRA DO MAR -SP.}

Versão corrigida

Dissertação de mestrado apresentada junto ao Programa de Pós-Graduação de Geografia Humana da Universidade de São Paulo - USP, FFLCH Faculdade de Filosofia, Letras e Ciências Humanas.

Orientação: Prof ${ }^{a}$ Fernanda Padovesi Fonseca.

De acordo:

Prof ${ }^{a}$ Fernanda Padovesi Fonseca

São Paulo

2018 
Autorizo a reprodução e divulgação total ou parcial deste trabalho, por qualquer meio convencional ou eletrônico, para fins de estudo e pesquisa, desde que citada a fonte. da Serra do Mar- SP / Lidiana Cruz da Costa orientador Fernanda Padoveai Poneeca. - Säo Paulo, 2017.

$154 \mathrm{f}$.

Dimertaç̃o (Meatrado) - Faculdade de Filonofia, Letran e Ciêncian Humanas da Universidade de Säo Paulo. Departamento de Geografia. Área de concentração: Geografia Humana.

1. Guarani. 2. Repreaentaçōen. 3. Territ6rio. 4. Cartografia. 5. Delimitaç̄̃o. I. Fonueca, Fernanda Padoveni, orient. II. Titulo. 


\section{AGRADECIMENTOS}

Agradeço aos Guarani pela convivência, disposição e abertura para a realização da pesquisa.

Agradeço a minha família pelo amor e incentivo.

Agradeço a Luciene Cristina Risso por incentivar e acreditar na realização dessa pesquisa.

Agradeço a Fernanda Padovesi Fonseca pela orientação.

Agradeço aos professores Manoel Fernandes, Sueli Furlan e Marcelo Martinelli por compartilhar momentos incríveis na realização das disciplinas de pós graduação.

Agradeço ao meu querido Vinícius Almeida pelos ensinamentos no desenvolvimento dos mapas.

Agradeço a todos que direta ou indiretamente contribuíram para a construção das ideias aqui apresentadas. 


\section{SUMÁRIO}

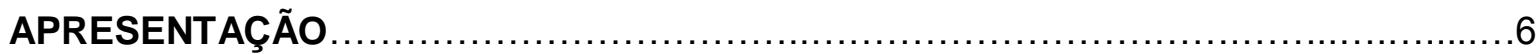

INTRODUÇÃO

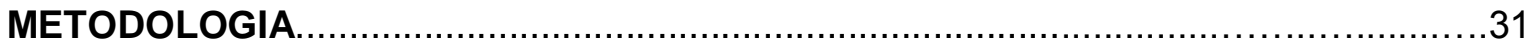

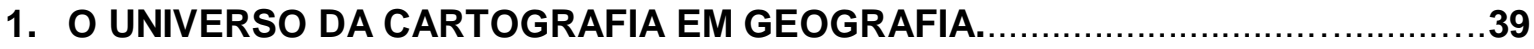

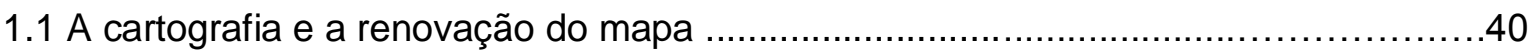

1.2 A cartografia como possibilidade de luta e resistência ................................45

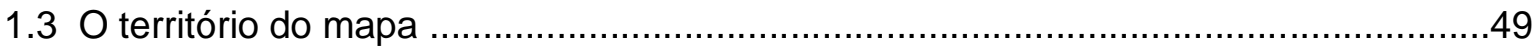

1.4 A constituição da Terra indígena Tenondé Porã ..............................................54

2. MOBILIDADE ESPACIAL E REALIDADE ATUAL DOS GUARANI MBYÁ $\ldots \ldots \ldots \ldots 62$

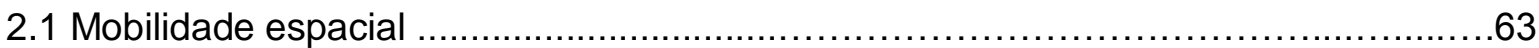

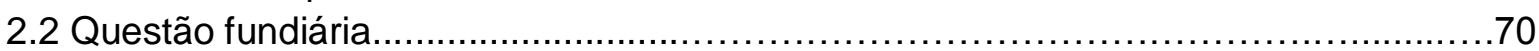

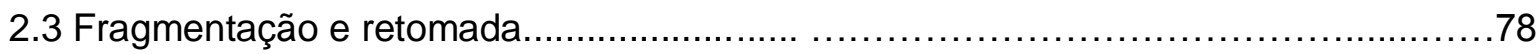

2.4. A caça, pesca e agricultura na Tekoá Tenondé Porã...............................................84

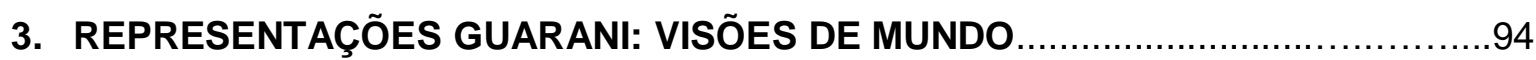

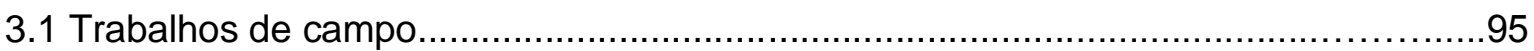

3.2 As Representações como expressão cultural do coletivo...................................107

3.3 Território Guarani em redes: Articulações Possíveis........................................110

$3.4 \mathrm{O}$ território no ponto de vista zenital....................................................

3.5 A representações dos problemas ambientais......................................................133

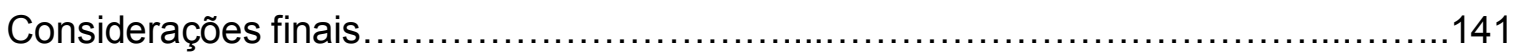

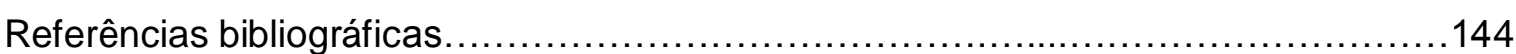

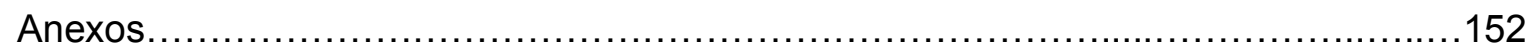


COSTA, Lidiana Cruz da. As diferentes representações do Território Guarani da Serra do Mar. 2017. 155 f. Dissertação (Mestrado) - Faculdade de Filosofia, Letras e Ciências Humanas da Universidade de São Paulo, São Paulo, 2017.

\section{RESUMO}

Esta pesquisa tem como objetivo investigar as diferentes formas de representação do território Guarani localizado na Serra do Mar - no estado de São Paulo. Visa a compreensão de como é possível apreender o território do outro - do Guarani- como esse outro é capaz de representá-lo, constituindo-se as representações desse território o objeto de estudo. As representações são as geradoras das questões que serão discutidas e problematizadas. Para isso, este trabalho contou com a produção e análise de diferentes representações do território Guarani, constituído por mapas com a delimitação a partir da concepção Guarani do que eles denominam de território, com entrevistas formais e informais, pesquisa bibliográfica e observação em campo. $O$ conceito de território foi central nessa pesquisa devido ao contexto territorial que as aldeias da Terra Indígena Tenondé Porá estão inseridas. Atualmente, somente o núcleo habitacional de 26 hectares da aldeia Tenondé Porá e Krukutu estão demarcados, o que tem como consequência a impossibilidade do desenvolvimento do modo de ser tradicional Guarani, baseado no Nhadereko. Desse modo, há cerca de 20 anos a FUNAI desenvolve estudos voltados para o processo de ampliação dos limites da Terra indígena Tenondé Porá. Essa ampliação possibilitaria a união dos limites administrativos das Terras indígenas da Serra do Mar, as Terras Indígenas do Aguapeú, Rio Branco, Itaóca e Tenondé Porá, constituindo essa união o que os Guarani da Aldeia Tenondé Porá denominam de fragmento do território Guarani da Serra do Mar, por ser um território contínuo e contíguo, incorporando a área destinada à caça, pesca e coleta de materiais. Esta pesquisa possibilitou constatar que os territórios Guarani são ligados por meio das redes de parentesco, bem como por meio das redes de trocas de mercadoria, cultura e conhecimento, o que não anula, mas reforça a necessidade de garantia das áreas destinadas à caça, à pesca e à coleta de materiais por meio da circulação e mobilidade. Por serem fundamentais para entender - que se denomina território Guarani, alguns conceitos geográficos como Terra, distância, fronteira, mobilidade e rede foram problematizados. O resultado da pesquisa demonstra que há a necessidade de entender as representações a partir dos seus contextos, de pesquisa bibliográfica e, principalmente, do diálogo com o produtor, bem como sua relação com outras representações. 
COSTA, Lidiana Cruz da. As diferentes representações do Território Guarani da Serra do Mar. 2017. 159 f. Dissertação (Mestrado) - Faculdade de Filosofia, Letras e Ciências Humanas da Universidade de São Paulo, São Paulo, 2017.

\begin{abstract}
This research aims to investigate the different forms of representation of the Guarani territory located in the Serra do Mar - states of São Paulo and doing so to understand how it is possible to apprehend the territory of the other - Guarani's - and to understand how this other is able to represent it. Our object of study is the representations of this territory. Representations are the generators of the issues that will be discussed and questioned. For this purpose, the work involved the production and analysis of different representations of this territory, constituted by maps with the delimitation from the Guarani conception of what they call "territory", formal and informal interviews, bibliographical field research and observation. The concept of territory is central due to the territorial context that the villages of Tenondé Porá Indigenous Land are inserted. Currently only the 26-hectare housing complex of the Tenondé Porá and Krukutu villages are demarcated, resulting in the impossibility of developing the traditional Guarani mode based on Nhadereko. Thus, about 20 years ago, FUNAI developed studies aimed at expanding the boundaries of Tenondé Porá indigenous land. This extension would allow the union of the administrative boundaries of the indigenous lands of the Serra do Mar, the Indigenous Lands of Aguapeú, Rio Branco, Itaóca and Tenondé Porá. This union is what the Guarani of the Tenondé Porá Village denominate as a fragment of the Guarani territory of the Serra do Mar, because it is a continuous and contiguous territory, incorporating the area destined to hunting, fishing and collecting materials. This research made it possible to verify that the Guarani territories are linked through kinship networks, as well as through networks of merchandise, culture and knowledge exchange, which does not nullify, but reinforces the need to guarantee areas for hunting, fishing and collection of materials through circulation and mobility. Some geographical concepts were problematized because they are fundamental to understand what is called Guarani territory, they are: land, distance, frontier, mobility and networks. The result of the research shows that there is a need to understand the representations from their contexts, bibliographical research and mainly the dialogue with the producer, as well as their relation with other representations.
\end{abstract}




\section{LISTA DE FIGURAS}

Figura 01: Vista aérea da Aldeia -aldeia Barragem/Tenondé Porã $\quad 7$

Figura 02: Casa de reza da Aldeia Tenondé Porã 8

Figura 03: Núcleo Habitacional 9

Figura 04: Mapa de localização Pontual das aldeias Guarani de São 11

Paulo

Figura 05: Mapa de localização de Terras indígenas em São Paulo 19

Figura 06: Mapa do fragmento do território Guarani da Serra do Mar 20

Figura 07: Mapa da Terra indígena Tenondé Porã 21

Figura 08: Mapa da área homologada da Terra indígena Tenondé Porã 22

Figura 09: Mapa das aldeias da Terra Indígena Tenondé Porã 23

Figura 10: Mapa de sobreposição 24

Figura 11: Dados demográficos 26

Figura 12: Demarcações de Terras indígena no Brasil 56

Figura 13: Demarcações de Terras indígena no Brasil 57

Figura 14: Demarcações de Terras indígena no Brasil 57

Figura 15: Mapa da presença Guarani na América do Sul 64

Figura 16: Mapa Terra indígena e sobreposições 72

Figura 17: Foto da Roça Guarani 1980

Figura 18: Foto da Roça Guarani 1988

Figura 19: Foto do Plantio de Milho Tradicional na aldeia Tenondé Porã 88

Figura 20: Alimentos tradicionais Guarani 89

Figura 21: Preparo de alimentos pelas crianças da comunidade 92

Figura 22: Crianças aprendem a plantar milho em Guarani 93

$\begin{array}{ll}\text { Figura 23: Mapa inicial elaborado com a comunidade } & 100\end{array}$

$\begin{array}{ll}\text { Figura 24: Placa de entrada da comunidade } & 104\end{array}$

Figura 25: Casa construída no projeto habitacional 104

Figura 26: Reunião da assembléia yvy rupa 106

Figura 27: Representação do território por Kupato Kaiapó 115

Figura 28: Representação desenvolvida para o território Guarani 115

Figura 29: Mapa do núcleo habitacional por Adriano 117 
Figura 30: Mapa do núcleo habitacional por Edmilson 118

Figura 31: Mapa de aldeia 122

$\begin{array}{ll}\text { Figura 32: Mapa de aldeia } & 123\end{array}$

Figura 33: Representação do território 124

Figura 34: Casa de reza da aldeia Tenondé Porá 127

$\begin{array}{lr}\text { Figura 35: Ceci Tenondé Porá } & 129\end{array}$

Figura 36: Ceci Tenondé Porá 129

Figura 37: Escola estadual Guyrá pepó 130

Figura 38: Mapa do Núcleo Habitacional 133

Figura 39: Vista da Comunidade Tenondé Porá 134

Figura 40: Representação do artesanato e cosmologia 136

$\begin{array}{ll}\text { Figura 41: Artesanato Guarani } & 137\end{array}$ 


\section{LISTA DE ABREVIAÇÕES}

FUNAI: Fundação Nacional do Índio

TI: Terra Indígena

MMA: Ministério do Meio Ambiente

GESP: Governo do Estado de São Paulo

CTI: Centro de Trabalho Indigenista

RMSP: Região Metropolitana de São Paulo

PGC: Programa Grande Carajás

USP: Universidade de São Paulo

UNESP: Universidade Estadual Paulista

CIMI: Conselho Indigenista Missionário

PNGTA: Política Nacional de Gestão Territorial e Ambienta

FUNAI: Fundação Nacional do Índio 


\section{APRESENTAÇÃO}

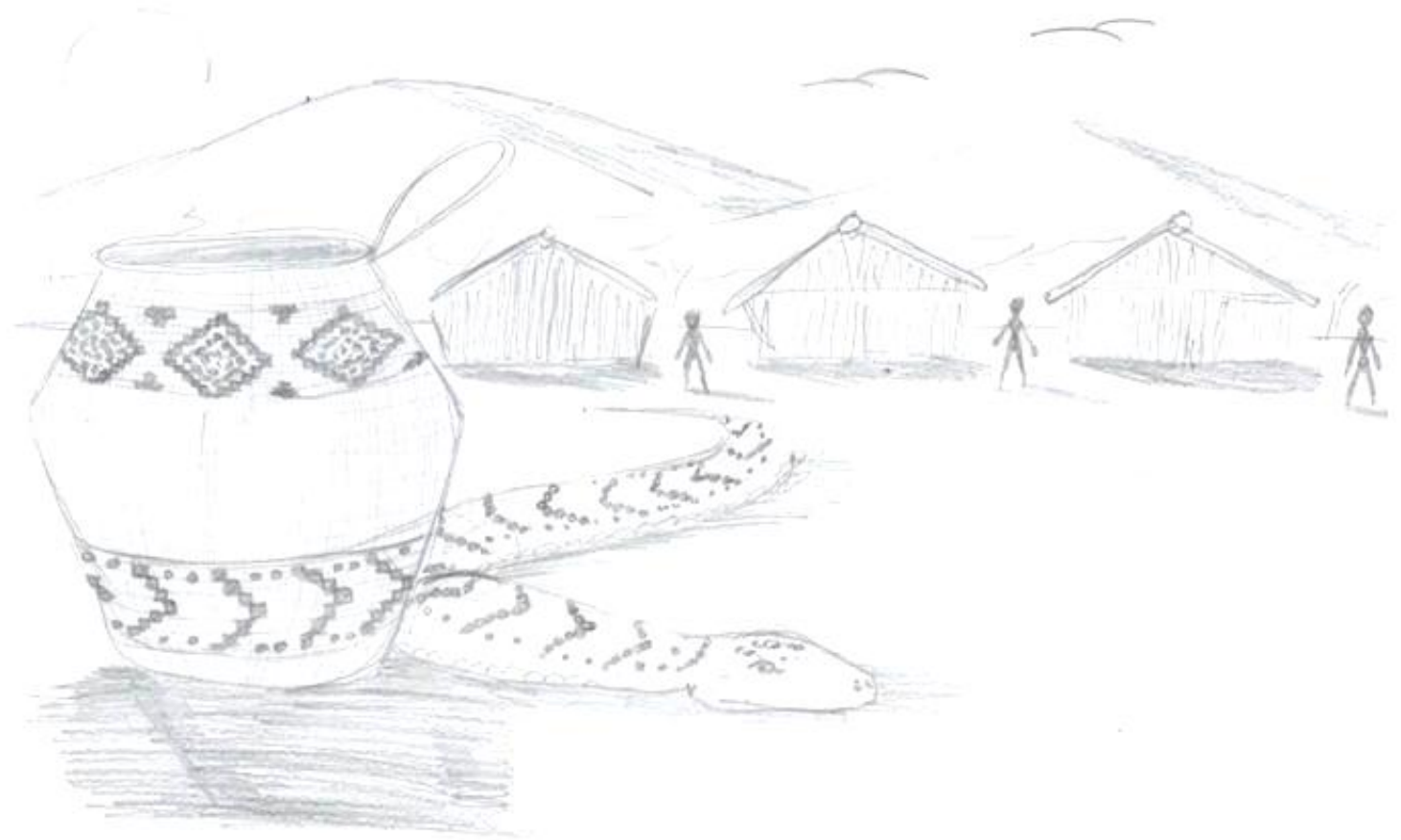

FONTE: Márcio Mirim, 24 anos, realizado em 17/09/2015. 
FIGURA 1: VISTA AÉREA DA ALDEIA BARRAGEM/ TENONDÉ PORÃ

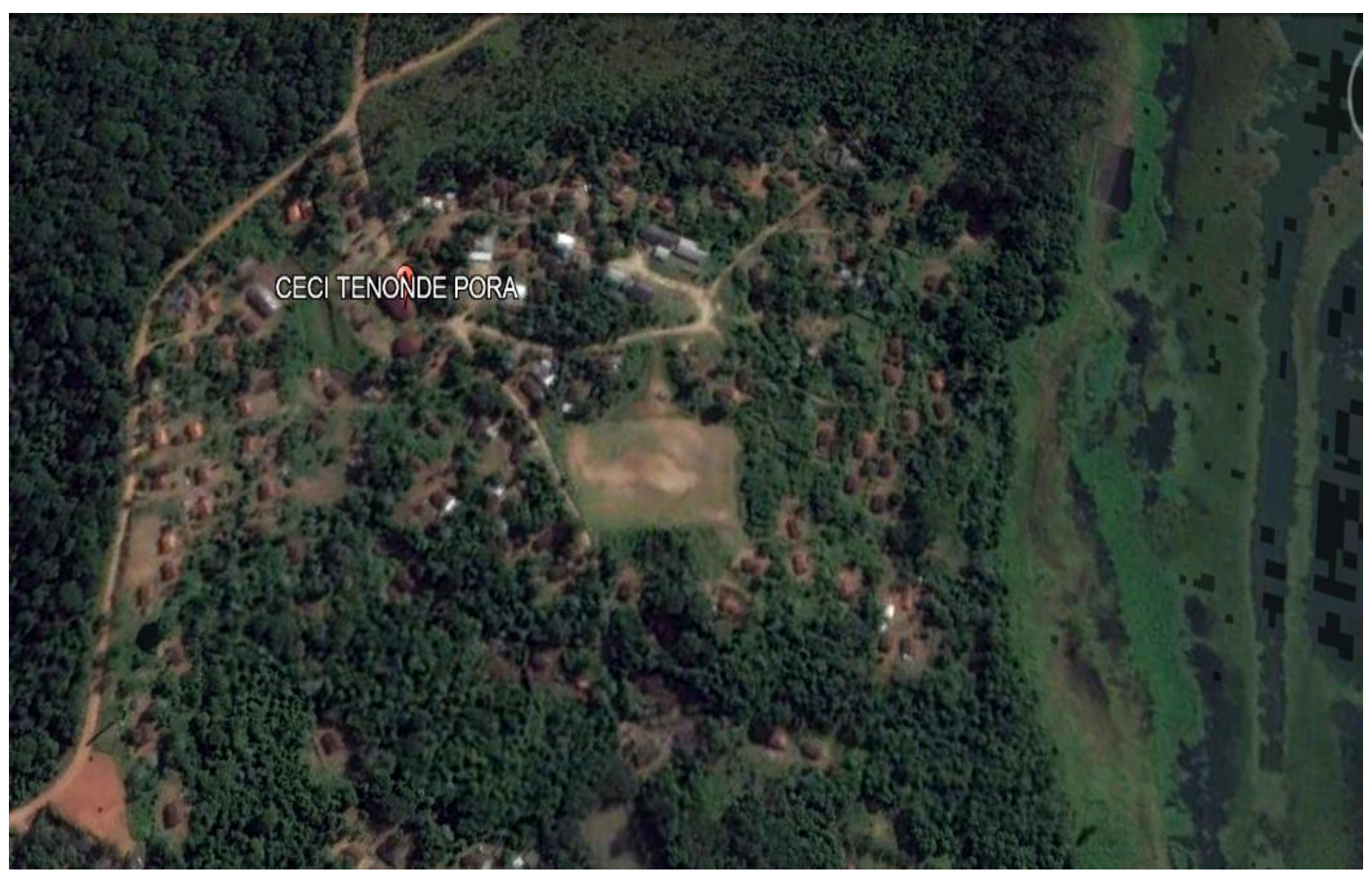

FONTE: Google Earth (2017).

\footnotetext{
${ }^{1}$ A aldeia Guarani Mbyá era chamada de Barragem, posteriormente passou a ser chamada de Tenondé Porá.
} 
Figura 2 - Foto Casa de Reza da Aldeia Tenondé Porã

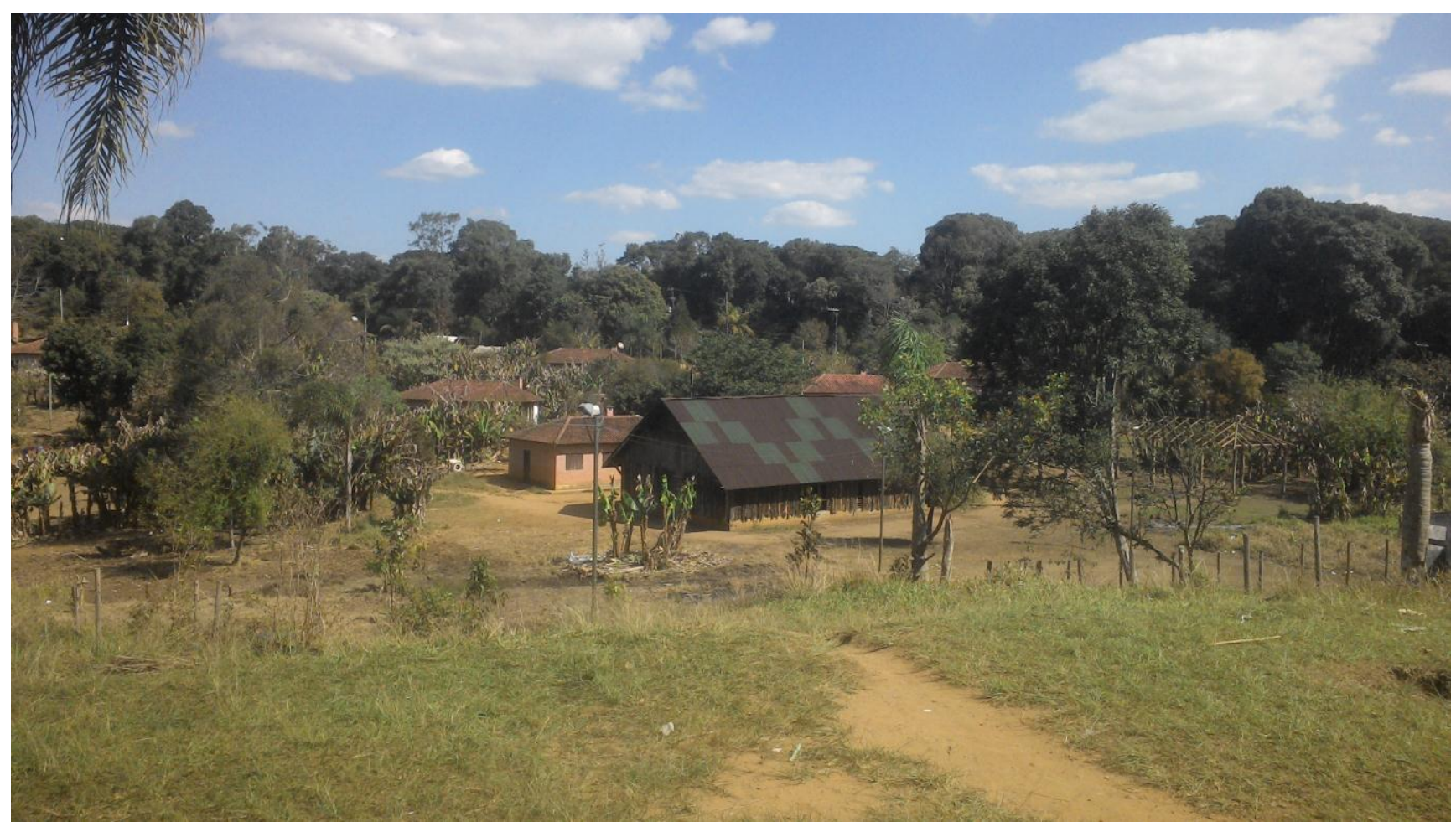

Fonte: Costa (2016). 
Figura 3 - Foto do Núcleo Habitacional da Aldeia Tenondé Porã

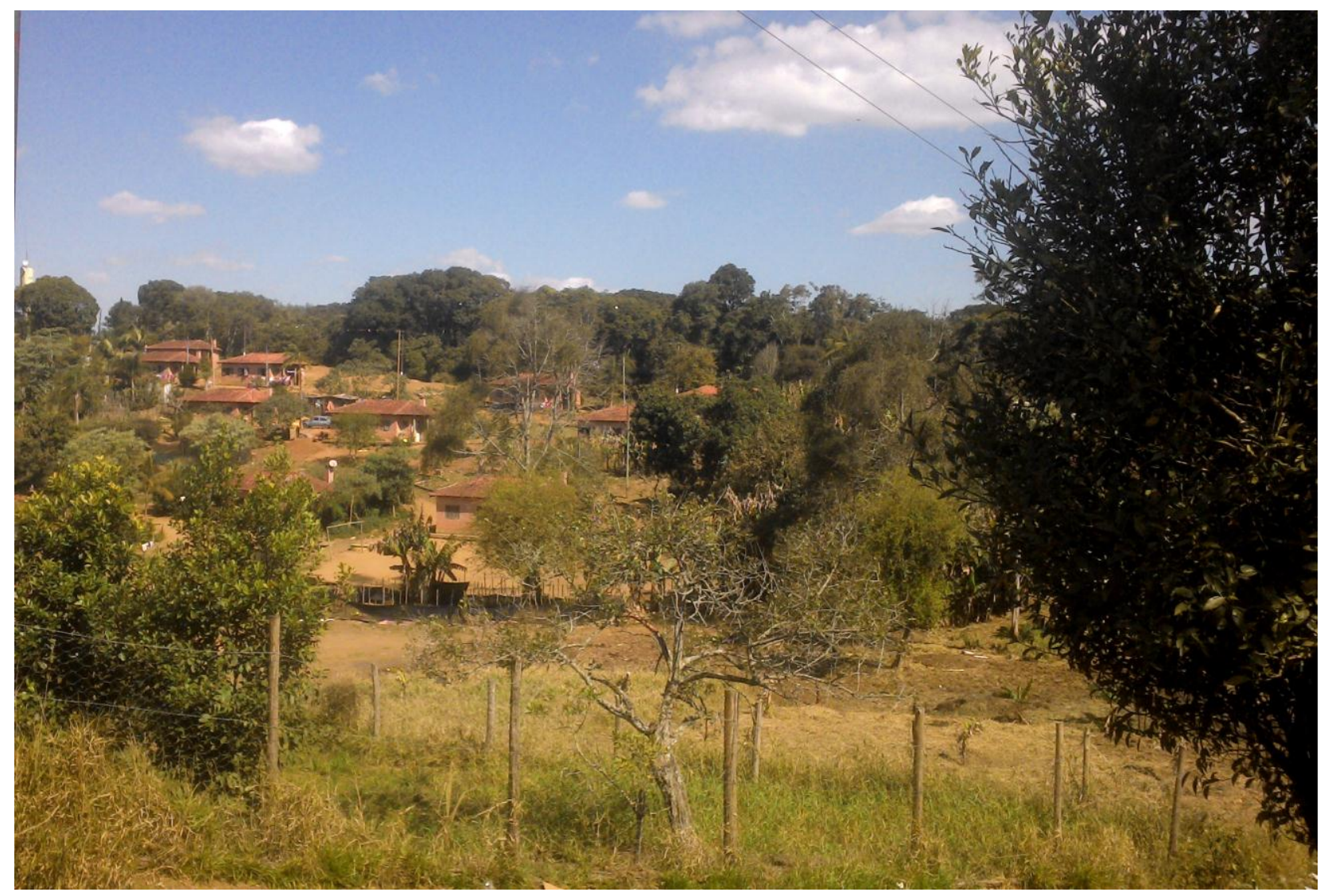

Fonte: Costa (2016).

Esta apresentação começa refletindo sobre as palavras de um sábio indígena que explicou um ponto central da diferença entre a concepção indígena e a ocidental sobre o sentido que damos a algo que denominamos como conhecimento. Segundo ele, há uma diferença espaço-temporal entre as sociedades indígenas e a sociedade ocidental. Davi Kopenawa (2015) chamou a sociedade ocidental de "povos da mercadoria". O conhecimento para essa sociedade é, antes de tudo uma "mercadoria", e o desenvolvimento de uma pesquisa "científica" se condiciona a esse tempo. O conhecimento como "mercadoria" é uma visão reducionista que "marginaliza" diferentes formas de 
conhecimento, como a dos grupos indígenas. Segundo um Davi Guarani Mbyá $(2015)^{2}$ : "O conhecimento na sociedade dos juruás ${ }^{3}$ vem de forma acelerada e destruidora. A diferença é que essa sociedade prepara o ser humano para o mercado e não para a vida". É importante entender essas diferenças para poder adequar as pesquisas dentro de um universo que é limitado de possibilidades.

Este trabalho também é fruto de um interesse e de uma experiência pessoal em entender a constituição e a fragmentação dos territórios indígenas, particularmente da comunidade Guarani Mbyá Tekoá Tenondé Porá, antes denominada aldeia da Barragem. O encanto pelos povos indígenas surgiu nas aulas de biogeografia, onde compreendíamos que o estudo da vegetação não se fazia sem o estudo das populações que a habitam, e que dão sentido aos territórios, não como palco das sociedades, mas como uma extensão da vida dessas.

O contato com diferentes povos indígenas do Brasil e do México, em trabalhos voluntários, possibilitou compreender melhor que os contextos nos quais estão inseridos os grupos influenciam muito no território e nas espacialidades das comunidades, que estão condicionadas às situações e contextos territoriais diversas. Entre 2011 e 2012 foram feitas visitas à comunidade Tekoá Tenondé Porã, mas que não serão relatadas em sua integridade. Serão referenciados alguns trabalhos de campo que foram estratégicos para o desenvolvimento da pesquisa anterior e da atual.

Em 2011, com o propósito de realizar o primeiro contato com a comunidade Guarani conhecida como Tekoá Tenondé Porã, para a realização do trabalho de conclusão de curso de graduação em Geografia, fui até uma localidade afastada da mancha urbana de São Paulo, cerca de 50 quilômetros do centro de São Paulo, em uma das regiões apontadas de baixo IDH, segundo dados relativos à renda, educação e saúde. Atualmente, o município de São Paulo tem 3 Terras indígenas Guarani Mbyá demarcadas, como é possível visualizar no mapa 1:

\footnotetext{
${ }^{2}$ Palestra proferida por Guarani Mbyá em 03/06/2016.

${ }^{3}$ Nome dado aos não índios.
} 
Figura 4: MAPA DE LOCALIZAÇÃO PONTUAL DAS ALDEIAS GUARANI DE SÃO PAULO

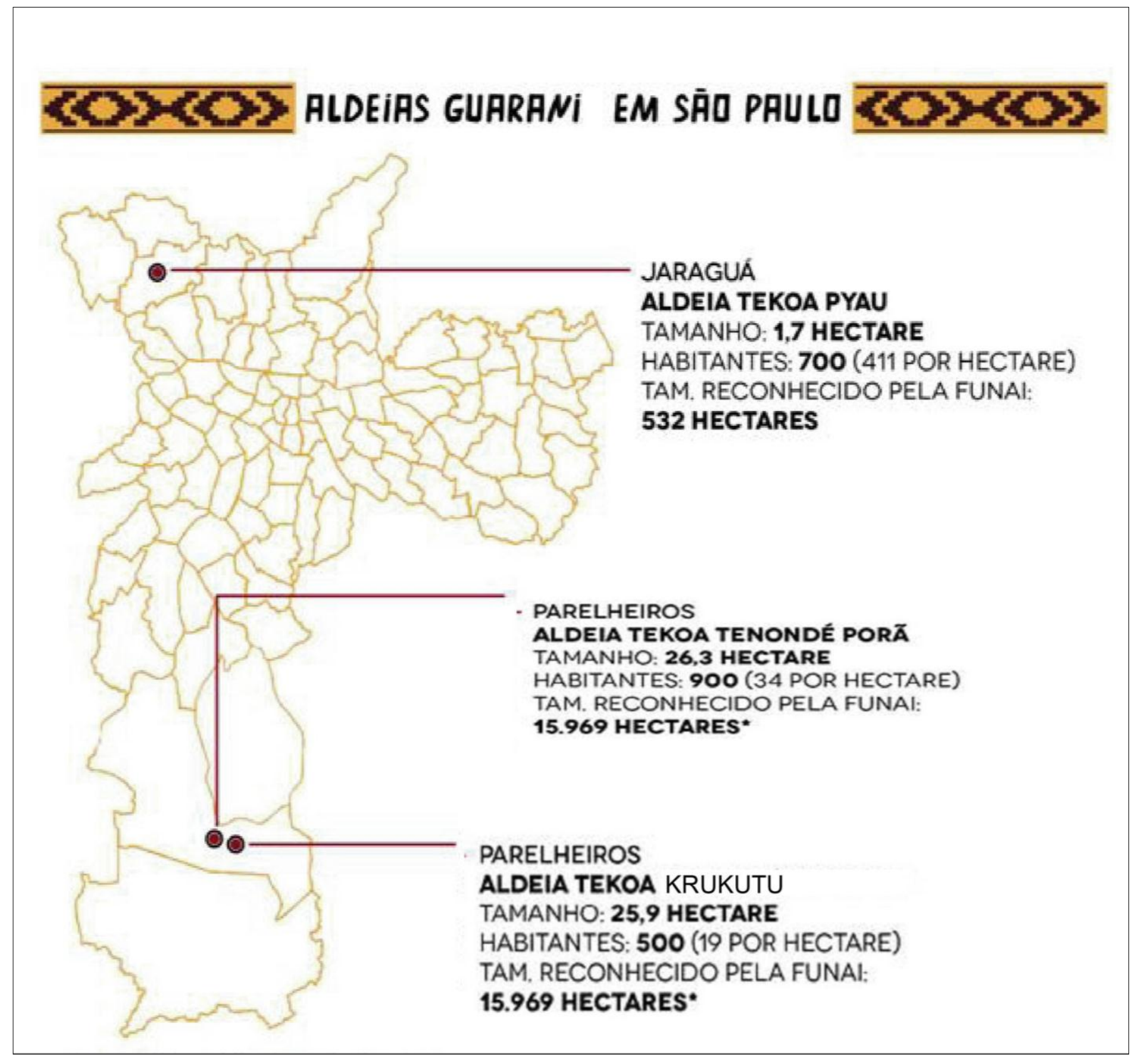

Fonte: Adaptado de www.brasildefato.com.br: Rafael Stedile (2014). 
Nas diversas oportunidades de contato com a comunidade, foi possível constatar que a fragmentação dos Guarani em pequenas parcelas de Terras ${ }^{4}$ demarcadas, não representam um território Guarani. Além disso, foi possível averiguar que, segundo os Guarani, o território pressupõe a junção de diversas comunidades em um mesmo território contínuo. Isso permitiria a circulação dos Guarani entre as diferentes aldeias situadas na região da Serra do Mar, possibilitando o desenvolvimento do modo de ser tradicional Guarani, o nhadereko. ${ }^{5}$

Ao adentrar a comunidade Tekoá Tenondé Porá, com conhecimento prévio sobre esses grupos, abordou-se um grupo de Guarani e se consultou com quem poderia conversar mais sobre a organização da comunidade. Os diversos Guarani, que estavam subindo a rua principal de Terra que corta a parte central do núcleo habitacional da comunidade, apontaram para a casa de Lizio, cuja função era receber os "juruás" e estabelecer diálogos. Este primeiro contato teve como intuito colher informações para desenvolver o trabalho de conclusão de curso de graduação em Geografia, realizado sobre a orientação da Luciene Cristina Risso ${ }^{6}$.

A conversa com Lazio durou o tempo necessário até que ele esclarecesse o funcionamento da comunidade, as dificuldades, as necessidades e os processos de negociação da comunidade com a FUNAI. Segundo Lizio (2011), a questão da ampliação da Terra demarcada da comunidade é um dos problemas mais difíceis para a comunidade. Grandes obras públicas para o município de São Paulo foram construídas e tiveram grande influência no território da comunidade, a construção do rodoanel Mario Covas, a construção de linhas de transmissão e o próprio

\footnotetext{
4 "As Terras tradicionalmente ocupadas pelos índios (...) são Terras públicas da União, constitucionalmente vinculadas aos direitos originários dos índios sobre elas, para sua habitação permanente, e à preservação dos recursos ambientais necessários ao seu bem-estar e às necessidades de sua reprodução física e cultural, segundo seus usos, costumes e tradições" SILVA, José Afonso da. Curso de Direito Constitucional Positivo. São Paulo: Malheiros, 2005, p. 275.

${ }^{5} \mathrm{O}$ trabalho anteriormente desenvolvido de conclusão de curso de graduação em geografia na Universidade Estadual Paulista (2014) tinha como objeto de investigação os aspectos geográficos que davam sentido aos conceitos de Terra, território e territorialidade para a Comunidade indígena Guarani Tekoá Tenondé Porã por meio de entrevistas e observações de campo.

${ }^{6}$ Professora Doutora da Universidade Estadual "Júlio de Mesquita Filho".
} 
espraiamento da mancha urbana atingem diretamente a comunidade. Segundo ele, naquele momento havia duas propostas com relação ao território da comunidade: a compra de outra Terra ou a ampliação da Terra atualmente demarcada. A primeira proposta foi descartada devido aos problemas que isso causaria para a comunidade, pois não seria simples adquirir outra Terra para a comunidade, pois a área atualmente ocupada tem grande representatividade na cultura dos Guarani, o que faz com que essa área seja insubstituível por outra.

A proposta de ampliação da Terra demarcada, que hoje corresponde somente ao núcleo habitacional, a partir da agregação da área de caça, pesca e coleta configura-se como a principal pauta de luta e resistência dos Guarani das comunidades Guarani das Terras indígenas da Serra do Mar, dentre elas a Terra Tenondé Porã.

A agricultura, que poderia ser desenvolvida após a ampliação da Terra, por exemplo, é extremamente importante, pois permitiria o desenvolvimento do modo de ser tradicional dos povos Guarani, o chamado nhadereko ${ }^{7}$. Com a prática da agricultura seria garantida maior autonomia e a manutenção básica de alimentos tradicionais à comunidade e aos rituais ligados aos ciclos de colheita e plantio.

Em 2013, em outra oportunidade de visita à comunidade, descobri que Lazio não morava mais na aldeia e que ele estava em Santa Catarina, em outra aldeia. Nessa oportunidade- fui recebida por Osmar e comecei a indagá-lo sobre diversas questões da comunidade, agora já com um questionário qualitativo estruturado, focado na questão do território Guarani, e com um arcabouço teórico muito mais aprofundado sobre a cultura Guarani e sua relação com o território que habita.

Osmar era professor da escola estadual da comunidade e nos conduziu até ela ${ }^{8}$. Ao chegar nos corredores da escola, ele apontou para uma imagem de satélite que estava pendurada na parede e assinalou o que ele considera como território Guarani. Ele fez questão de frisar que o núcleo habitacional que hoje está demarcado não pode ser considerado um território Guarani, isso ocorreria quando

\footnotetext{
${ }^{7}$ Modo de vida tradicional que será abordado nos capítulos da dissertação.

${ }^{8}$ Nesta oportunidade o trabalho de campo foi realizado acompanhada com mais uma pessoa.
} 
efetivamente as comunidades tivessem livre circulação entre as aldeias da Serra do Mar, com área destinada para pesca, caça e coleta.

No mesmo dia também foi possível conversar com Adriano sobre as questões levantadas anteriormente. Adriano é coordenador pedagógico da escola municipal da comunidade e um dos responsáveis pelo recebimento de pesquisadores. Ele então tornou-se o principal interlocutor, visto que Lazio e Osmar mudaram de aldeia. Osmar agora habita outra aldeia Guarani "mbyá", localizada também em São Paulo. Lazio estava em uma comunidade Guarani de Santa Catarina. É importante frisar que, inicialmente, esses dois interlocutores foram extremamente importantes para o desenvolvimento desta pesquisa, contribuindo de forma decisiva nas ideias e percepções finais aqui apresentadas. Por isso, essa retrospectiva dos encontros e desencontros nos diversos trabalhos de campo na comunidade.

Entre 2010 e 2013 ocorreram diversas visitas à comunidade que não serão abordadas detalhadamente. No entanto, foram fundamentais para estabelecer contatos futuros com a comunidade, o que encorajou a realização da pesquisa atual.

Essa "relativa" abertura da comunidade para realizar pesquisa e trabalhos diversos é dosada com uma medida de fechamento. Cada comunidade e etnia ${ }^{9}$ relacionam-se de diferentes formas com os "brancos"10. Uma das estratégias de manutenção da cultura é justamente 0 afastamento relativo do outro, mesmo assumindo que esse "outro" tem elementos importantes para trocas culturais. A comunidade Tenondé Porã costuma receber diversos pesquisadores e turistas, pois o acesso à comunidade é relativamente tranquilo, ela está cerca de $40 \mathrm{~km}$ do centro da cidade de São Paulo.

O primeiro contato com a comunidade com o intuito de investigar as representações do que eles consideram como território, foi estabelecido com Adriano, no início de 2014, antes do início oficial do mestrado. De nenhum modo o

\footnotetext{
9 "Termo utilizado para designar as características culturais próprias de um grupo, como língua e os costumes". In: Dicionário de conceitos históricos - Kalina Vanderlei Silva e Maciel Henrique Silva Ed. Contexto - São Paulo; 2006.

${ }^{10}$ Não índios
} 
objetivo foi classificar, em grau de importância dentro da comunidade, as pessoas que iríamos entrevistar ou manter contato. Penso que muitos pesquisadores priorizam falar com o cacique, ou lideranças mais antigas dentro da comunidade. Neste caso a escolha de quais seriam os interlocutores ocorreu de forma aleatória, sem atentar-se à questão da posição social que os indivíduos ocupam na comunidade. Atualmente, há um engajamento dos jovens na luta pela proteção dos territórios, há diversas oficinas e cursos ministrados por antropólogos que focam a questão da regularização de Terras. Portanto, há uma consciência e uma fala coletiva quanto aos discursos relativos à necessidade de acesso aos direitos garantidos constitucionalmente.

A experiência com as comunidades levou a pensar diferente a cartografia e o próprio ensino da cartografia, visto que hoje a apreensão de mapa que está naturalizada no imaginário da sociedade é o mapa que contém localização exata dos objetos ${ }^{11}$ (FONSECA, 2004). Para os Guarani- a representação não está restrita a localização, tendo eles uma diversidade imagética muito variada e interessante para ser compreendida, tema que é transversal a todos os capítulos dessa dissertação.

Com as representações produzidas pela comunidade, e após contato com autores que trabalham o mapa como uma construção social (HARLEY, 1989), constatou-se que a cartografia produzida pela comunidade era em sua essência totalmente diferente, e que seria necessário desconstruir muitas ideias e teorias. A ideia de mapa como mera ilustração do texto escrito percorreu toda vida acadêmica e o desenvolvimento do trabalho final de graduação, já no mestrado houve um crescimento intelectual que permitiu constatar que as representações são fundamentais na compreensão de conceitos espaciais, revelando um leque de possibilidades de interpretação muito mais amplo e diverso no campo da geografia.

As concepções sobre o tema são fruto de convivência e estudo sob a questão indígena. Os territórios indígenas são necessários para frear os processos de genocídio e etnocídio levados a cabo sobre o discurso de progresso

${ }^{11}$ Ideia central da tese de doutorado de Fernanda Padovesi Fonseca (2004). 
nacional (CLASTRES, 2010). Portanto, o território é imprescindível para a reprodução cultural, não se pensa essa cultura sem seu território.

Constatou-se também que o trabalho com representações é fundamental quando se quer entender as espacialidades de grupos, ou mesmo, elementos relacionados à visão de mundo, pois trazem questões que são centrais nesse tipo de tema. Entender a cartografia das comunidades indígenas significa explorar a diversidade de possibilidades de diálogo a partir de linguagens diversas.

O objetivo em desenvolver esta pesquisa de mestrado sobre o território e as espacialidades indígenas Guarani, também tem como intuito contribuir para a discussão sobre os instrumentos de diálogo possíveis quando se pretende entender a concepção do outro sobre território. Ao mesmo tempo, deriva da necessidade de fortalecer perspectivas que contribuam para a preservação e valorização dos grupos indígenas que resistem ao crescente extermínio de seus territórios e, consequentemente, de sua cultura. Atrelado a essas questões também está em jogo a manutenção dos remanescentes florestais contidos nas Terras indígenas, questão não aprofundada, mas que merece maior atenção em outras pesquisas por sua relevância. 
INTRODUÇÃO

FONTE: Ronaldo Karai, 29 anos, realizado em 17/09/2015.

No município de São Paulo há três Terras indígenas homologadas, sendo elas: Tenondé Porá e Krukutu, no distrito de Parelheiros, e Jaraguá, na Zona 
Noroeste. O conjunto dessas Terras abriga cerca de 3000 índios da etnia Guarani Mbya.

A comunidade Tenondé Porã, a área de estudo desta pesquisa, possui somente o núcleo habitacional demarcado. Há a reivindicação da ampliação da Terra, o que propiciaria a união de 5 Terras indígenas, permitindo a circulação livre entre as Terras: Itaóca, Aguapeú, Boa Vista e Tenondé Porã, denominando esta área de fragmento do que seria o Território Guarani da Serra do Mar, segundo Adriano (2016). Portanto, essa ampliação abrangerá somente um fragmento, não o território em sua totalidade, pois este abarca áreas de outros países, como é possível observar no mapa da presença Guarani na América do Sul (figura 15).

A Terra atualmente demarcada da comunidade Tenondé Porã, local de desenvolvimento desta pesquisa, possui aproximadamente 15.970 hectares e está localizada na região do extremo sul da periferia de São Paulo, dentro do município de São Paulo. A área demarcada contém somente o núcleo habitacional, excluindo a área fundamental para caça, pesca e coleta.

A Terra Indígena Tenondé Porã, após homologação, será composta por 6 aldeias, sendo elas: Barragem e Krukutu, situadas às margens da Represa Billings, a aldeia Kalypete está situada na Evangelista de Souza, a aldeia Yre Xakã em Marsilac, às margens do rio Capivari. Finalmente, a Aldeia Karay Rexakã e Guyrapaju, do outro lado da represa Billings, área situada no município de São Bernardo do Campo, constituindo essas aldeias permanentes e transitórias uma Terra de 16 mil hectares. No figura 7, é possível visualizar a área de delimitação ampliada da Terra indígena Tenondé Porá, proposta que foi elaborada pela comunidade e pela FUNAI a partir de estudos antropológicos de aproximadamente 20 anos. 
Figura 5: MAPA DE LOCALIZAÇÃO DE TERRAS INDÍGENAS EM SP.

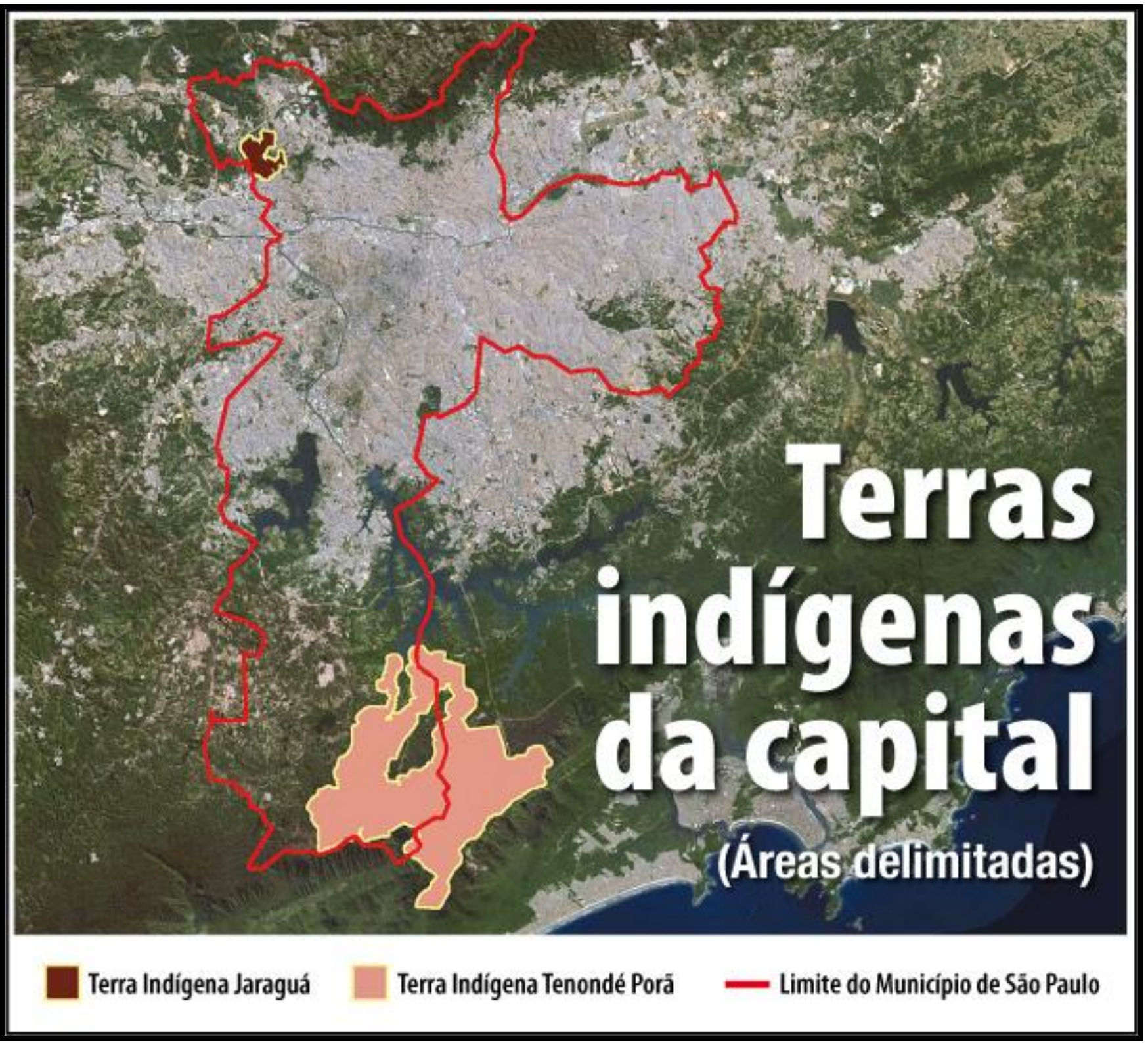

Fonte: Centro de Trabalho indigenista (2015). 
Figura 6: MAPA DO FRAGMENTO DO TERRITÓRIO GUARANI DA SERRA DO MAR

\section{Território Guarani da Serra do Mar}

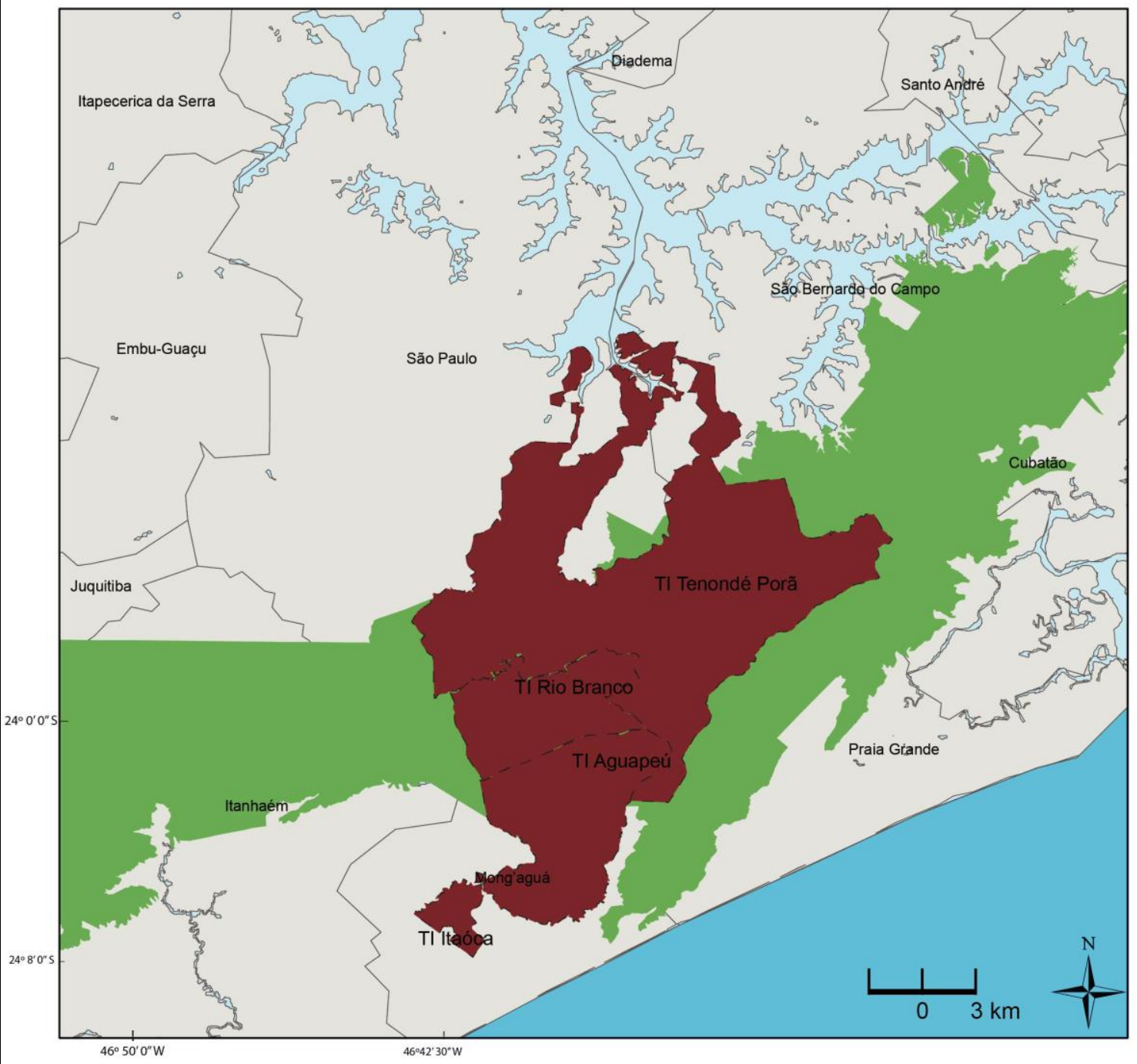

Território Guarani

Parque Estadual da Serra do Mar Rios

Concepção do mapa:

Comunidade Tekoá Tenondé Porã.

Elaborado em ArcGIS 10.1.

Shapefiles: IBAMA; FUNAI.

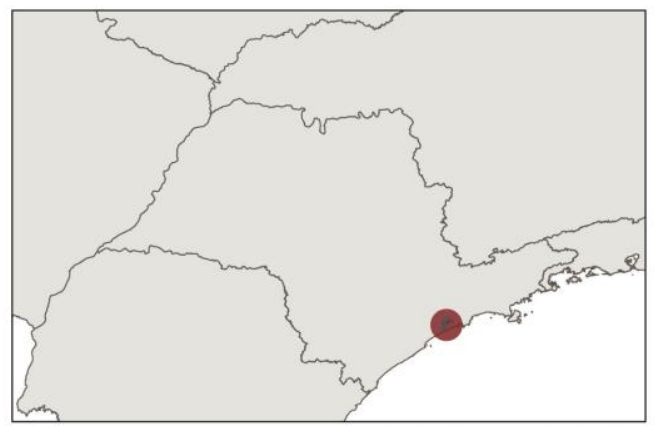

Fonte: Elaborado pelo autor (2016). 
Figura 7: MAPA DA TERRA INDÍGENA TENONDÉ PORÃ

\section{Terra Indígena Tenondé Porã}

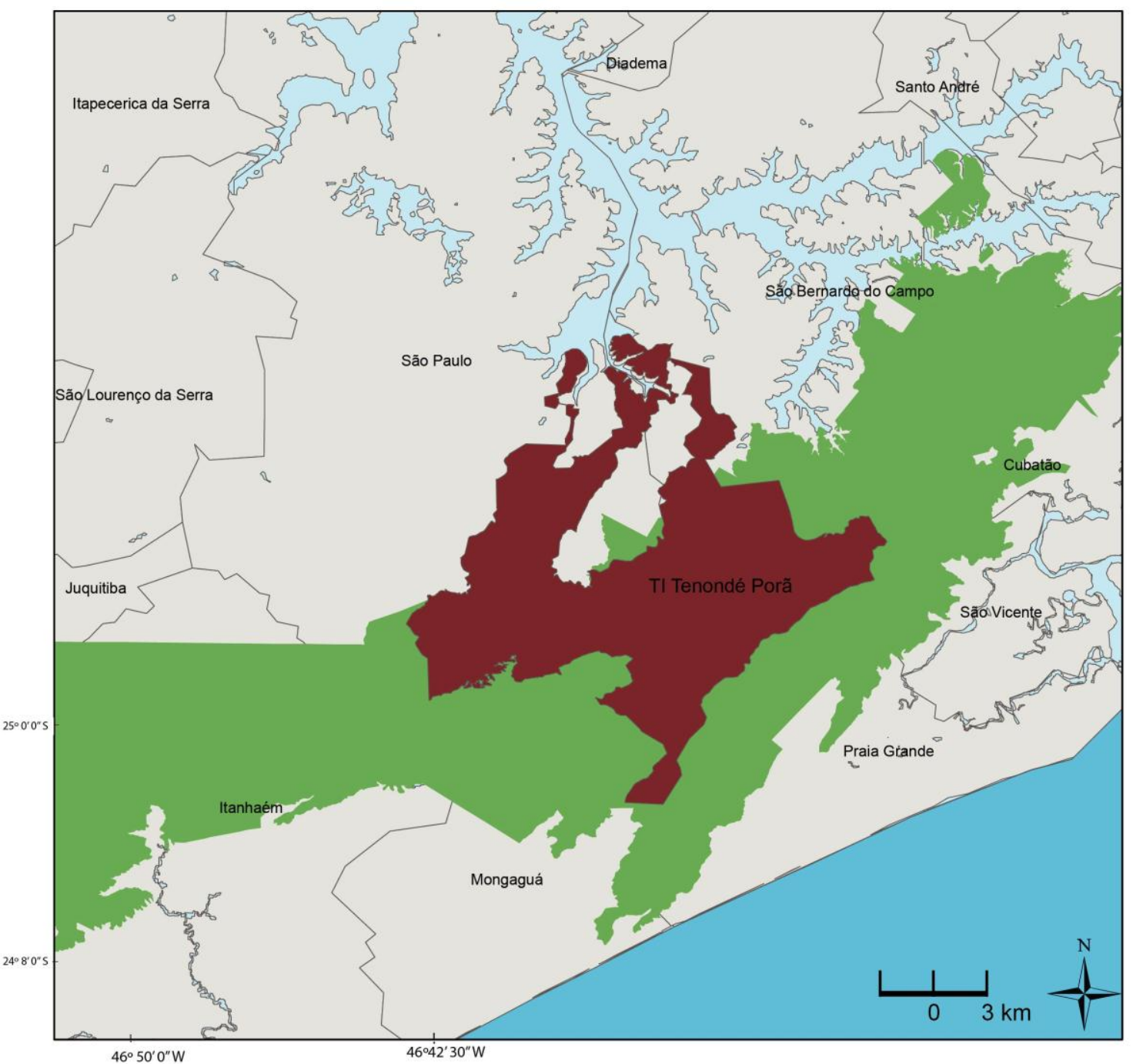

Terra Indígena Tenondé Porã

Parque Estadual da Serra do Mar

Rios

Concepção do mapa:

Comunidade Tekoá Tenondé Porã.

Elaborado em: ArcGIS 10.1.

Shapefiles: IBAMA; FUNAI.

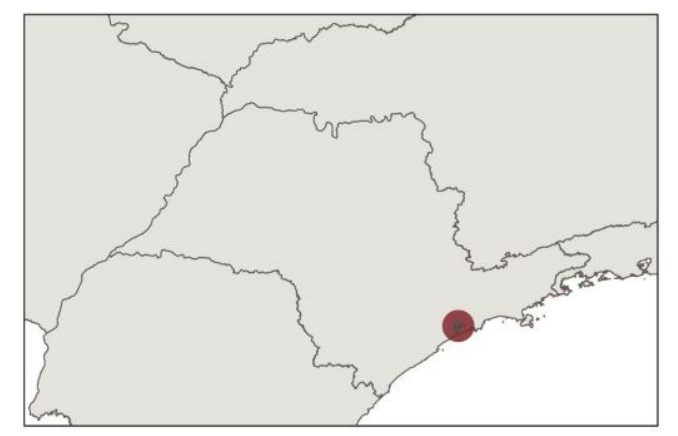

Fonte: Elaborado pelo autor (2016). 
Figura 8: MAPA DA ÁREA HOMOLOGADA DA TERRA TENONDÉ PORÃ

\section{Núcleo Habitacional Tenondé Porã - Barragem Terra Indígena Tenondé Porã}

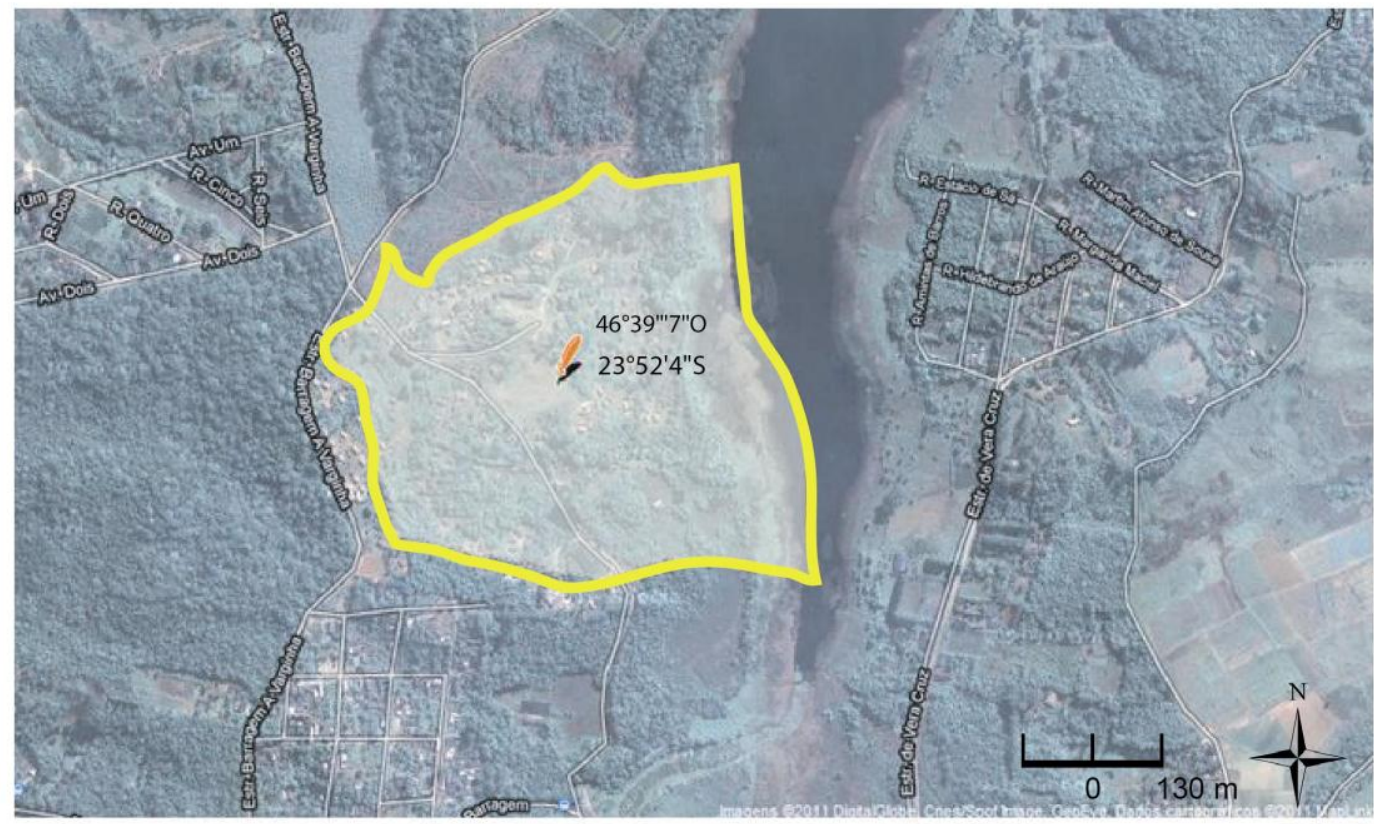

Etnia- Guarani Mbyá

Área Homologada:

26 hectares

$\square$ Área Reivindicada:

16 mil hectares

Fonte: google earth;

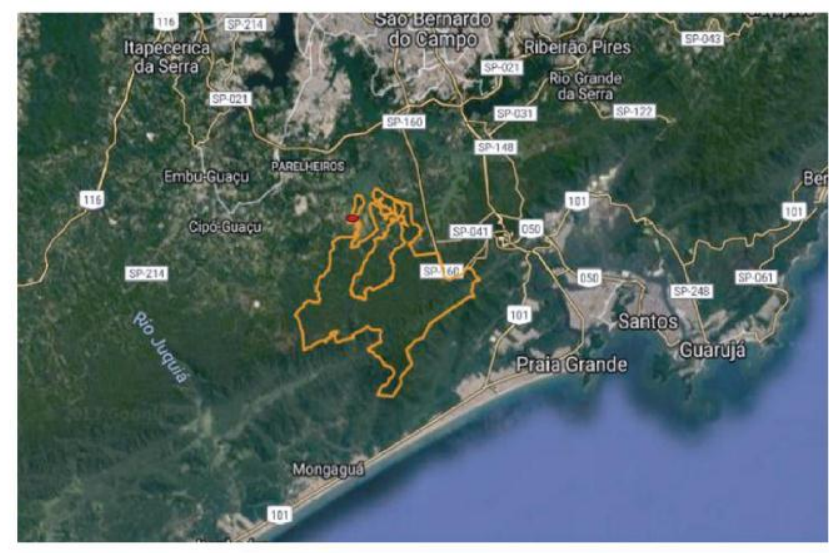
guarani.map.as

Fonte: Elaborado pelo autor (2016). 
Figura 9: MAPA DAS ALDEIAS DA TERRA INDÍGENA TENONDÉ PORÃ

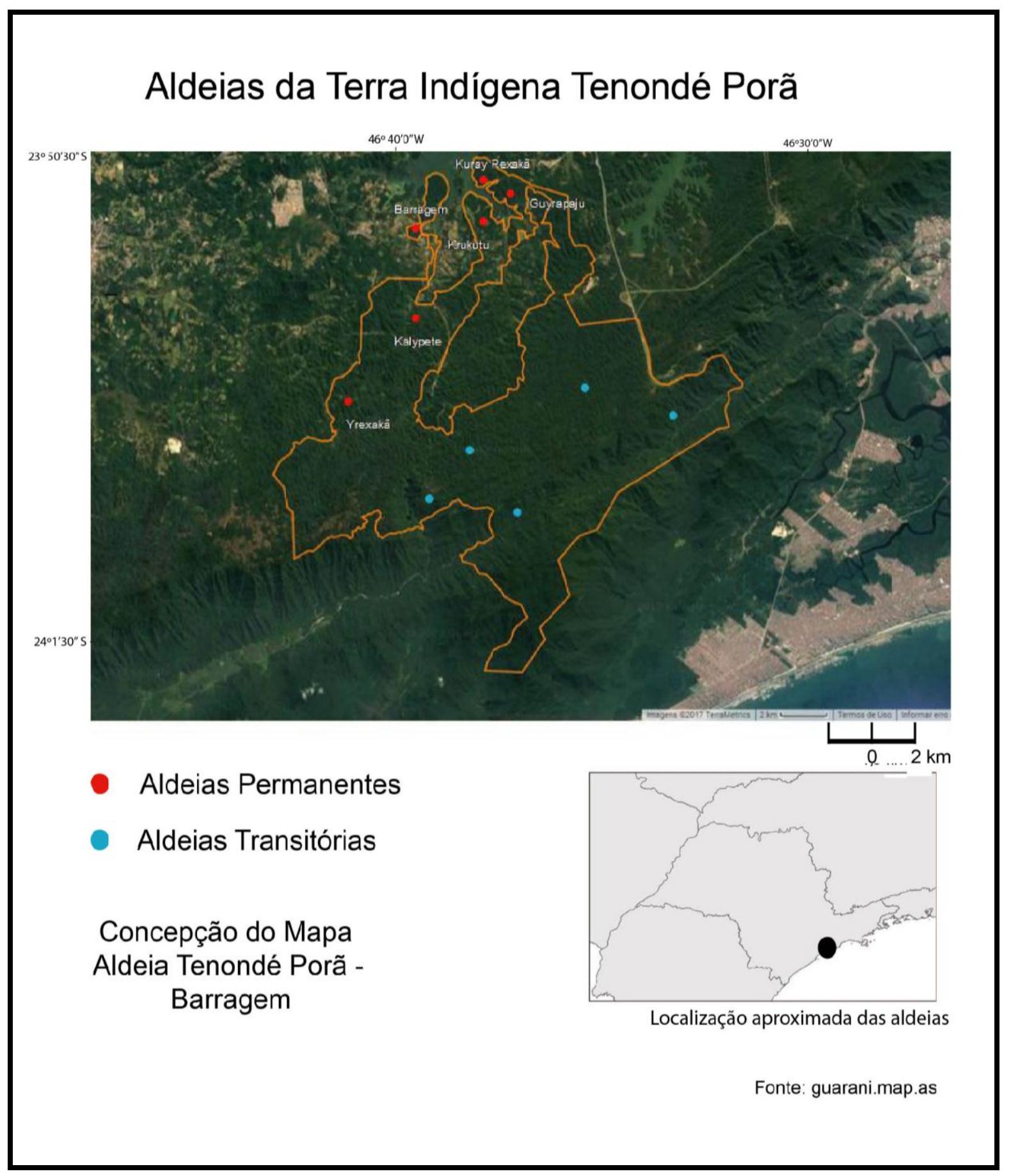

Fonte: Elaborado pelo autor (2016). 
Figura 10: Mapa de sobreposições

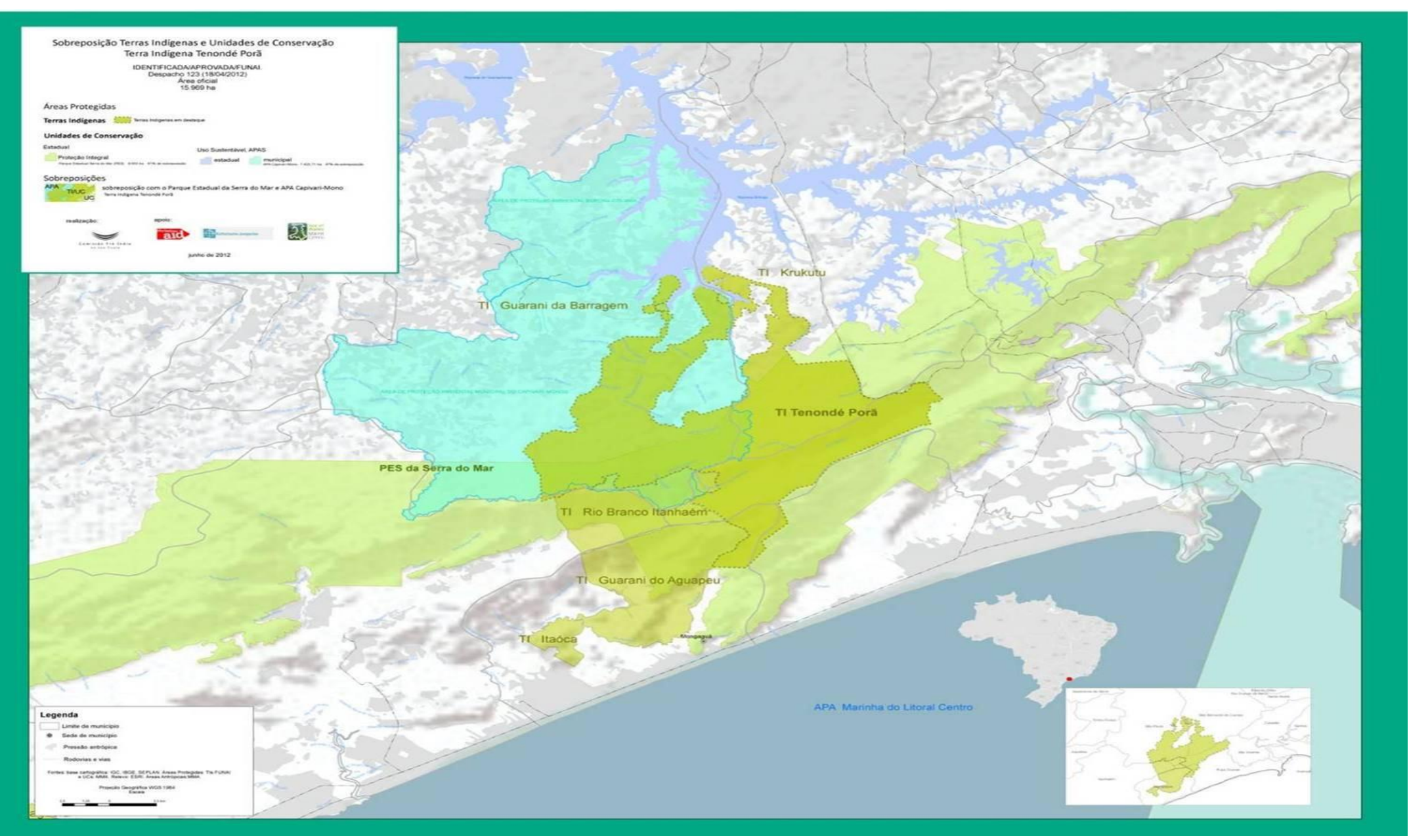

Fonte: Comissão pró índio (2012). 
De acordo com os mapas explanadas, quando se fala do fragmento do território Guarani da Serra do Mar, tem-se como referência a unificação de seis Terras indígenas, localizadas nos municípios de São Paulo, Mongaguá, São Vicente e São Bernardo do Campo, que constituem um fragmento do que os Guarani consideram seu território, dentro do contexto dessa pesquisa.

Quando se fala em Terra indígena se tem como referência a utilização da terminologia empregada pela FUNAI para denominar a área indígena. A aldeia é a denominação utilizada para fazer referência ao núcleo habitacional, e pode ser entendida também tekoá. O território de ocupação tradicional (yvy rupa) transcende as fronteiras nacionais e internacionais, pois é um território mais amplo. Esses recortes espaciais ficam claros quando observado os mapas anteriores ( figuras 5, 6, 7, 8, e 9).

Os fragmentos de Terras indígenas da Serra do Mar são denominados de Tenondé Porã, Aguapeú, Itaóca, Rio Branco que totalizam uma área de aproximadamente 26.000 hectares formando um território contíguo e contínuo que permitiria o desenvolvimento cultural dos povos Guarani da Serra do Mar, segundo o relatório de ampliação e demarcação da Terra desenvolvido pela FUNAI (2012) ${ }^{12}$ e publicado no Diário Oficial de São Paulo. Dentro do constatado em campo, essa ampliação, de fato, contribuiria para interligar as comunidades, facilitaria as trocas, a circulação e o desenvolvimento do modo de ser tradicional Guarani. Além de incorporar o território destinado à caça, pesca e coleta de recursos da cultura Guarani.

Há a sobreposição da Terra indígena Tenondé Porá com o Parque Estadual da Serra do Mar, o que corresponde a $61 \%$, aproximadamente 10 mil hectares ${ }^{13}$. Tem-se, também, a sobreposição da Terra indígena Tenondé Porã com 149 propriedades privadas, tema que será abordado mais adiante. Também há a sobreposição da comunidade com a APA Capivari Monos.

A comunidade indígena é composta, sobretudo por crianças e jovens, e está em constante crescimento populacional, como é possível observar no gráfico

\footnotetext{
12 Diário Oficial da União, 2012, p. 20.

13 Informação retirada de www.Terrasindigenas.org.br; acesso em 25/08/2017.
} 
da figura 11, fato que justifica a necessidade de ampliação da Terra, devido à necessidade de uma área maior para o desenvolvimento do modo de ser tradicional Guarani. A Terra Indígena Tenondé Porã tem aproximadamente 1400 moradores, somando somente as aldeias Barragem e Krukutu.

\section{FIGURA 11: DADOS DEMOGRÁFICOS DA TERRA INDÍGENA TEKOÁ TENONDÉ PORÃ}

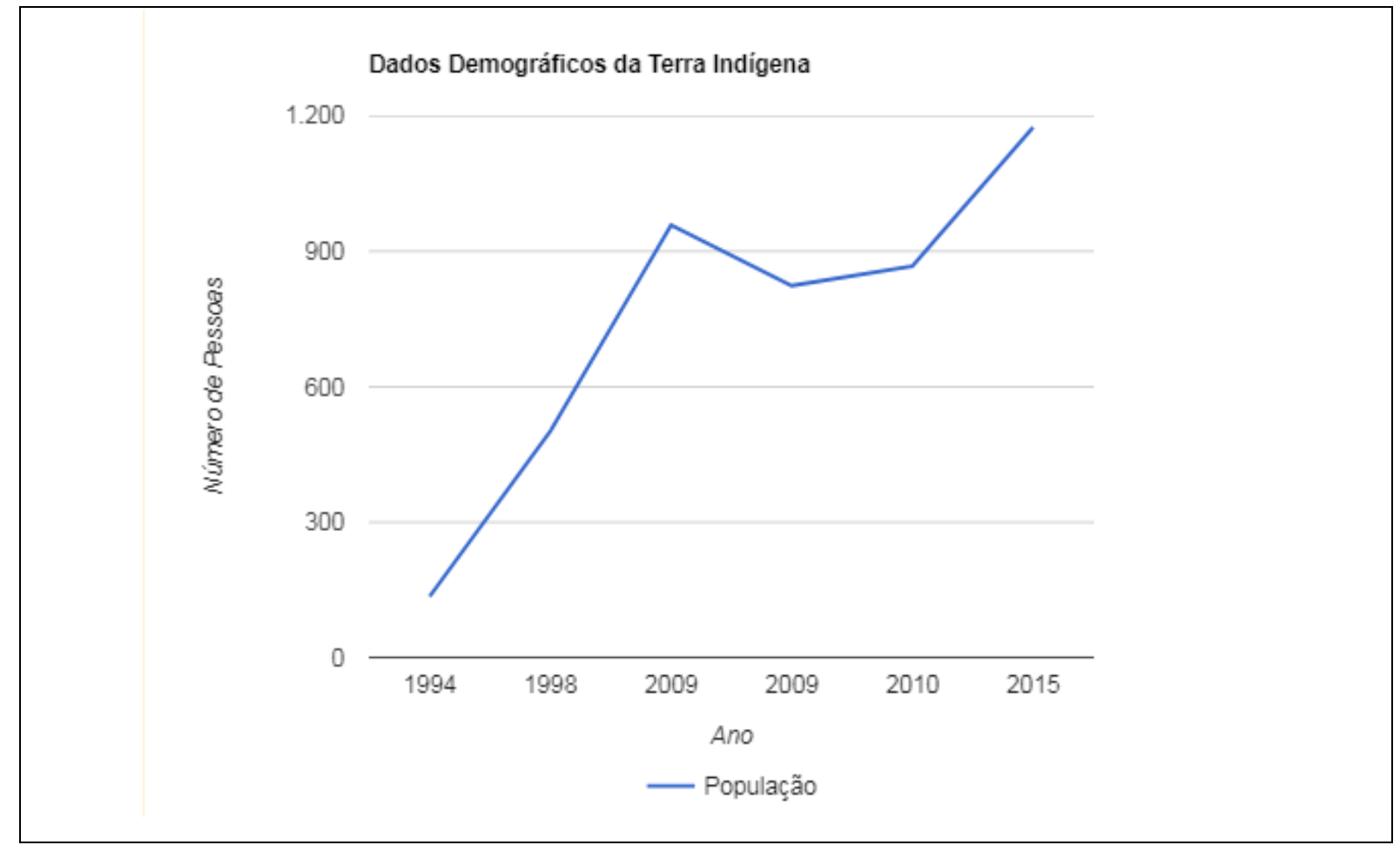

Fonte: terrasindígenas.org.br

Os Guarani passaram por dois processos de regularização de suas Terras, um em 1987 e outro em iniciado em 2012-2013. O primeiro processo de regularização deu origem à demarcação da Terra indígena Tenondé Porã, área que só corresponde ao núcleo habitacional, enquanto que o segundo processo, como exposto anteriormente, ainda está em andamento, e falta somente a homologação pela presidência da República para sua consolidação jurídica.

No primeiro momento, com a demarcação somente do núcleo habitacional, houve a expulsos dos Guarani, ou seja, a exclusão do território destinado à caça, 
pesca e coleta ${ }^{14}$. No entanto, há um movimento de retomada de muitas territórios para a garantia da regularização da Terra Indígena, é o caso das novas aldeias permanentes instaladas nas áreas que eram somente transitórias.

A FUNAl elaborou os estudos de reconhecimento e identificação de diversas Terras Indígenas, dentre elas a Terra indígena Tenondé Porá, que teve o relatório aprovado em 2012, e em 2016 declarada de posse permanente e de usufruto exclusivo dos povos Guarani.

Em meados de novembro de 2013 ocorreram ataques à Tekoá Kalipety da Terra Indígena Tenondé Porá, de autoria não identificada e com disparos de arma de fogo lançados em direção aos Guarani ${ }^{15}$, fato que ocorre em meio ao processo de retomada dos territórios da região para reforçar a necessidade de homologação da $\mathrm{TI}^{16}$ Tenondé Porã.

O conceito de território, tão diverso em seus contextos específicos de apropriação, apresenta diversas definições. Apropria-se aqui a concepção que o território é dotado de múltiplos significados, materiais e imateriais, o território como fruto das relações de poder entre indivíduos, grupos de indivíduos, e instituições como coloca Raffestin (1993). Essas relações de poder, por meio de diferentes atores, constroem o território de acordo com o interesse de cada grupo.

A definição utilizada pelos órgãos públicos para delimitar e demarcar territórios destinadas às populações tradicionais é Terra, previsto no texto da Constituição Federal de 1988, que garante aos povos indígenas o direito de reprodução cultural ${ }^{17}$. No entanto, essa definição é problemática, principalmente se ela considera somente a demarcação do núcleo habitacional, como é o caso da comunidade Tenondé Porã, excluindo o território destinado à caça, pesca e coleta de materiais.

Em contrapartida, para os povos indígenas, a definição de um território é muito mais complexa, cada etnia pode ter uma definição diferente de território.

\footnotetext{
${ }^{14}$ Ideia presente na tese de Camila Salles Faria (2017)

${ }_{15}^{15}$ Informação retirada do site www.esquerdaonline.com, acesso em 17/11/2018.

${ }^{16}$ Terra Indígena.

17 São reconhecidas aos índios sua organização social, costumes, línguas, crenças e tradições, e os direitos originários sobre as Terras que tradicionalmente ocupam, competindo à União demarcálas, proteger e fazer respeitar todos os seus bens.
} 
Para os povos Guarani, o território é muito amplo e bem divergente da concepção de território delimitado por limites, a fronteira aqui entra como uma ação sobre o território que os Guarani não concebem da mesma forma que a sociedade contemporânea.

Desse modo, esta pesquisa de mestrado questiona se é possível apreender o território do outro, nesse caso o Guarani, por meio da produção de representações diversas. Ou ainda, saber como esse outro concebe e é capaz de representar o seu próprio território material e simbólico. Portanto, constituindo-se as representações do território Guarani objeto de estudo dessa pesquisa.

No caso dos povos indígenas, a concepção de território deve ser singularizada, como observou Gallois (2004). Isso se deve às condições póscoloniais as quais esses grupos são submetidos, os limites e fronteiras passam a se tornar uma realidade necessária.

A mobilidade constante dos indígenas, constatada na literatura (Ladeira, 2008) e observada por meio de anos de contato com a comunidade, demonstrou que os territórios indígenas são ligados por meio de redes de parentela, pois estabelecem fluxos constantes de pessoas e de objetos, aspectos materiais como simbólicos. A circulação e a mobilidade dos Guarani também se fundamenta na parentela ${ }^{18}$, fato que reforça ainda mais a ideia de território em redes. Esse aspecto já tinha sido observado por Ladeira (2008, p.194) em seus trabalhos junto as comunidade Guarani.

O modo de vida Guarani - mbya define uma dinâmica de ocupação imbricada nas redes de parentesco, e esta associação é a base de sustentação da sociedade. A mobilidade é, pois, inerente a esse sistema, assim como as relações de parentesco podem ser referências aos movimentos migratórios.

As comunidades indígenas estabelecem redes de trocas de mercadorias e saberes, articulações políticas e culturais, que transcendem os limites estabelecidos e as distâncias quilométricas entre as aldeias.

${ }^{18}$ Rede de parentesco. 
Ao analisar as representações desse território Guarani, algumas questões, bem como conceitos, são fundamentais para compreender a sua constituição e fragmentação, tais como: fronteira, distância, território, espaço, redes e nós. A observação a partir do ponto de vista zenital, frontal e abstrato que cada indivíduo pode ter em relação ao território, as representações coletivas e individuais e seus contextos sociais serão discutidos nesta pesquisa.

A fragmentação dos territórios dos povos indígenas representam não só a supressão da vegetação originária, em muitos casos, mas, também, o etnocídio, processo relacionado ao extermínio das culturas indígenas assinalado por Clastres (2010). Essa questão foi levantada em outros trabalhos que tinham como foco o território e a conservação da natureza (GOMIDE, 2008).

Desse modo, a questão central abordada aqui é a fragmentação do território Guarani como um impeditivo à sobrevivência dessas comunidades. A discussão empreendida na dissertação busca verificar como esta questão está presente, ou não, nas representações produzidas pela comunidade.

A ampliação e a unificação do território, de forma a produzir uma extensão contínua e contígua de Terra aos Guarani permitiria a valorização e a reconstrução do seu modo de vida tradicional (nhadereko). Assim, algumas premissas podem ser elencadas que nos dimensionam o contexto daquela comunidade

- O território da Comunidade Guarani Tekoá Tenondé Porã deve ser contínuo e contíguo;

- Existem problemas relacionados à fragmentação do Território Guarani em Terras;

- É possível identificar conexões entre as Terras Guarani fragmentadas da Serra do Mar;

- É possível apreender o território do outro a partir de suas representações. 
- Nas representações há indicações de que o modo de ser tradicional Guarani está impedido de ser desenvolvido devido a fragmentação do seu território.

A partir dessas questões foram delineados os objetivos gerais e específicos dessa pesquisa, bem como a seguinte hipótese:

- Os Guarani produzem representações espaciais que permitiriam compreender suas concepções de território e também as questões que envolvem a fragmentação desse território e a consequente interdição do seu modo de vida tradicional. 


\section{METODOLOGIA}

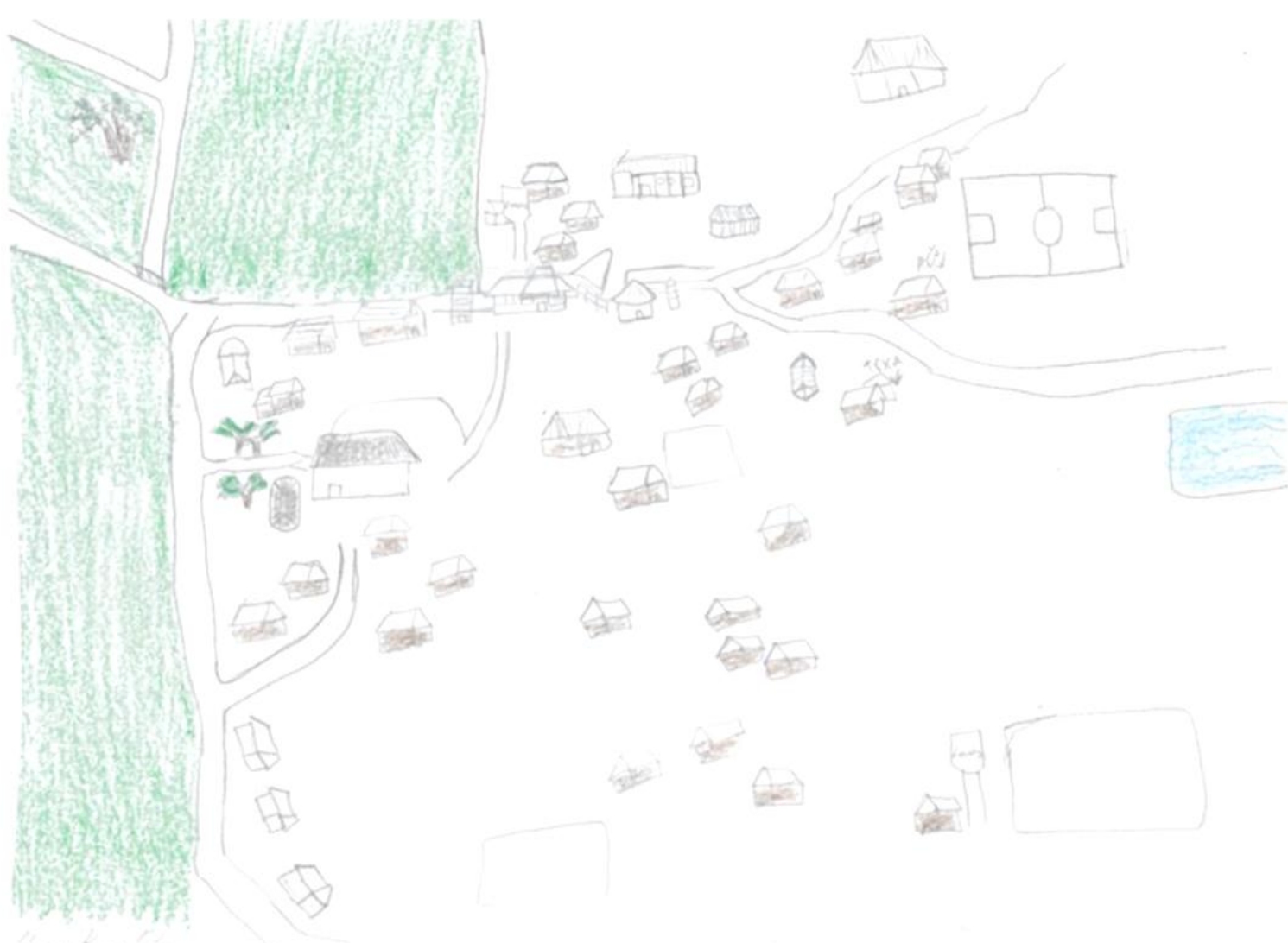

Fonte: Adriano Verissimo, 30 anos, realizado em 17/09/2015. 
A metodologia de trabalho foi estruturada a partir da convivência e do diálogo com a comunidade Guarani Tekoá Tenondé Porã, experiência que não está limitada ao tempo oficial de início desta pesquisa, como abordado na apresentação. A possibilidade de sua realização só ocorreu porque, anterior ao seu início, já havia ocorrido diversos contatos com a comunidade, o que possibilitou a abertura para trocas de informação e conhecimentos.

Para responder às questões centrais dessa pesquisa, a metodologia adotada considerou a análise de entrevistas formais e informais coletadas entre 2011 e 2017, representações desenvolvidas em diferentes experiências, o resumo do estudo antropológico desenvolvido pela FUNAI (relatório de demarcação) ${ }^{19}$, revisão bibliográfica e observação de campo. Para tanto, levou-se em conta o que já havia sido produzido em relação às Terras e território Guarani, bem como quais lacunas permaneciam em aberto quando se pretende entender ou mesmo definir o território do outro, optando em utilizar as diferentes linguagens (oral, escrita e visual) para sua compreensão.

Os resultados apresentados nesta pesquisa, embora convergentes com os resultados publicados pelo relatório da FUNAI, em relação a metodologia empregadas são diferentes. Os objetivos do relatório da FUNAI e dessa pesquisa são diferentes, pois a FUNAI trabalha com a cartografia hegemônica do Estado. $O$ material da FUNAI foi mais uma fonte de pesquisa necessária e indispensável para entender a área de estudo, bem como experiências pretéritas que conduziram a entender os recortes geográficos apresentados.

Atribui-se aqui à representação a função de levantar questões, quer dizer, ela não é um reforço de texto construído a partir da memória oral, mas torna-se protagonista, tendo um papel fundamental, pois estabelece as principais questões que serão discutidas dentro de uma perspectiva cartográfica.

As representações produzidas nos trabalhos de campo pelos Guarani da Comunidade Indígena Tekoá Tenondé Porã, foram analisadas à luz das experiências constituídas nos diversos trabalhos de campo, na observação e na

\footnotetext{
${ }^{19}$ Resumo publicado no Diário Oficial de 2012.
} 
revisão bibliográfica. O intuito foi compreender como essas representações são importantes para entender o território do outro e perceber como esse outro é capaz de representá-lo.

Para isso, constatou-se que esse processo deve ocorrer com 0 desenvolvimento de representações que sejam realmente representativas para a comunidade, que seja uma expressão mais plural de pensar o território, e que a imaginação e a memória façam parte desse processo, revelando uma diversidade imagética muito mais complexa de entender em termos de representação de espacialidades. No caso dos povos Guarani, as diferentes formas de representação fazem parte de seu universo, bem antes do desenvolvimento da escrita, como forma de expressão de seu mundo.

Os trabalhos de campo, da forma que ocorreram, foram fundamentais para o desenvolvimento da pesquisa, pois a cada experiência na comunidade, novas ideias e dúvidas surgiram, como consequência do acúmulo de vivência que possibilita ao pesquisador se refazer a cada oportunidade. Segundo Alkmin (2014, p. 9):

Pode-se dizer que, quando alguém sai a campo e mergulha com profundidade nas paisagens e situações nas quais transita, acaba por experimentar uma situação deveras singular: observa a si próprio refletido nos olhos daqueles que observa, percebendo, ao final sua própria maneira de olhar [...].

Portanto, os primeiros trabalhos de campo foram estruturados conforme 0 interesse e a disponibilidade da comunidade em receber e participar de entrevistas e oficinas. Em decorrência dessa opção, por não apresentar um projeto fechado quanto ao desenvolvimento dessa pesquisa, os trabalhos de campo derivam do interesse dos participantes em determinados assuntos. Os temas principais foram apresentados e a partir deles foi sendo estruturada atividade por atividade, conforme os resultados das atividades anteriores e, também, a partir de novas pesquisas bibliográficas relacionadas aos temas. 
Uma das questões para o desenvolvimento da metodologia diz respeito às observações realizadas por Leite (1998), com relação a importância do uso das imagens e representações como objeto de pesquisa, pois elas estão em constante diálogo com o texto verbal. Segundo Leite (1998, p. 44):

O desenho ou a fotografia não reproduzem abstrações. Representam um caso concreto, um fato particular, o presente. [...] Mecanismos perceptivos e cognitivos ampliam a compreensão das relações entre a imagem e as diferentes formas de memória, que, pelo reconhecimento e pela rememoração, constroem a ponte para o texto verbal. Ao que é impossível descrever, torna-se indiscutível a prioridade da imagem visual, por sua capacidade de reproduzir e sugerir, por meios expressivos e artísticos, sentimentos, crenças e valores.

É necessário pontuar que não é finalidade desta pesquisa fazer uma discussão aprofundada ou equacionar divergências sobre os conceitos de representação, mapa mental, imagem e suas definições derivadas. No entanto, muitos autores apresentados trabalharam com definições diversas, o que não impede a leitura dos pontos em comum que permitem sua relação e utilização no desenvolvimento de uma metodologia. Portanto, limita-se aqui a utilizar o conceito de representação, devido sua operacionalidade para entender a constituição do conhecimento sobre o mundo por meio de diferentes manifestações visuais, orais e artísticas. Segundo DEBARBIEUX (2007):

A representação, concebida como uma entidade material ou ideal, que dá forma e conteúdo a uma entidade postulada do real, responde a essa necessidade. Sua pertinência se avalia na sua capacidade para constituir um modelo eficaz do real que ele representa.

A metodologia de análise das representações proposta por Harley (2015)direcionou o olhar para os aspectos que contribuem para entender a relação e a conexão entre as diferentes formas de representação do Território Guarani da Serra do Mar. As representações foram decodificadas na interlocução com o seu produtor, com uma investigação sobre o desenhista, seu contexto de produção, a 
relação com demais representações que foram produzidas, o significado da ausência e presença de elementos (HARLEY, 2015).

Em relação à questão da ausência e presença de lugares nas representações, é possível constatar diversas explicações. Por esse motivo o diálogo com o produtor da representação é necessário e fundamental, pois evita leituras descontextualizadas, o que pode induzir a erros de interpretação. Com relação a essa questão Staszak (2003, p. 133) ${ }^{20}$ aponta que há menos críticas em relação à relevância dos chamados "mapas mentais" do que em relação às interpretações que podem ser feitas deles, ou seja, a questão central colocada é mais em relação às leituras que são feitas dos elementos visuais dos mapas.

\begin{abstract}
Numerosas críticas vieram à luz do dia nos anos 1980-1990, menos a propósito do mapa mental em si, em relação ao qual muitos especialistas admitem ter interesse, mas a respeito de sua utilização exclusiva nas pesquisas e nas interpretações que eles, por vezes, autorizam. Assim, por exemplo, pode-se interrogar, simplesmente, sobre o que significa a presença ou ausência de um lugar sobre um mapa mental. Essa interrogação gera perplexidade, pois se pode constatar casos onde os lugares representados são desvalorizados pelo indivíduo e pouco - até jamais - praticados, enquanto que os espaços omitidos são, se escutarmos as pessoas quando as interrogarmos, suportes de um imaginário de muita vitalidade.
\end{abstract}

Essa situação converge totalmente com o ocorrido quando disponibilizado uma sequência de 6 lápis de cor e 6 giz de cera para os Guarani da aldeia Tekoá Tenondé Porá. Questionados dos porquês das cores utilizadas nas representações, eles não tiveram uma resposta óbvia, pois as cores tinham significados diversos, não apresentando uma lógica em sua utilização. Portanto, acredita-se que tecer considerações sobre a utilização das cores nas representações poderia induzir a uma leitura errônea, optando-se por abordar outros elementos mais significativos e menos polissêmicos.

Observando outras experiências, concorda-se com as considerações da antropóloga Luz Boelitz Vidal (2001), que investigou a percepção das cores na

\footnotetext{
${ }^{20}$ Tradução realizada por Jaime Tadeu Oliva
} 
sociedade indígena Kayapó-Xikrin do Bacajá, no sudoeste do Pará. A metodologia adotada por ela consistiu em disponibilizar 36 lápis de cores, colocados em uma sequência fixa, a três participantes da pesquisa. $O$ resultado destacou o fato de que as representações mentais das cores dos indígenas são polissêmicas e os significados só podem ser entendidos nos contextos específicos, pois são carregados de simbologias "cujos significados variam segundo os contextos em apreço" (p. 219). É importante observar que os indígenas têm significativo interesse pelas cores e que esse aspecto deve ser observado e analisado.

No que tange às metodologias envolvidas nas análises de representações, há grandes divergências teóricas, mas, também, marcos. Na década de 70, Gould e White (1974) desenvolveram, no livro Mental Maps, estudos sobre as imagens que as pessoas formam dos lugares. Essas imagens são filtradas por uma série de informações prévias que cada sujeito tem. Segundo essa visão, as informações prévias interferem e interagem com as percepções espaciais.

O estudo de Gould e White (1974) teve como ponto de partida o mapeamento da geografia das preferências relacionada à imagem mental que as pessoas constroem dos lugares. Há uma proposta para se entender que as imagens formadas sobre os espaços são relacionadas à memória desses sujeitos, aos aspectos culturais que as fazem ser substancialmente diferentes uma das outras, mas que ao mesmo tempo também podem revelar aspectos que lhes dão conexão.

As "paisagens invisíveis", conceito bastante operacional para esta pesquisa, trabalhado por Gould e White (1974), faz referência às imagens que são formadas a partir da percepção espacial, mas que podem não ser transferidas para o papel. Essas paisagens invisíveis podem ter relação com elementos do campo cultural que justificam a ausência ou presença de um espaço ou objeto sobre o mapa mental desenvolvido. Isso evidencia a importância de se observar esses fatores sobre as representações, não como uma simples escolha do que desenhará, mas como uma complexa explicação sobre as preferências dos lugares.

Nas representações Guarani, isso é exteriorizado pela preferência em representar somente o núcleo habitacional, área na qual tem um significado 
cultural muito forte devido à presença de elementos que permitem o exercício diário da espiritualidade, como a casa de reza. As representações vão diferir conforme o gênero, idade e a função que os sujeitos exercem na comunidade. Ponto que será destacado na apresentação dos resultados da pesquisa.

As considerações sobre mapas metais foram apresentadas devido ao fato de contribuírem no desenvolvimento da metodologia de análise das representações, inserindo-se dentro de uma perspectiva mais ampla sobre as práticas cartográfica que estão baseadas na perspectiva de trabalho de uma cartografia social e participativa. Os autores ligados a cartografia social tem como foco o desenvolvimento de mapeamentos participativos, para isso utiliza-se de diversos instrumentos de representação, como os mapas mentais, representações 3D, mapas georreferenciados, entrevistas, observação e participação, tendo em vista, sobretudo as questões relacionadas aos conflitos e impasses territoriais.

As representações também são importantes para a introdução da discussão sobre o que é mapa e elucidar as primeiras noções sobre cartografia. Fato que se comprovou devido aos significativos resultados obtidos por meio da realização de oficinas de cartografia, na qual a representação do território possibilitou introduzir e problematizar elementos do campo da cartografia e da dimensão territorial Guarani.

Gomide e Santos (2005), em experiência de registro Terras Indígenas por meio de mapas mentais, constatou que estes podem contribuir para realizar levantamentos de problemas socioambientais em comunidades. Essa constatação feita por eles converge totalmente com os resultados que serão apresentados mais adiante, pois no caso de uma representação realizada por uma Guarani em trabalho de campo, uma das questões centrais colocada foi a dos problemas ambientais, como a contaminação de rios que atinge diretamente a comunidade Tekoá Tenondé Porã. 


\title{
CAPÍTULO I:
}

\section{O UNIVERSO DA CARTOGRAFIA EM GEOGRAFIA}

\begin{abstract}
O objetivo deste capítulo é apresentar experiências cartográficas realizadas com diferentes grupos sociais e sua importância e influência no campo da pesquisa geográfica. Foi realizado um levantamento bibliográfico a partir do que se denomina de forma mais ampla como cartografia social e participativa. $O$ intuito foi buscar diferentes formas de trabalho com representações e entender como elas podem contribuir para a representação e apreensão de perspectivas diversas de território. Considerou-se que uma perspectiva mais alargada do território pode vir a possibilitar uma transformação do imaginário espacial, ou seja, desconstruir uma visão reducionista do território que está mais atrelada a limites e fronteiras.
\end{abstract}




\subsection{A CARTOGRAFIA E A RENOVAÇÃO DO MAPA}

"Cartografía nunca é apenas o desenho de mapas - ela é a

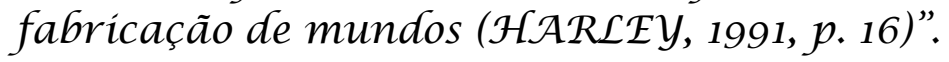

Parte significativa da produção bibliográfica em geografia tem uma resistência significativa a aceitação de uma cartografia mais plural, baseada na diversidade imagética de grupos. A definição de mapa, de muitos trabalhos, está largamente ligada às definições mais reducionistas, como se o mapa fosse somente aquele que tem coordenadas geográficas, fora disso, não é mapa e, portanto, não é científico (FONSECA, 2004). Essa visão reducionista limita as possibilidades de desenvolver uma cartografia mais ampla, chocando-se com a acepção de mapa adotada nessa pesquisa. Por esse motivo, constata-se a necessidade de uma maior diversidade de mapas nos estudos geográficos, principalmente quando o objetivo consiste em entender a visão do outro sobre o seu território.

Segundo Harley (1991, p. 59), o mapa é uma "representação gráfica que facilita a compreensão espacial de objetos, conceitos, condições, processos e fatos do mundo humano". Para Harley (1989), os mapas devem ser vistos como textos construídos a partir de signos. Eles são linguagens que descrevem o mundo, e têm o mesmo sentido que os sistemas de signos verbais. Essa definição de mapa de Harley (2005) se choca com as definições de mapa mais restritas, largamente presentes nas concepções dos trabalhos que tratam o mapa na cartografia, como se pontuou anteriormente.

Os mapas ligados à precisão cartográfica, considerados mais objetivos por sua "acurácia", devem ser entendidos como produto de um determinado juízo de valor e contexto cultural, são chamados de mapas hegemônicos, não como uma verdade absoluta e inquestionável. Isso se reflete nas pesquisas com 
comunidades quando a única forma de representação do território do outro é por meio do mapa euclidiano.

A projeção desse cenário pode ser percebida na recorrente redução do território indígena a uma cartografia praticada pelo outro, pertencente à cultura do outro, onde "convencionou-se chamar de mapa aquelas construções que obedecem a padrões (GIRARDI, 1997, p. 16)".

Muitos cartógrafos estiveram presos à ideia da existência de mapas "primitivos" (HARLEY, 2005). Essa concepção, que sempre gozou da aceitação geral da comunidade científica, com o advento da era da tecnologia, foi ainda mais intensificada. Segundo Harley (2005, p. 72) "Todos os mapas são culturais porque manifestam processos intelectuais definidos como artísticos ou científicos na medida em que trabalham para produzir um tipo específico de conhecimento".

Os mapas euclidianos são instrumentos políticos apropriados e orientados para atender os interesses das comunidades indígenas, objetos que o "Juruá" 21 exige para que eles tenham posse sobre suas Terras. No entanto, ao propor fazer uma leitura dos elementos da percepção indígena sobre o território, esses mapas são insuficientes, tendo em vista que historicamente essa foi uma das armas utilizadas contra eles. A pesquisadora Irène Hirt (2013, p. 65), que trabalhou com mapas nas comunidades Mapuches, sublinha que:

Como apontou a cartógrafa hawaiana Renne Pualani Louis (2004), os povos indígenas têm sido silenciados pelos limites das ferramentas proporcionadas pela cartografia ocidental. Orientados para a objetividade empírica, estas ferramentas marginalizam as expressões indígenas.

Os mapas com precisão topográfica são aqueles feitos dentro de uma concepção de espaço, no caso o espaço euclidiano. Segundo Lèvy (2003, p. 351):

\footnotetext{
${ }^{21}$ Juruá quer dizer, literalmente, "boca com cabelo" uma referência à barba e ao bigode dos europeus portugueses e espanhóis conquistadores. De todo modo, o nome Juruá foi criado a partir do contato com os brancos colonizadores e passou, com o tempo, a ser uma referência utilizada genericamente a todos os não - índios (LADEIRA, 2008, p. 73 apud LADEIRA, 1990).
} 
Numa definição restrita, o espaço euclidiano é aquele construído segundo uma métrica euclidiana, tendo como referência a geometria concebida pelo grego da Sicília Euclides (450-380 a.C). Esse espaço supõe a continuidade (nada de lacuna) e a contiguidade (nada de ruptura), mas também a uniformidade (métrica constante em todo ponto). É um caso particular do que em matemática denomina-se como "espaço métrico"22.

De modo geral, a Geografia tem concebido os mapas, majoritariamente os euclidianos, como produtos que conferem às suas pesquisas sua posição na ciência geográfica (GIRARDI, 1997). No entanto, a proposta aqui foi observar e analisar os recortes territoriais a partir das representações diversas.

Em relação à questão indígena, para que seus territórios e territorialidades fossem reconhecidos, cada vez mais eles foram tratados em mapas com precisão euclidiana, os "considerados" mapas "científicos". No primeiro momento, essa foi uma forma de reconhecimento dos direitos territoriais indígenas. Porém, os povos indígenas se apropriam desses mapas e de suas técnicas de produção como um conhecimento fundamental e necessário para o diálogo e representação de suas espacialidades.

O conceito de representação é fundamental para expressar o ponto de vista adotado, porque as análises não se limitam somente ao mapa ou a fala, mas as diferentes formas que podem ser percebidas de representação do território por comunidades. Essa perspectiva da representação converge com uma definição muito mais ampla e diversa de mapa, como a apresentada por Harley (2005).

No cenário internacional, o conceito de representação vem sendo adotado pela sua operacionalidade nas pesquisas científicas. Segundo Debarbieux (2007, p.1):

Na geografia francófona contemporânea, pronta a adotar um modo de pensamento dialético e preocupado por guardar entre seus lineamentos as propostas sobre transformação do real geográfico, numerosos trabalhos contemporâneos se referem ao conceito de representação para destacar a eficácia prática e o caráter operativo; a representação dispõe de um lugar tanto mais central nas problemáticas disciplinares quanto que são concebidas como

\footnotetext{
22 Tradução de trabalho de Jaime Tadeu Oliva e Fernanda Padovesi Fonseca.
} 
condição, motores e prefigurações da ação em geral, do ordenamento em particular.

É importante pontuar que o objetivo não consiste em discutir, problematizar e equacionar as diferentes definições dadas às representações, pois certamente demandaria significativo esforço o qual é totalmente dispensável devido aos objetivos propostos. Ele será concebido como um conceito que é operacional para entender a constituição do conhecimento sobre 0 mundo por diferentes sociedades por meio de suas representações (DEBARBIEUX, 2007), o que converge com uma visão mais alargada do mapa, ou seja, como uma representação da realidade, como visão de mundo de um grupo social específico que está inserido em textos e contextos totalmente diversos (HARLEY, 2005).

Cada representação, bem como cada mapa está atrelado a diferentes dimensões: material e social, situadas em contextos específicos. O mapa, como um tipo de representação, é uma invenção de determinadas culturas. Cada sociedade tem sua própria forma de perceber e representar seu espaço, sendo uma linguagem universal e uma das mais antigas.

Essa visão se aplicaria aos mapas produzidos pelos indígenas, pois seu mapa reproduz uma dada ordem social, além de ser uma forma de interpretação do mundo, e como o interesse consiste em entender o território do outro a partir de suas representações, essas representações Guarani oferecem uma gama de possibilidade de interpretação.

Nesse contexto, os mapas são considerados "um discurso - um sistema que dispõe de um conjunto de regras para a representação do conhecimento intrínseco às imagens que definimos como mapas e atlas" (HARLEY, 1989, p.12). Harley (1989) coloca que o mapa não é algo objetivo e inquestionável. Segundo ele, nenhum mapa representa uma visão exata da realidade. Portanto, as representações Guarani não buscam exatidão, mas aproximação de uma realidade.

A denominada cartografia social oferece experiências interessantes e significativas, pois é discutido não só o ato de cartografar, mas a dimensão territorial e os conflitos inerentes à lógica de dominação material e simbólica do 
território pelos sujeitos. Seria aquilo que HOFFMANN (2010, p. 70) denominou de "reencantamento cartográfico"23.

No auge do 'objetivismo' cartográfico, com a popularização dos instrumentos de informação geográfica, parece ocorrer 0 reencantamento da cartografia, ou pelo menos de parte dela, com a produção de mapas que recuperam o conhecimento tradicional espacial, o simbólico, as identidades existentes ou recriadas e suas territorialidades, em um contexto em que este simbólico articula-se com a objetividade de uma legislação de acesso à Terra. Assim, esta nova cartografia politiza uma ciência que por muitos era pensada apenas como uma técnica associada a uma tecnologia.

A cartografia social, atrelada à discussão de dinâmica territorial, desenvolve um trabalho com representações coletivas e individuais a partir da confecção e análise de mapas e representações feitas por comunidades quilombolas e indígenas, de forma participativa. O resultado é interessante, pois aponta os pontos positivos e negativos do trabalho com essas novas possibilidades de construção coletiva de representações dos territórios por atores diversos, dentro de um campo de disputa de interesses. Segundo Acserald (2010, p.10):

A ampliação dos espaços e a diversificação das formas de representação espacial, além da emergência de novas tecnologias e de novos "sujeitos mapeadores" deram lugar à constituição de um campo da representação cartográfica onde se estabelecem relações entre linguagens representacionais e práticas territoriais, entre a legitimidade dos sujeitos da representação cartográfica e seus efeitos de poder sobre o território.

A cartografia é vista como um meio pensamento espacial de análise e comunicação, portanto, ela é o núcleo dessa pesquisa, já que permite alcançar os objetivos pretendidos, entendendo os arranjos e desarranjos do território do ponto de vista Guarani. Em termos de linguagem, o mapa protagoniza uma narrativa

\footnotetext{
${ }^{23} \mathrm{Com}$ as novas tecnologias há um leque de possibilidades que permite o desenvolvimento de novos produtos cartográficos mais democráticas, se antes a cartografia estava enclausurada em poucos escritórios, hoje há uma expansão e disseminação de ferramentas de mapeamento coletivo que possibilitam cada vez mais a participação e politização de minorias.
} 
sobre o território. Ela não é única, mas múltipla, e depende das apostas cartográficas feitas pelos sujeitos. O mapa deve ocupar o lugar central dentro de uma perspectiva cartográfica de estudo das espacialidades. Segundo Fonseca e Girardi (2016, p. 68): "No caso, os textos e outros discursos verbais sequênciais perdem a primazia para o mapa, como polo consistente de um discurso construído coletivamente".

\subsection{A CARTOGRAFIA COMO POSSIBILIDADE DE LUTA E RESITÊNCIA}

Com tantas denominações, melhor mesmo é assumir que o conjunto de práticas levadas a cabo com o intuito de incorporar as comunidades tradicionais nos processos de construção de mapas devem ser denominadas como participativas ou sociais. Embora se tenha essa diversidade de experiências com diferentes denominações, todas buscam o mesmo objetivo: serem democráticas e participativas. Segundo Fonseca e Girardi (2016, p. 68) é possível definir que:

A cartografia participativa constitui, junto aos diversos processos participativos, a possibilidade de que parte da sociedade, normalmente excluída dos processos decisórios de toda ordem, tenham voz ativa na definição das políticas que afetam seus espaços, por conseguinte suas vidas.

Segundo Burini (2012, p. 1), pesquisadora da Universidade de Bergamo, na Itália, que desenvolve trabalhos com cartografia participativa em comunidades tradicionais da África subsaariana, os resultados desse campo do conhecimento permitem entender as espacialidades das comunidades, além de conduzir a ações de planejamento muito mais eficazes. Esse foi o caso da experiência realizada por Burini (2012, p. 10, tradução nossa). 
A cartografia participativa tem potencialidade no que se refere à planificação territorial, para reconstruir as mudanças espaciais, para criar um confronto entre os diferentes atores sociais, para representar informações espaciais até então inéditas, porém necessárias para evitar que as ações de planejamento sejam realizadas sem conhecimento da realidade local e dos desejos dos atores que lá vivem.

A cartografia participativa deve ser entendida como um instrumento de pluralidade de atores, essencial para a tomada de decisões nos processos de planejamento. Essa postura permite que ocorra uma gestão dos recursos naturais que é viabilizado pelos conhecimentos tradicionais sobre o território. Segundo Vianna (2008, p. 5): "a valorização do conhecimento tradicional espacial no Brasil, tem sido determinante para a formulação de novos instrumentos de políticas públicas e de ordenamento territorial, regularização fundiária e acesso à Terra".

Um exemplo de como os estudos voltados para o fortalecimento desse instrumento de leitura da sociedade, o mapa, incorpora novas roupagens e assume novos papéis é o caso dos projetos desenvolvidos na região da Amazônia denominado Nova cartografia social da Amazônia (PNCSA), que contribuem significativamente para o reconhecimento dos territórios indígenas e de comunidades tradicionais, pautado na construção coletiva de planos de manejo de áreas.

A cartografia se mostra como uma possibilidade de luta e combate às forças diversas que concorrem na apropriação dos territórios das comunidades. As experiências do projeto Nova Cartografia Social da Amazônia configura-se como uma possibilidade metodológica de trabalho com mapeamento que teve resultado e foi incorporado no manejo de áreas e reconhecimento de territórios, bem como seu monitoramento contra as constantes ameaças provenientes de atividades ilegais em tais áreas ${ }^{24}$. É importante pontuar que o trabalho realizado na aldeia Tenondé Porã não influenciará diretamente na planificação dos territórios, como é o caso das experiências que foram relatadas anteriormente, mas como essa pesquisa se propõe a discutir metodologias para esse tipo de

${ }^{24}$ Consultar site da: www.novacartografiasocial.com. 
trabalho é fundamental essa introdução de experiências que estão ocorrendo em âmbito nacional e internacional.

Do mesmo modo, os mapeamentos participativos são aquelas experiências práticas que têm como objetivo desenvolver formas mais democráticas de construção de mapas. Joliveau (2008, p. 38) coloca que: "[...] participativo entende ligar os atores e o território, construir o território com os atores e mobilizar estes atores através do território sob a hipótese de que nessa relação um e outro se transformam".

As primeiras produções de mapas em comunidades de agricultores, quilombolas e povos originários foram chamadas de "agrimensura camponesa". Nessa experiência, as populações eram convocadas a identificar e opinar sobre 0 espaço onde viviam. As comunidades, de forma empírica e fundamentada na experiência cotidiana do território, elaboravam mapas e desenhos representando o meio físico e social onde estavam inseridos (MILAGRES et al., 2010).

Os mapeamentos foram impulsionados pela necessidade de cada potência imperial ter um inventário cartográfico zenital apropriado para as incursões de exploração do novo mundo (Martinelli, 2006). Desse modo, os mapeamentos podem ser estudados como um mecanismo de introdução de dominação sobre diferentes povos.

Para KoK (2009, p. 92), a expansão da colonização na América portuguesa ocorreu sobre o apoio de uma chamada "cartografia indígena", ou seja, boa parte do conhecimento cartográfico necessário para o processo de colonização esteve pautado sobretudo no conhecimento indígena sobre o território. Os conhecimentos indígenas foram imprescindíveis na elaboração dos primeiros mapeamentos dos recursos naturais e dos caminhos e trilhas necessárias à circulação e mobilidade naqueles territórios que eram até então desconhecidos para o colonizador.

Técnicas e estratégias complexas, transmitidas pelos nativos aos paulistas, viabilizaram as sistemáticas expedições pelo sertão bandeiras, monções e levas de povoadores para as fronteiras -, capazes de enfrentar florestas tropicais, descampados, serras íngremes, rios encachoeirados e terrenos pantanosos. Nessas empresas coloniais, as contribuições dos grupos nativos foram 
imprescindíveis no que se refere a fornecer informações detalhadas não só sobre a topografia e a geografia, bem como outros conhecimentos, necessários à elaboração de mapas, esboços, técnicas de representação e orientação nos caminhos terrestres e fluviais do sertão. Esses conhecimentos integravam a "cartografia indígena", isto é, um acervo de informações espaciais, construído pela memória e enraizado, principalmente, nos sentidos.

Essa cartografia indígena, baseada nos sentidos, traduz- se pela habilidade dos indígenas, que pode ser comparada a dos animais, visto que os sentidos dos indígenas são fortes, pois circulavam e circulam por meio dos sons e das árvores (como o Jerivá) ${ }^{25}$, bem como sobre a orientação dos astros e das diferentes paisagens, resultado de uma relação intima com a natureza que é mantida por meio dos laços culturais, algo que faz parte de uma cartografia indígena dos sentidos.

Além dos indígenas terem notável habilidade para desenvolver representações sobre seus territórios, a mobilidade era marcada por meio dos caminhos abertos que permitiam a circulação, é o caso do caminho conhecido como Peabiru, que ligava as comunidades Guarani da bacia do Paraguay, bem como da região do rio Paranapanema (KOK, 2009).

Os mapeamentos participativos se tornaram mais evidentes na América Latina a partir da década de 1990. No Brasil, a demarcação e titulação de diversas Terras indígenas e quilombolas foi realizada por meio de metodologias de mapeamento participativo, considerada como "elemento central na produção e na delimitação das fronteiras étnicas de povos indígenas e comunidades tradicionais" (HOFFMANN, 2010, p. 64).

Segundo Bavaresco (2009), as metodologias participativas contribuem para uma maior interação entre os conhecimentos indígenas e o conhecimento científico, permitindo a criação e recriação de metodologias de trabalho que contribuem para o desenvolvimento de propostas de mapeamentos mais democráticas.

\footnotetext{
${ }^{25}$ Continuar aquiexplicar sobre o jerivá
} 
Há críticas aos chamados "mapeamentos participativos" atualmente, pois o que deveria ser para as comunidades um instrumento de poder para mudar a realidade acaba, por vezes, sendo somente um instrumento dos interesses alheios. É nessa situação que esse tipo de produção cartográfica não proporciona os instrumentos necessários para entender o território do outro, mas de mecanismos contra as próprias comunidades, que são expulsas de seus territórios.

Almeida (1995) aponta a dificuldade em trabalhar com os mapas desenvolvidos por órgãos governamentais, identifica que, para muitas comunidades, esses mapas são ineficientes, pois a linguagem utilizada não é entendida e as informações que o mapa quer passar não são compreendidas.

O desenvolvimento de mapeamentos participativos não deveria levar em consideração, em um primeiro momento, o espaço euclidiano. É necessário, antes de se chegar a esses mapas, discutir com a comunidade a representatividade desses instrumentos, colocá-los em seu devido lugar não como verdade absoluta, mas como uma possibilidade, como uma perspectiva, dentre as diversas que existem. Essa posição é um resultado constatado em campo.

A cartografia produzida pelas comunidades, ao contrário da almejada neutralidade, possui fortes objetivos persuasivos, pois seleciona elementos que são marcantes na cosmologia das comunidades, transmitindo um tipo de informação cartográfica específica, é o que será observado nos mapas produzidos pela comunidade Tekoá Tenondé Porá.

Desse modo, essas questões podem ser associadas ao que aponta Harley (2005) de que a cartografia é um instrumento de poder ligado, sobretudo ao trabalho do cartógrafo, portanto quando se pensa o universo da cartografia devese estar disposto a compreender as mais diversas manifestações representacionais das espacialidades. Nas suas palavras: "Se na verdade nos preocupamos com as consequências sociais do que passa quando fazemos um mapa, também podemos decidir que a cartografia é muito importante para ficar totalmente nas mãos dos cartógrafos" (HARLEY, 2005, p. 245). 
Irène Hirt (2013) aponta que a cartografia realizada nas comunidades Mapuches reflete mais o território perdido do que o atual, pois o processo de colonização é responsável pela dizimação dessas comunidades. Caso parcialmente semelhante é o das comunidades da Serra do Mar, em São Paulo, que têm representações ligadas ao território perdido que abrange uma área ainda não homologada, com ocupação efetiva dos mesmos por meio das aldeias permanentes e transitórias.

\section{3 O TERRITÓRIO DO MAPA E O MAPA DO TERRITÓRIO}

O território surge com o mapa e o mapa aparece com o território. Há uma relação extremamente íntima entre essas duas variáveis e dificilmente se pode separar uma da outra. As representações do território Guarani, produzidas a partir dos mapas e falas, possibilitam entender o território que é expressado por meio de representações diversas da realidade.

É interessante notar que o surgimento da noção de território só chega, para muitas sociedades, com o mapa do colonizador. É a partir do ato de delimitar e controlar o espaço por meio dos mapas da época colonial que o conceito de território, terrestre ou marítimo, é introduzido no imaginário de muitos povos. Seguindo essa perspectiva, Anderson (2008, p. 236) coloca que no sudeste asiático: "O mapa de Mercator, introduzido pelos colonizadores europeus, começava, impresso, a modelar a imaginação dos sudeste-asiático [...]".

A ideia de território, assim como se percebe hoje, chegou para as comunidades indígenas no Brasil com o mapa do colonizador, do mesmo modo que observou Anderson (2008) no caso das comunidades do sudeste asiático:

Foi apenas nos anos 1870 que as lideranças tailandesas começaram a pensar nas fronteiras como segmentos de uma linha contínua num mapa, que não correspondia a nada visível no chão, 
mas que demarcava uma soberania exclusiva contida entre outras soberanias.

Patrick Poncet (2013, p.1) coloca que o mapa em si é o território, pois se inscreve nas relações sociais que as sociedades estabelecem sobre o espaço geográfico:

Muitas vezes, e bem mais frequentemente do que se imagina, a existência do mapa do território basta para provar a existência do território. Melhor que isso, todo mapa produz o território mais que ele o representa; o mapa é o território, por si só. Jamais ninguém viu nem verá o Mundo, no entanto, ele existe. E o nosso intelecto não o acessou senão por meio de representações, ao primeiro lugar destas se encontra o mapa.

As formas de mapear de um cartógrafo e de um nativo são diferentes, pois o que o nativo mapeia traz, no ato de mapear, a expressão de um mundo possível, revelando facetas do território não observadas pelo cartógrafo. O cartógrafo, em sua postura mais tradicional, desconhece o território mapeado ou o enxerga como uma grade de coordenadas geográficas, estas, por sua vez, definirão o futuro das áreas dessas "comunidades" (CARDOSO, 2013).

O mapa do colonizador continua impondo seu conceito de território, seu mapa não dialoga, nem dialogará, com o mapa do "colonizado". No entanto, esse "colonizado" deve se apropriar da linguagem do outro em beneficio próprio. Portanto, o inédito é estar no mapa do outro, ter visibilidade e comando do que, até então, supostamente, estaria sobre domínio do outro.

O mapa é uma construção social e, dependendo das variáveis e atores que são considerados na sua confecção, ele pesa para uma parcialidade. A definição de delimitações, áreas e usos é construída de acordo com as relações de poder. Como aponta Harley (2005, p. 246):

[...] na medida em que o mapa é construído e projetado a partir de uma determinada posição na estrutura social e de um lugar institucional próprio, ele se inclina para a parcialidade de quem os produziu. A aparente neutralidade na reprodução de acidentes físicos e de elementos da natureza fica comprometida, quando se 
detectam disputas em torno do acesso e do controle da Terra, dos recursos naturais $[\ldots]$.

É preciso compreender a importância de um mapa dentro de um contexto particular, de um tempo específico. É preciso um estudo aprofundado, não apenas dos mapas, mas dos processos de mapeamento que empregam novos olhares sobre a porção do território representado. Esses diferentes olhares são expressos na diversidade imagética constatada nas representações Guarani de mundo.

Mapas, como os desenhados pelos Guarani, são uma possibilidade de representação gráfica do território, pois é compreendido como um enunciado visual e produtor de uma dada ordem discursiva que permite realizar leituras das representações de seus territórios, desvendando a diversidade imagética (LÉVY, 2008) desses grupos, como abordou-se anteriormente. Pois, segundo Lévy (2008), os múltiplos pontos de vista são legítimos quando se pretende entender percepções, comportamentos e representações dos objetos de estudo. Da mesma forma, o "mapa" se apresenta como uma expressão da assimilação simbólica do território concreto, inserido na lógica de disputa pela dominação do mesmo.

Dentro da geografia têm-se diversas definições do que é concebido como território, dentre elas, apresenta-se aqui a concepção na qual o território é dotado de múltiplos significados, materiais e imateriais, o território como fruto das relações de poder entre indivíduos, grupos de indivíduos e instituições, como coloca Raffestin (1993). Essas relações de poder, por meio de diferentes atores, constroem o território de acordo com o interesse de cada grupo, podendo ser político, econômico e cultural.

A definição utilizada pelos órgãos públicos para delimitar e demarcar áreas destinadas às populações tradicionais é Terra. No entanto, se pensarmos que ela só considera a demarcação do núcleo habitacional, como é o caso da comunidade Tenondé Porá, essa definição se torna insuficiente e problemática do ponto de vista territorial.

Em contrapartida, para os povos indígenas, a definição de um território é muito mais complexa. Para cada grupo, uma definição. Para os povos Guarani, o 
território é muito amplo e bem divergente da concepção de território delimitado por fronteiras, que entra aqui como uma ação sobre o espaço que os Guarani não concebem da mesma forma que a sociedade contemporânea.

Para os povos indígenas, a concepção de território deve ser singularizada, como observou Gallois (2004). Isso se deve as condições pós-coloniais as quais esses grupos foram submetidos, os limites e fronteiras tornam-se uma realidade, muitas vezes, necessária.

Como apontado anteriormente, o que se denomina de fragmento do território Guarani da Serra do Mar é constituído por 4 Terras Indígenas, sendo elas: Itaóca, Aguapeú, Rio Branco e Tenondé Porã. Devido à ampliação dos limites da Terra Tenondé Porã, as comunidades passarão a compartilhar suas fronteiras, configurando-se como uma estratégia, por meio dos instrumentos legais assegurados pela Constituição de 1988, para a apropriação efetiva da área da Serra do Mar, do Estado de São Paulo. Por meio da circulação, das trocas e do intercâmbio cultural, essas comunidades já estabelecem entre si contatos efetivos. No entanto, a circulação por esse território está comprometida, pois ainda não ocorreu a homologação para consolidação administrativa da ampliação da Terra da Tenondé Porá.

A estrutura e organização interna das espacialidades Guarani segue a seguinte lógica: aldeias permanentes: que são as de ocupação permanentes pelos Guarani, espalhadas pela região da Serra do Mar, garantindo a circulação entre os Guarani. Há também as aldeias transitórias, que são ocupações esporádicas distribuídas em lugares estratégicos pela Serra do Mar, como foi possível observar no mapa de aldeias apresentado inicialmente. As aldeias transitórias são como pontos de partida, de parada e de descanso entre os Guarani, pois o acesso e a circulação ocorrem entre as aldeias das Terras indígenas Rio Branco, Itaóca e Aguapeú, devido a sua cosmologia, a busca pela Terra sem mal.

Quando se fala em tekoá é o mesmo que dizer aldeia ${ }^{26}$. Uma Terra indígena pode ter diversas aldeias, enquanto que uma aldeia somente tem um

\footnotetext{
${ }^{26}$ As traduções são realizadas por Guarani, mas geralmente são limitadas devido ao processo de tradução.
} 
núcleo habitacional. Portanto, quando se fala em um fragmento do território Guarani, pressupõe uma área contínua de Terras indígenas, e não sua fragmentação, como "ilhas" isoladas. 


\subsection{A CONSTITUIÇÃO DA TERRA INDÍGENA TEKOÁ TENONDÉ PORÃ}

O processo de demarcação é o meio burocrático para delimitar os limites do território tradicionalmente ocupado pelos povos indígenas. Segundo o Ministério Público a união deve buscar com a demarcação:

a) resgatar uma dívida histórica com os primeiros habitantes destas Terras;

b) propiciar as condições fundamentais para a sobrevivência física e cultural desses povos; e

c) preservar a diversidade cultural brasileira. Tudo isso em cumprimento ao que é determinado pelo caput do artigo 231 da Constituição Federal ${ }^{27}$.

O Decreto ํo 1.775/96 dispõe sobre os procedimentos administrativos relacionados à elaboração, fases e subfases, do relatório circunstanciado de Identificação e delimitação de Terras Indígenas, bem como o papel do órgão federal indigenista. A primeira fase é composta por técnicos da FUNAl e comunidade indígena, após estudo é publicado o resumo do relatório, que foi utilizado nesta pesquisa, no Diário Oficial. As informações disponibilizadas pelo Ministério Público Federal sobre os procedimentos obrigatórios de realização do relatório passam por muitas fases, sendo elas:

O grupo de técnicos faz os estudos e levantamentos em campo, centros de documentação, órgãos fundiários municipais, estaduais e federais, e em cartórios de registros de imóveis, para a elaboração do relatório circunstanciado de identificação e delimitação da área estudada, resultado que servirá de base a todos os passos subsequentes ${ }^{28}$. É com base nestes estudos, que são aprovados pelo Presidente da FUNAI, que a área será declarada de ocupação tradicional do grupo indígena a que se refere, por ato do Ministro da Justiça - Portaria Declaratória

${ }^{27}$ http://www.mpf.mp.br; acesso dia 24/08/2017.

28 http://www.mpf.mp.br; acesso dia 24/08/2017. 
publicada no Diário Oficial da União - reconhecendo-se, assim, formal e objetivamente, o direito originário indígena sobre uma determinada extensão do território brasileiro.

A Fundação Nacional do Índio (FUNAI) é o órgão indigenista oficial do Estado Brasileiro. Constituída por meio da lei 5.371, de 5 de Dezembro de 1967, e vinculada ao Ministério da Justiça, é a principal instituição da política indigenista brasileira. Sua função é proteger e garantir os direitos dos povos indígenas do Brasil. É o órgão responsável pela regularização fundiária e registro das Terras indígenas. O monitoramento e a fiscalização das Terras ficam a cargo da instituição (FUNAI, 2014) ${ }^{29}$.

FIGURA 12: FASES PARA DEMARCAÇÃO DE TERRA INDÍGENA

\begin{tabular}{|c|c|}
\hline FASE & MOMENTO \\
\hline 1. Estudos de Identificação & Elaboração de relatório \\
\hline 2. Aprovação do relatório pela FUNAI & Publicação em 15 dias \\
\hline 3. Contraditório & Até 90 dias após a publicação do relatório pela FUNAI \\
\hline $\begin{array}{l}\text { 4. Encaminhamento do processo } \\
\text { adminstrativo de demarcação pela FUNAI ao } \\
\text { Ministério da Justiça }\end{array}$ & $\begin{array}{l}\text { Até } 60 \text { dias após o encerramento do prazo previsto } \\
\text { no item anterior. }\end{array}$ \\
\hline 5. Decisão do Ministério da Justiça & $\begin{array}{l}\text { Até } 30 \text { dias após o recebimento do procedimento. } \\
\text { Possibilidade de edição de portaria declaratória dos } \\
\text { limites da terra indígena, determinando a sua } \\
\text { demarcação. }\end{array}$ \\
\hline $\begin{array}{l}\text { 6. Homologação mediante decreto da } \\
\text { Presidência da República }\end{array}$ & \\
\hline 7. Registro & Até 30 dias após a homologação \\
\hline
\end{tabular}

FONTE: www.mpf.mp.br (2016).

A política de demarcação de Terras indígenas no Brasil sofreu grande variação, os gráficos com os dados coletados dos últimos 30 anos apresentam

${ }^{29}$ Informações retiradas do site da FUNAI. 
grande queda, isso se deve, em grande medida, as alianças que são feitas entre governantes e os setores ligados ao agronegócio, por exemplo. Essa questão obviamente não será discutida mais profundamente, no entanto, é imprescindível compreender o cenário atual quanto às possibilidades efetivas de concluir a demarcação da Terra indígena Tekoá Tenondé Porá.

É possível observar a significativa queda nas demarcações com a entrada da Presidenta Dilma Roussef de 2011 a 2016. As duas últimas demarcações ocorreram nos dois últimos meses da Presidenta no poder, se não somasse essas duas últimas, o número de demarcações cairia mais ainda. Em relação à área demarcada nos últimos 10 anos caiu muito. Constatações que são possíveis observar por meio das figuras 12,13 e 14 .

FIGURA 12: DEMARCAÇÕES DE TERRAS INDÍGENAS NO BRASIL

\section{DEMARCAÇÃO DE TERRAS}

Portarias Declaratórias

Número de terras Área (milhões de ha)

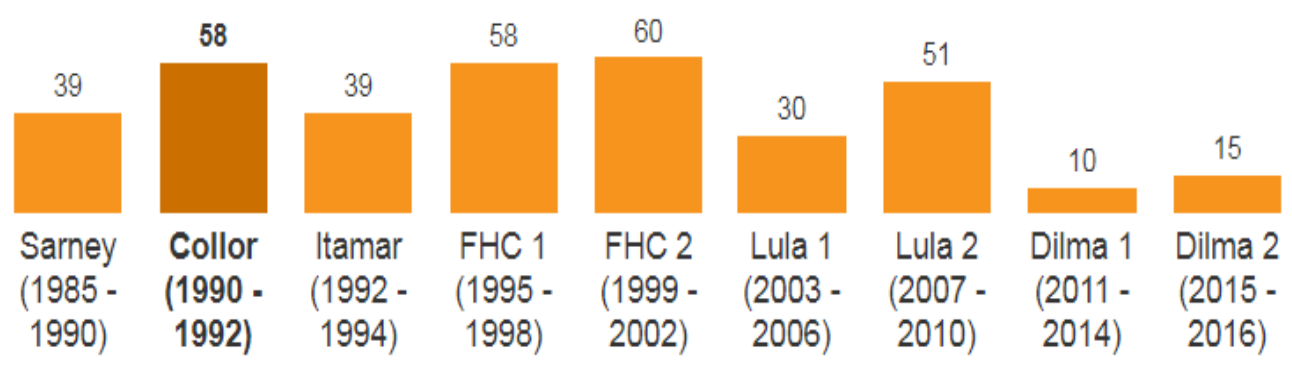

Obs.: Algumas terras indigenas homologadas em um determinado governo foram redefinidas e novamente homologadas em outro

FONTE: ISA: Instituto Socioambiental/ Folha de São Paulo (2016). 
FIGURA 13: DEMARCAÇÕES DE TERRAS INDÍGENAS NO BRASIL

\section{DEMARCAÇÃO DE TERRAS}

Portarias Declaratórias

Número de terras Área (milhões de ha)

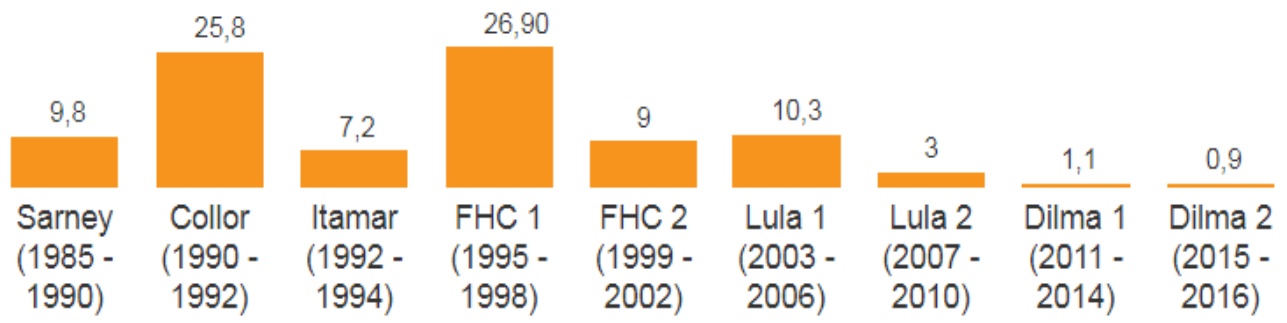

Obs.: Algumas terras indigenas homologadas em um determinado governo foram redefinidas e novamente homologadas em outro

Fonte: ISA (Instituto Socioambiental)

Confira mais infográficos da Folha

FONTE: ISA: Instituto Socioambiental/ Folha de São Paulo (2016).

FIGURA 14: DEMARCAÇÕES DE TERRAS INDÍGENAS NO BRASIL

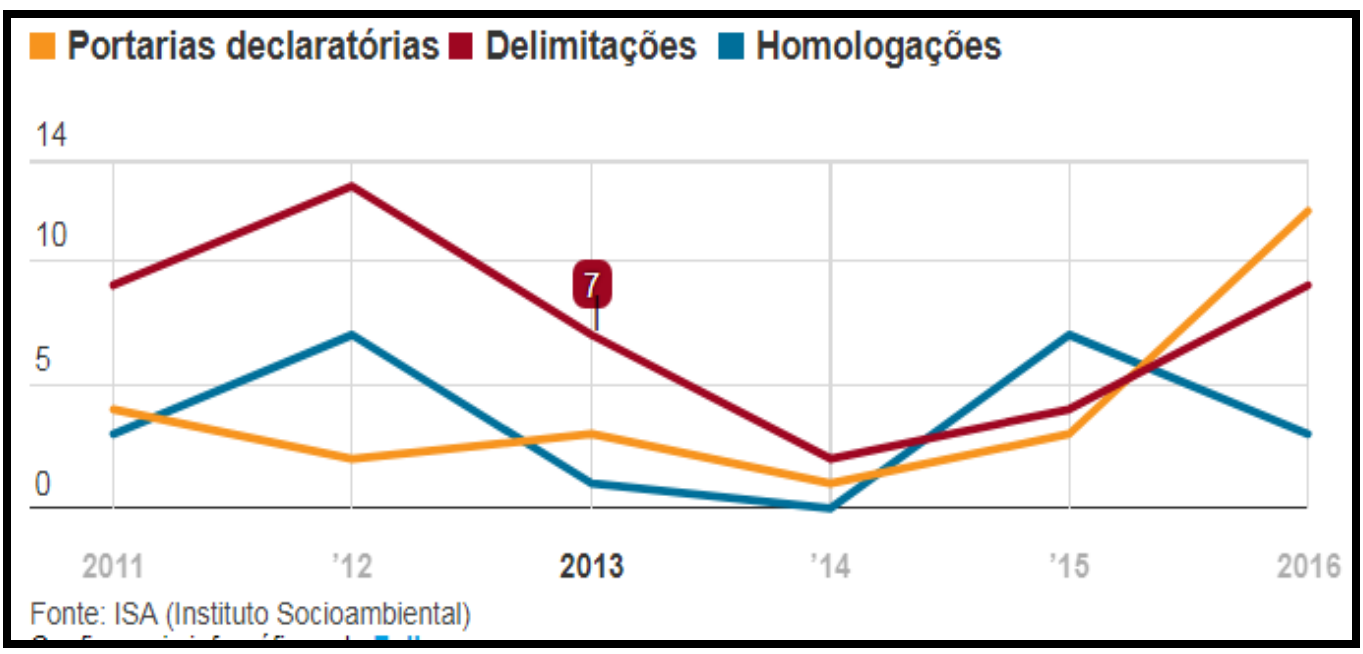

FONTE: ISA: Instituto Socioambiental/ Folha de São Paulo (2016). 
O resumo do relatório de identificação da Terra indígena Tenondé Porã (2012), ou seja, a definição do que seria necessário para o desenvolvimento do modo de ser tradicional Guarani, ocorreu por meio da memória oral, dos registros de cartório, pesquisas nos centros de documentação e também na observação participante, além de exploração da literatura disponível sobre a temática, utilizando também diferentes formas de representação do que seria essa Terra indígena.

No caso da TI Tenondé Porá, falta somente a homologação mediante decreto da Presidência da República. No dia 5/5/2016 o Ministro da justiça Eugênio Aragão assinou a Portaria Declaratória da TI Tenondé Porá. A portaria declaratória havia sido publicada em 2012, desde então os Guarani têm pressionado de inúmeras formas para a assinatura do documento. Segundo a Comissão Guarani yvyrupa (2016) ${ }^{30}$ :

Foram anos de atividades, manifestações, ocupações e muita reza pra Nhanderu kuery até que conquistássemos esse reconhecimento. Essa demarcação é fruto de muita luta, da força das xondarias e xondaros que apenas esta semana ocuparam a prefeitura de São Bernardo e o escritório da Presidência da República em São Paulo.

Os direitos indígenas, as políticas de seguridade social e educação escolar indígena são os objetivos que norteiam a atuação da FUNAI, que tem como base a democracia e o Estado pluriétnico.

A atuação da FUNAl está orientada por diversos princípios, dentre os quais se destaca o reconhecimento da organização social, costumes, línguas, crenças e tradições dos povos indígenas, buscando o alcance da plena autonomia e autodeterminação dos povos indígenas no Brasil, contribuindo para a consolidação do Estado democrático e pluriétnico (FUNAI, 2016) ${ }^{31}$.

\footnotetext{
30 Informações retiradas do Instituo Socioambiental: www.socioambiental.com.br: acesso dia 24/08/2017.

${ }^{31}$ Retirado do site da FUNAI:www.funai.gov.br: acesso em 24/08/2017.
} 
O peso social que ocupa essa instituição no cenário brasileiro é decisivo. Apontada como um órgão predominantemente indigenista, os conflitos em relação à atuação da FUNAl vêm suscitando diversos embates no cenário político atual, sobretudo após a criação da PEC $215^{32}$ que prevê o enfraquecimento da instituição no processo de decisão das demarcações.

A análise da relação entre estudos pretéritos, realizados por diversos antropólogos, e a observação da situação atual das comunidades que estão envolvidas na ampliação da Terra, foi importante para traçar o perfil do território em questão, categorizado como de uso das comunidades tradicionais.

A leitura realizada pelos antropólogos para chegar à conclusão da necessidade de ampliação da Terra e da importância do território, como mencionado anteriormente, é complementar aos estudos das representações, são duas metodologias distintas, mas complementares, tanto a antropológica, quanto a geográfica. No entanto, a FUNAI não trabalhou com o conceito de território, mas de Terra, que está previsto constitucionalmente.

Os estudos de cunho antropológico são imprescindíveis para mensurar a inserção daquele território nas imagens mentais daqueles povos, dando-Ihes significações diferentes. O que está em jogo é a flexibilização e a adoção de diferentes linguagens com o objetivo de alcançar essas mesmas constatações e, para isso, os estudos de outras representações do território são fundamentais.

Essas diferentes formas de leitura da sociedade não são antagônicas e nem excludentes, elas são complementares e convergem no sentido de buscar responder às questões que estão além do que é percebido em um primeiro olhar sobre as comunidades.

Os estudos da FUNAI indicam que a área homologada atualmente diz respeito somente aos núcleos de habitação, o processo de reconhecimento das Terras indígenas realizado na década de 1980 limitou-se a reconhecer somente os aldeamentos do território Guarani. O reconhecimento dessa pequena parcela

\footnotetext{
${ }^{32}$ A Proposta de Emenda Constitucional 215 transfere a competência da União na demarcação das Terras indígenas para o Congresso Nacional. A proposta também possibilita a revisão das Terras já demarcadas. Outra mudança seria nos critérios e procedimentos para a demarcação destas áreas, que passariam a ser regulamentados por lei, e não por decreto com é atualmente.
} 
ocorreu em meio a muitos conflitos com os pretensos proprietários da região, demandando forte pressão sobre o poder público da FUNAI, sobre as lideranças indígenas e os demais atores envolvidos.

É importante recordar que a homologação foi realizada sem a identificação das áreas utilizadas para atividades produtivas e indispensáveis para reprodução física e cultural. Esse estudo ocorreu antes da Constituição de 1988 que assegurou tais direitos aos indígenas. Portanto, entende-se que é necessário realizar novos estudos com base nas leis vigentes, com intuito de garantir o que é previsto na Constituição. Segundo o artigo 231:

São reconhecidos aos índios sua organização social, costumes, línguas, crenças e tradições, e os direitos originários sobre as Terras que tradicionalmente ocupam, competindo à União demarcá-las, proteger e fazer respeitar todos os seus bens.

Desse modo, a garantia sobre as Terras tradicionais se transforma em ponto central dos direitos indígenas, ela tem um valor de sobrevivência física e cultural. Não se logrará garantir o direito aos índios, se não Ihes forem asseguradas a posse permanente dos recursos naturais e das Terras por eles ocupadas. Portanto, as disputas dessas Terras e, de sua riqueza, constituem o núcleo dos conflitos envolvendo indígenas no Brasil hoje.

Nos relatórios desenvolvidos pela FUNAI, o termo utilizado para se referir à área que será ampliada é Terra. Como já exposto aqui, esse conceito é empregado a uma parcela da área que é demarcada. No caso da Terra indígena Tenondé Porã há a junção de diversas aldeias em uma extensão contínua, o que se configura como uma possibilidade de intercâmbio entre as aldeias, pois as demais Terras indígenas da Serra do Mar passarão a compartilhar os limites territoriais com a Terra da Tenondé Porã.

Ainda que a FUNAI e o Estado refiram-se a área indígena como Terra, para as comunidades, essa ampliação garantiria aquilo que eles consideram como um fragmento do território Guarani. Essa conclusão é baseada nos próprios relatos Guarani sobre a diferença dos conceitos. Segundo Adriano 6 (2013, entrevista), 
em relação à Terra atualmente demarcada e o projeto de ampliação: "Agora vai ser um território, agora não vai ser uma Terra indígena, vai ser um território".

Outra instituição atuante, além da FUNAI e do CTI, na questão dos direitos indígenas é a Comissão Pró - Índio (CPI), organização não governamental fundada em 1978, em decorrência do contexto de ditadura militar. A organização tem atuado junto com índios e os quilombolas na garantia dos direitos territoriais, culturais e políticos. Atualmente, a comissão tem divulgado um significativo material cartográfico e bibliográfico relacionado à questão das Terras e territórios indígenas e quilombolas, desenvolvendo, também, estudos de manejo e educação indígena. 


\section{CAPÍTULO II:}

\section{MOBILIDADE ESPACIAL E REALIDADE ATUAL DOS GUARANI}

Este capítulo tem por objetivo abordar, de forma geral, o contexto histórico, social e cultural da comunidade Tekoá Tenondé Porá, bem como sua presença no território de ocupação tradicional Guarani. As questões fundiárias, a mobilidade e a fragmentação do território, bem como a retomada a partir de novas ocupações permitem compreender as espacialidades dos grupos, pautada em uma lógica de ocupação do território que tem relação com questões culturais que são profundamente diferentes da lógica de ocupação dos colonizadores e da sociedade contemporânea. 


\title{
2.1 MOBILIDADE ESPACIAL DOS GUARANI
}

\author{
A Terra não pertence ao homem: é o homem que pertence à \\ Terra, disso temos certeza (Cacique Seatle).
}

Os Guarani são uma sociedade de caçadores-coletores e agricultores de coivara, que ocupam um espaço significativo do território nacional e internacional. Estendem-se desde o estado do Espírito Santo até o Uruguai, Argentina e Paraguai. Portanto, seu território de ocupação tradicional abrange significativa área.

As estratégias retóricas para legitimar ações contra os grupos indígenas são múltiplas. No princípio da ocupação territorial do Brasil e da América do Sul, os colonizadores os denominaram de "idólatras" e "infiéis", realizadores de culto ao demônio. Durante o século XVII, no afã ilustrado, eles foram chamados de "bárbaros" e "selvagens". Em geral, essa visão eurocêntrica, tende a invalidar as práticas sociais, culturais e epistêmicas provenientes desses grupos.

As populações indígenas já existiam, obviamente, antes da chegada dos portugueses. Aliás, foram os "brancos" ${ }^{33}$ que denominaram os povos originários das Américas de "índios". Com a chegada do homem "branco", os índios se tornam "estrangeiros" em suas Terras, enquanto os recém-chegados se tornam os "donos" de todo território.

${ }^{33}$ Denominação para os não índios. 
Figura 15: PRESENÇA GUARANI NA AMÉRICA DO SUL

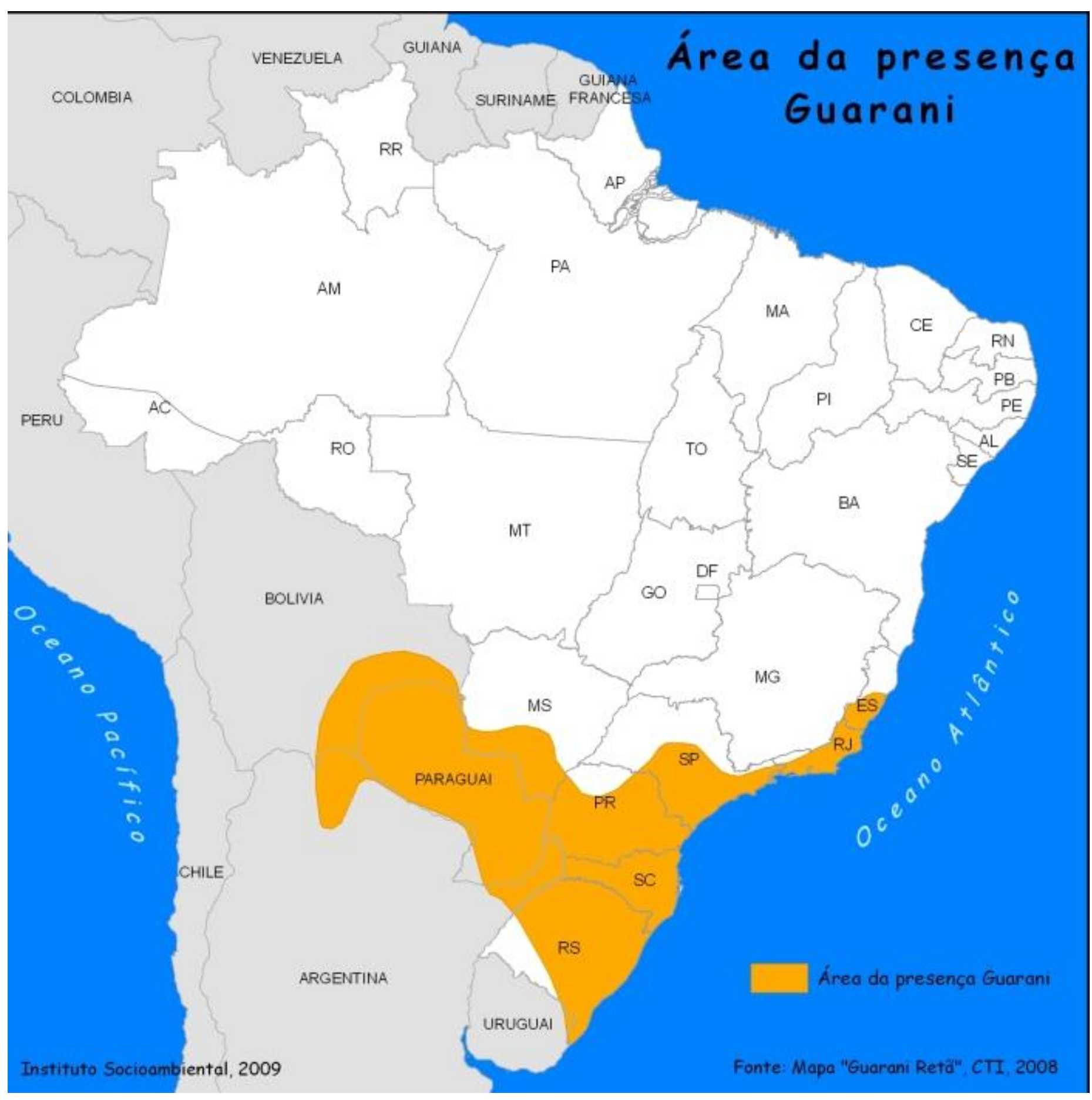

FONTE: Centro de Trabalho Indigenista ${ }^{34}$.

${ }^{34}$ www.trabalhoindigenista.org.br. 
No século XVI os Guarani estavam presentes na área compreendida entre o Chaco e o Atlântico. Eles habitavam as florestas tropicais e subtropicais ao longo do litoral e entre os principais rios do sistema Paraná-Paraguai. Pressionados pelo avanço da colonização, as matas foram o principal reduto desses povos (OTERO, 2011).

Os índios Guarani pertencem à família linguística tupi-Guarani, do tronco Tupi. Eles se dividem em Mbyá, Nhandewa e Kaiowá e, antes da chegada dos europeus, habitavam o espaço que hoje conhecemos como Argentina, Brasil, Paraguai e Uruguai. No Brasil, atualmente, vivem nos Estados do Rio Grande do Sul, Santa Catarina, Paraná, São Paulo e Mato Grosso do Sul, somando aproximadamente 34 mil índios (OTERO, 2011). Na TI Tenondé Porã viviam, em dezembro de 2009, 824 indígenas.

Os Guarani (Kaiowa, Mbyá e Nhandeva) totalizavam em 2008 aproximadamente 145.500 indivíduos, dispersos entre Brasil (50 mil), Paraguai (53,5 mil) e Argentina (42 mil). Os Guarani das regiões sul e sudeste do Brasil, onde se insere a TI, totalizam cerca de 10 mil indivíduos que formam uma intensa rede ligada por laços de parentesco, trocas de bens e xamanismo. Nessas regiões, distribuem-se atualmente em cerca de 150 localidades nos Estados de Rio Grande do Sul, Santa Catarina, Paraná, Rio de Janeiro e Espírito Santo. Na TI Tenondé Porã, viviam em dezembro de 2009, 824 pessoas. (DOU, 2012, p 19)

É importante pontuar que qualquer quantificação realizada desses grupos é imprecisa e duvidosa, haja vista a própria mobilidade Guarani entre as aldeias. Isso impossibilita localizar precisamente o número de Guarani no tempo e no espaço, dificultando a confecção de mapas que tem como variável população indígena. Outro fator que contribui para a imprecisão desses dados é a aversão desses grupos a recenseadores e pesquisadores que visam coletar informações sobre cultura, território e população. Maria Inês Ladeira (2008, p. 63), ao trabalhar com questões diferentes etnias no Brasil e estudar especialmente os povos Guarani, fez esta análise: 
Há unanimidade entre os autores quanto às dificuldades de quantificar os Guarani (Sardi, Melià, Brighrnti, entre outros). Na realidade, entendendo que o território desse povo indígena compreende todas essas regiões, e isso implica em uma dinâmica social em que a mobilidade é inerente (como veremos adiante), tecnicamente é quase impossível contar os indivíduos, a não ser que em todas as aldeias, em todos os países e regiões, em um mesmo dia, concomitantemente, fosse realizado o censo da população, identificando os indivíduos de cada subgrupo, o que seria impossível. Ainda assim, há outras variantes, entre as quais: problemas de acesso a algumas aldeias ou moradias, dificuldades de obtenção de informação nas comunidades, além da aversão dos Guarani aos recenseadores, pois entendem, com razão, que a contagem trata-se de uma forma de controle do Estado, conforme apontado por Melià (1997), no Paraguai, e Brighenti (2001), na Argentina. Desse modo, levantamentos demográficos realizados isoladamente em algumas aldeias, ou mesmo informações numéricas desconectadas no tempo, prestam-se mais a desinformações e projeções infundadas do que benefícios aos Guarani.

Segundo Ladeira e Azanha (1988, p.15), os Guarani Mbyá, da região sul de São Paulo, "descendem daqueles grupos que não se submeteram aos encomenderos espanhóis e, tampouco, às missões jesuítas, refugiando-se nos montes e nas matas subtropicais da região do Guairá dos Sete Povos".

$\mathrm{Na}$ área de presença Guarani, como observado na figura 15, há uma grande concentração de comunidades Mbya e Chiripa. Eles ocupam os territórios onde viveram seus ancestrais Carijo, até meados do século XVII. Essa região é a espinha dorsal da história e mitologia dos povos Guarani, uma vez que eles ainda conservam seus "nomes Guarani”, topônimos que se referem à caracterização geográfica e a cosmovisão sobre o espaço (LITAIFF, 2009). Segundo Adriano (2016, entrevista):

O território tradicionalmente ocupado corresponde aos estados de Espírito Santo, Rio de Janeiro, Paraná, São Paulo, Santa Catarina, Rio Grande do Sul, toda essa área é um território tradicionalmente ocupado. Meu avô disse que nós sempre moramos nessa região, isso tá ligado à crença da "Terra sem males", que não está ligado a Terra, mas ao mar. Território Guarani é toda essa região, aqui é só um pedaço, um fragmento, é uma demarcação dentro do 
território. Só para você ter outra ideia, os Guarani também estão em outros países como Argentina e Paraguai. Tivemos recentemente um encontro continental justamente para discutir essa questão da livre circulação nessa região, que até agora nós não temos (ADRIANO, entrevista concedida).

A partir da década de 1940, de acordo com estudos apresentados por Ladeira e Azanha (1988), a região da Serra do Mar foi alvo de posseiros ${ }^{35}$. Essas Terras seriam objeto de alianças entre indígenas e especuladores visto que, em troca de proteção, os tais "proprietários" passam a ser reconhecidos como "senhores" das Terras ocupadas. Na década de 1970, com a construção da rodovia Rio-Santos, a especulação imobiliária cresce de forma desordenada. O loteamento do entorno do Parque Estadual da Serra do Mar chega, nesse período, a circundar as Tls da Comunidade Tenondé Porã e Krukutu, fazendo com que a relação estabelecida anteriormente entre indígenas e brancos fosse rompida, levando os Guarani a defenderem suas Terras, como relata Laderia (1988, p. 5).

[...] Praticamente todas as áreas Guaranis passaram, a partir dos anos 70 , a ser alvo de cobiça e de sucessivas invasões. Se, até a década de 50, os Guarani não tinham o que temer dos seus "aliados brancos" (os pretensos proprietários), nos anos 70 a especulação imobiliária forçará o rompimento dessa aliança, levando os Guarani a defenderem suas posses.

$\mathrm{Na}$ década de 1980, com a criação do CTI (Centro de Trabalho Indigenista), foram elaborados mandatos e ações judiciais para que as diversas Terras indígenas da região Sul de São Paulo, incluindo Tls da área da Barragem Tenondé Porã e Krukutu fossem reconhecidas e demarcadas. O processo de demarcação se deu em meio a fortes pressões dos ditos "proprietários" da região. O cenário de conflitos e pressões na década de 80 foi pouco explorado por pesquisas, tendo somente os relatos e trabalhos apresentados por Ladeira (1988;

\footnotetext{
${ }^{35}$ É necessário pontuar que não é nosso objetivo discutir os aspectos históricos da ocupação da Serra do Mar, e nem mesmo as terminologias relacionadas, como: posseiro, proprietário, grileiro e ocupante, visto que existem trabalhos que se dedicaram a esse tipo de análise, como o próprio trabalho desenvolvido por Maria Inês Ladeira.
} 
1992) e o Centro de Trabalho Indigenista (CTI), o que inviabiliza a abordagem desses conflitos de forma mais aprofundada e quantitativa.

A região que conecta o litoral com a região sul de São Paulo sempre foi trânsito obrigatório dos grupos Mbyá. As várias famílias Mbyá permaneceram e ocuparam, por tempo indeterminado, locais estratégicos dessa região. Por esse motivo, na cosmologia Guarani, essa região representa um lugar sagrado a ser preservado e ocupado por eles (LADEIRA e AZANHA, 1988).

A mobilidade dos Guarani é marcada pelo constante intercâmbio de suas tradições e cultura com as diversas comunidades instaladas no Sul e Sudeste do país. Os pajés e os demais membros da comunidade costumam compartilhar e buscar o conhecimento Guarani por meio do contato com outras realidades. Essa troca se dá em diferentes aldeias, o que permite aos Guarani entrar em contato com outras paisagens de fauna e flora (ADRIANO, 2015, entrevista).

Antes mesmo de ter essa nova delimitação, por exemplo, nós íamos andando até Rio Branco, Itanhaém, para nós não existe isso de não poder ir. As outras aldeias não acham ruim, então a gente sempre anda, não existe divisão entre as aldeias, e também não existe isso de não poder entrar em alguma Terra.

O conhecimento é visto pelos Guarani como uma prática contínua de contato com a natureza. As crianças das aldeias são levadas até outras comunidades para conhecer e aprender na prática como plantas tradicionais são utilizadas em outras áreas. Da mesma forma, o deslocamento até outras comunidades possibilita às crianças conhecerem diferentes espécies de animais que, por conta do espaço limitado e do avanço do desmatamento, não são comumente encontrados na aldeia de origem. O contato com a natureza é considerado um meio para o processo de aprendizagem das crianças Guarani. Antes de aprender a ler e a escrever, elas são ensinadas a observar o conhecimento do mundo que as envolve (LADEIRA, 2004). Essa realidade é constatada na fala de um Guarani. 
[...] Nós temos ligação com muitas comunidades, aliás, existe um fluxo contínuo de pessoas que vão morar em outras aldeias e outras pessoas que vem para esta aldeia. Eu, por exemplo, faz 10 anos que estou na Tenondé Porã. Essa mobilidade entre nós é contínua. Os jovens da aldeia devem ir para outras aldeias para conhecer outras realidades, muitas vezes é importante que eles possam ir para conhecer plantas, árvores e animais da natureza que não existem mais aqui nessa área (ADRIANO, 2013, entrevista concedida).

O conceito de "mobilidade" talvez não seja capaz de exprimir essa constante caminhada dos Guarani em busca de um território propício para a existência de sua cultura. Possivelmente, seja, então, um conceito que exprime uma face da territorialidade Guarani. Porém, como tantos outros aspectos da cultura que carecem de equivalência em diferentes línguas, a palavra mobilidade tenta expressar essa dinâmica espacial tão particular aos Guarani, na visão da sociedade atual. Ladeira (2008, p. 114) afirma que:

Pode-se dizer que os Guarani procuram viver e formar aldeias, elegendo lugares com os quais se reconhecem, onde pode reproduzir os elementos e as condições que lhes permitam pertencer. Em outras palavras, pode-se dizer que não são os lugares que lhes pertencem, mas eles que pertencem aos lugares.

Com o avanço do desmatamento e do confinamento das comunidades, os elementos que tradicionalmente constituiriam o espaço físico de um território indígena, muitas vezes não existem. Desse modo, as comunidades se veem obrigadas a se adaptar às novas realidades, e acabam desenvolvendo diferentes estratégias para a reprodução da cultura. $O$ desmatamento também interfere na fauna e na flora das aldeias, causando a extinção e a diminuição do número de espécies características da Mata Atlântica, por exemplo.

A mobilidade, característica dos Guarani, só é possível se perpetuar no tempo e no território se houver garantias em relação às parcelas de Terra, bem como, uma constituição territorial que garanta a reprodução de seu modo de vida característico, possibilitando aos Guarani galgar, cada vez mais, autonomia em 
relação às políticas assistencialistas governamentais que hoje são recorrentes nas comunidades.

\subsection{Questão fundiária Guarani}

O território é tudo, se nós não temos um território nós não temos nada. $\mathcal{E}$ essa base que possibilita a nossa interação com a natureza $(\mathcal{A D} \mathcal{R} I \mathcal{A} \mathcal{N O})^{36}$

Como disse Adriano, o território é tudo e, se ele é tudo, sua ausência representa o nada, o vazio que impera quando uma comunidade é destituída de seu território. Portanto, entende-se que é a partir dele que os questionamentos devem ter início. Essa visão Guarani do território possibilita a realização de diferentes leituras sobre esse conceito, tão diverso nos seus contextos específicos de apropriação.

$\mathrm{Na}$ área de estudo, encontra-se o território material e simbólico da comunidade Guarani Tenondé Porã, sobreposto à APA (Área de Preservação Ambiental) Capivari - Monos e ao Parque Estadual da Serra do Mar (PES). A Terra Indigena $(\mathrm{TI})^{37}$ Tenondé Porã, na década de 70 , era denominada de Vila Guarani. Posteriormente, na década seguinte, foi chamada de Morro da Saudade. Atualmente, é conhecida como Tenondé Porã, sendo a fusão entre as Terras do Krukutu e Morro da Saudade (FARIA, 2016).

A sobreposição existente entre a Terra indígena da Tenondé Porã e o Parque Estadual da Serra do Mar é de 45\%, com a APA Municipal Capivari-Monos é de 31\%. A sobreposição simultânea da Terra é de 14\% (FUNAI, 2014). Portanto,

${ }^{36} \mathrm{Em}$ diferentes momentos do trabalho de campo, Adriano foi indicado como responsável pela recepção e acompanhamento dos pesquisadores que realizam trabalhos na comunidade. Depoimento colhido.

${ }^{37}$ Terra Indígena 
apenas $24 \%$ da Terra indígena não tem sobreposição com as áreas destinadas à conservação, segundo critérios estabelecidos pelo sistema nacional de unidades de conservação (SNUC). Tem-se, também, a sobreposição da Terra indígena Tenondé Porã com 149 propriedades privadas, fruto do loteamento ilegal das áreas, segundo estudo fundiário realizado pela FUNAI e por outros pesquisadores (FARIA, 2016). Além de tudo a Terra Indígena Tenondé Porã tem diversos empreendimentos de infra-estrutura que impactaram a comunidade, como apontou estudo da Comissão Pró- Índio ${ }^{38}$.

${ }^{38}$ Para saber mais sobre o assunto consultar site da Comissão Pró Índio em: http://cpisp.org.br/indios. 
Figura 16: TERRAS INDÍGENAS E EMPREENDIMENTOS DE INFRAESTRUTURA

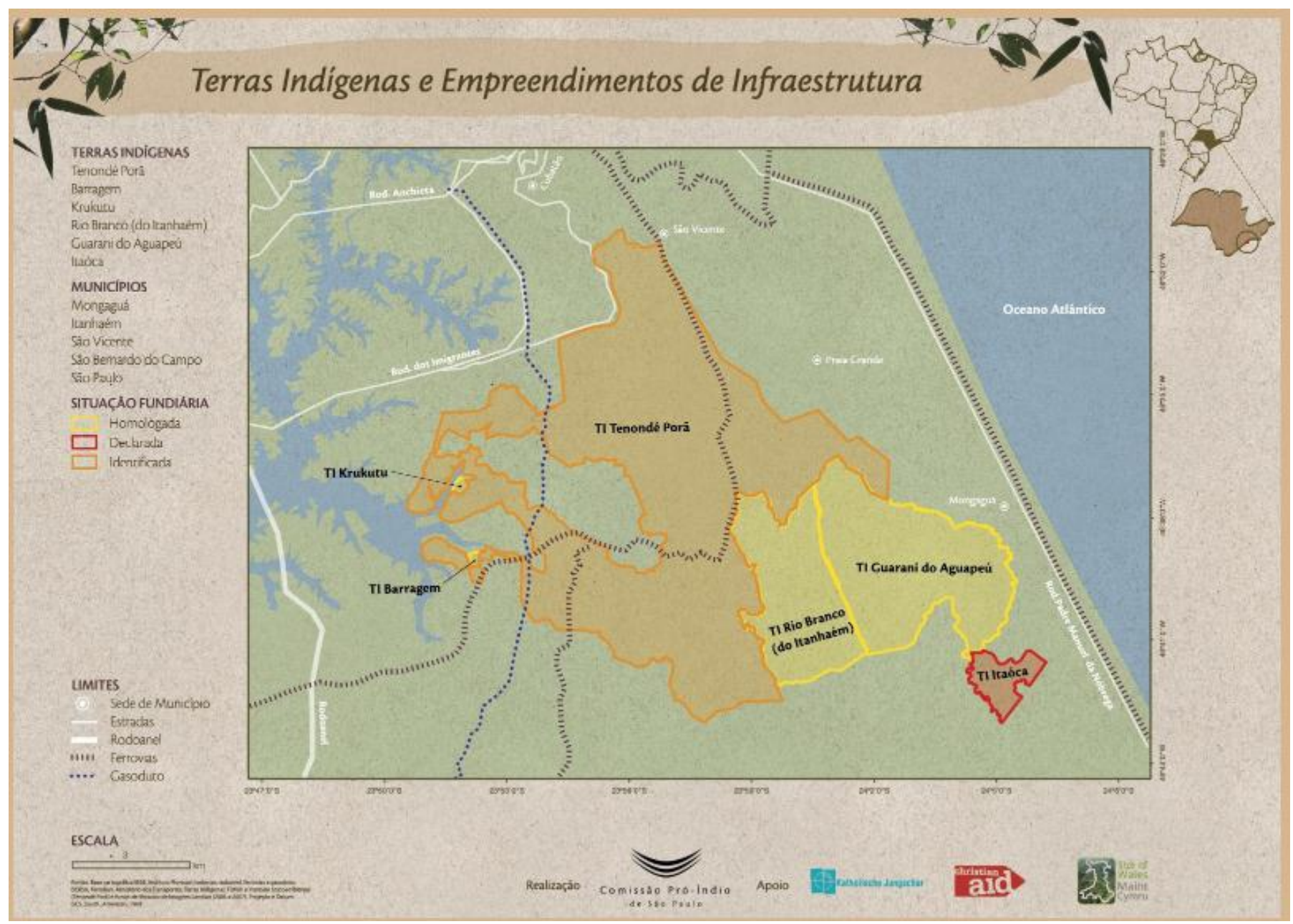

Fonte: Comissão pró-índio (2012). 
O ponto problemático do trabalho com o conceito de território é a sua adoção como sinônima de Terra indígena. No caso em estudo, a Terra indígena é um área ilhada, fragmentada e incapaz de suprir as necessidades básicas de sobrevivência das comunidades, contendo somente o núcleo habitacional demarcado. Essa ideia está presente na discussão sobre a adoção do conceito território para denominar, na verdade, as Terras indígenas, questão levantada por Maria Inês Ladeira (2008).

A pesquisadora desenvolve sua tese de doutorado a partir da noção de espaço geográfico Guarani, em análise que abrange as Terras Guarani da região sul, sudeste e centro oeste do Brasil. Tal abordagem escalar difere escala geográfica adotada nesta pesquisa, que engloba apenas 5 Terras indígenas localizadas na Serra do Mar em São Paulo, Mongaguá e parte de São Bernardo dos Campos.

A primeira constatação sobre a sobreposição é que, diferente de muitos cenários onde esse quadro gera conflitos intensos, como no caso dos povos Guarani do Mato Grosso, no caso do território Guarani da Serra do Mar, segundo as lideranças da Tekoá Barragem, não há conflitos intensos com a gestão do Parque Estadual da Serra do Mar até o presente momento.

No entanto, em meados de 2013 ocorreram ataques realizados contra a tekoá Kalipety, não foi identificado o autor dos ataques, visto que a área era usada para desmonte de carros, segundo relatos de moradores da região. Segundo os indígenas da aldeia Tenondé Porá "Mais uma vez invasores tentam nos amedrontar para abandonarmos nossa Terra, mas vamos ficar" ${ }^{39}$. Essas retomadas de áreas que foram aldeias permanentes e transitórias Guarani, em outros momentos, fazem parte da dinâmica de circulação das comunidades,

\footnotetext{
${ }^{39}$ Fala retirada da reportagem publicada no site: www.periferiaemmovimento.com.br acesso dia: 24/08/2017
} 
principalmente dentro de um contexto ao qual os Guarani estão inseridos, ou seja, confinados em apenas um núcleo habitacional, o Tenondé Porá.

Adriano (2016, entrevista) afirma que a proposta de ampliação dos limites da comunidade teve como fundamento a tentativa de reduzir a quantidade de sobreposição das comunidades com propriedades privadas, com o intuito de minimizar os possíveis conflitos e acelerar o processo de consolidação da demarcação. Segundo Adriano (2016, entrevista).

A princípio eu não sei se existe algum conflito, de alguém reclamar abertamente dizendo que os índios ou a FUNAI pegou uma área nossa. Tomou-se o maior cuidado nessa nova delimitação para não pegar muitas sobreposições, até mesmo para não atrasar mais ainda os trabalhos, pois como este estudo já estava atrasado, preferiu-se não ter sobreposições sobre sobreposições.

Camila Faria (2016) constatou somente um processo judicial relacionado à reivindicação de Terra por um proprietário privado ${ }^{40}$. Segundo o relatório de identificação da TI Tenondé, produzido pela FUNAI, após ampliação haverá 149 ocupantes não indígenas, pois antes disso não haveria sobreposições devido ao fato de se tratar somente do núcleo habitacional.

Dentre as 149 ocupações identificadas, 53 são de posseiros, 25 são de ocupantes que alegam ter títulos e 17 são de permissionários. [...] Em 3 casos foi possível verificar a titulação por meio de processo de usucapião, que se realizou sem a consulta prévia à FUNAI, para verificar a possível incidência em área de ocupação tradicional indígena, o que pode ter ocorrido em mais casos que não pudemos verificar. Nos outros casos, trata-se em sua maioria de propriedades nas quais caseiros ocupam a área, e os proprietários não as frequentam ou visitam-nas apenas esporadicamente, conforme se pode verificar a partir das vistorias. Pode-se notar que o levantamento fundiário reflete em muito o histórico de esbulho progressivo contra a ocupação tradicional indígena, caracterizado nesse capítulo e na Parte I desse relatório, uma vez que o a TI foi invadida a partir das sucessivas levas de colonização mencionadas anteriormente, a despeito da constância

\footnotetext{
${ }^{40}$ Consultar tese de doutorado Camila Salles Faria (2016).
} 
da presença Guarani na região (Diário Oficial da União, 2012, p. 19).

Esclarecendo melhor essa tipificação, entende-se que os 53 posseiros são pessoas que contém, na prática, a posse de uma porção de Terra, mas não são donos da Terra, ou seja, não tem documentação nem registro no cartório ${ }^{41}$. Entende-se por proprietário aquele que possuí documentos que comprove sua posse sobre a Terra, no entanto, grileiros são aqueles, em grande maioria, que utilizam a violência para se apropriar de Terras devolutas ${ }^{42}$, Terras indígenas ou Terras trabalhadas por posseiros. Por fim, permissionário são aqueles que obtiveram licença para ocupar ou usufruir determinada área.

Faria (2016) constata, ao levantar e analisar as cadeias dominiais de diversas Terras indígenas, que no caso da TI Tenondé Porã, assim como em outros casos, que há fortes indícios de grilagem e apropriação privada de Terras públicas ${ }^{43}$.

Em suma, o que se observa é que nenhuma das cadeias dominiais apresentadas tem como origem um bem público, ou mesmo a chancela do Estado de títulos de posse, ou ainda a indicação da legislação que as legitime ao longo da história brasileira desde as concessões promovidas pelo governo de Portugal, as sesmarias confirmadas, por exemplo. Constituindo, assim, indícios de que houve na origem a apropriação privada de Terras públicas (devolutas ou não), ou seja, a grilagem de Terras públicas, a qual foi se legitimando com a "constituição" da propriedade privada. (FARIA, 2016. p. 211)

A adoção do conceito de território, nesse caso, é central, pois reforçará a reivindicação da incorporação da área de pesca, caça, coleta e plantação, não somente a demarcação da área referente ao núcleo habitacional, tal como foi feito nas 5 comunidades, pois essas demarcações só levaram em consideração 0 núcleo habitacional. Caso ocorra a ampliação da Terra indígena, este passará a ser um território, pois será uma das maiores Terras indígena do estado de São

${ }^{41}$ Definições do dicionário Aurélio.

42 Terras devolutas são Terras públicas.

${ }^{43}$ Para maior detalhamento da cadeia dominial das Terras Guarani consultar tese de Camila Salles Faria (2016). 
Paulo, com possibilidade de desenvolvimento do modo de ser tradicional. Para entender melhor essas questões, é interessante apresentar os resultados da pesquisa na qual Ladeira (2008) aponta elementos que já foram considerados:

Para algumas Terras indígenas na Amazônia, que passaram a corresponder ao território atual do grupo indígena, a associação entre Terra e territórios, embora propiciadora de um maior controle do Estado sobre o grupo indígena, pode não ser tão nefasta. No entanto, nas regiões Sudeste/Sul, as Terras de um mesmo grupo indígena situam-se em diferentes localidades não contínuas e entremeadas das mais variadas formas de ocupação humana. Portanto, a vinculação do significado de território aos limites da Terra demarcada desloca-se de seu próprio contexto territorial. Essa ilusão induzida, de a Terra se consistir no território indígena, leva a sociedade nacional a crer na necessidade de ainda maior confinamento das populações indígenas no interior das Terras demarcadas e ao desconhecimento eficaz da existência de outras territorialidades. No âmbito das políticas publicas as Terras indígenas - sobretudo no sul, Sudeste, Nordeste e no Mato Grosso do Sul - são tratadas como "ilhas" isoladas, como fragmentos de um "antigo território", desfigurado, asfixiado e retalhado pelos mesmos agentes e fatores que produziriam essas categorias. Com relação à sociedade Guarani, a redução do conceito de território aos limites das Terras demarcadas, além de totalmente impróprio, produz maiores conflitos e questionamentos (LADEIRA, 2008, p. 89).

Portanto, pontua-se que não há uma redução do conceito de território aos limites da Terra indígena, na verdade, há uma situação singular no caso das comunidades Guarani da Serra do Mar, ou seja, a necessidade e a viabilidade de se unir a área de 5 comunidades que passarão a compartilhar os mesmos limites administrativos o que se configurará em uma situação fundiária específica, um território de uma extensão que até então é inexistente dentro do estado de São Paulo, por exemplo.

Segundo Adriano (2016, entrevista) com a ampliação da Terra atual e incorporação das demais Terras é possível falar em um fragmento do que seria o território Guarani, pois "Com a ampliação da Terra atualmente demarcada nós teremos parte do nosso território, pois o território é algo muito mais amplo que abrange áreas de outros países". 
Por isso, mesmo que a definição administrativa proposta de Terra indígena (TI) esteja juridicamente separando as aldeias das terras indígenas Itaóca, Rio Branco e Tenondé Porã, compreende-se que quando se fala em território Guarani, faz-se referência a esse território unificado, ampliado, posterior a consolidação da ampliação da demarcação, o que ainda não ocorreu. Para Adriano (2016, entrevista) é importante frisar a diferença entre Terra e aldeia, pois é necessário observar que os recortes territoriais são diferentes e falar de território implica entendê-los:

A diferença entre aldeia e Terra indígena é que dentro de uma Terra indígena você pode ter diversas aldeias com cacique e organização própria, agora a aldeia é só um pedaço, por exemplo, a aldeia indígena Tenondé Porã tinha só 26 hectares, não tinha como ter mais, diferente de uma Terra indígena.

Segundo Adriano ${ }^{44}$, (2013, entrevista) a ampliação abrangeria parte de outros municípios e aldeias, unificando as fronteiras jurídicas entre outras Terras indígenas. Portanto, a formação de um fragmento do território Guarani é possível, embora juridicamente o Estado defina como Terras e não como território:

[...] essa Terra que será ampliada, esse espaço, vai abranger a outra aldeia, a do krukutu, vai pegar um pedaço de São Bernardo, Cubatão, Mongaguá, Praia Grande e Itanhaém. Agora vai ser um território, agora não vai ser uma Terra indígena, vai ser um território. Igual a do Xingu, em um mesmo território vai ter várias aldeias e várias etnias. Vão se juntar várias aldeias da baixada nesse novo território [...] (ADRIANO, 2013).

Assim, como aponta Bruce Albert (2002) a respeito da apropriação do conceito de Terra pelos povos indígenas da Amazônia, que este é reorientado para os interesses das comunidades. No caso das aldeias da Tenondé Porá, o mesmo sentido é empregado, como forma de resistência e permanência na Terra, pois mesmo que juridicamente com a ampliação o Estado e a FUNAI utilizem a

\footnotetext{
${ }^{44}$ Guarani é Guarani mbyá e professor - coordenador na área de educação do Centro de Estudos de Cultura indígena (CECI), escola Municipal localizada dentro da comunidade Tenondé Porã.
} 
terminologia Terra, para os Guarani é uma conquista a ampliação da Terra, representando um fragmento do que seria um território Guarani da Serra do Mar.

Para além da diversidade dentro das características ecológicas e das coordenadas histórico-simbólicas dos espaços que ocupam, os "índios" referem-se unanimemente à categoria genérica de "Terra indígena" herdada do código jurídico da sociedade envolvente, mas reorientada como condição política de resistência e permanência de sua especificidade social (ALBERT; 2002, p. 240)

Pode-se concluir com esse tópico que a realidade atual das Terras indígenas localizadas na Serra do Mar é bastante complexa, visto que envolve questões fundiárias diversas.

Ao observar o histórico de ocupação dessa área e, como FARIA (2016) salientou, sobre os processos e cadeias dominiais relacionadas, constata-se que os povos Guarani sempre ocuparam essa área, sendo um território indispensável e fundamental para troca, pesca, coleta e circulação, remetendo aos processos históricos de mobilidade desses povos e de garantia dos direitos fundamentais.

\subsection{A FRAGMENTAÇÃO E A RETOMADA DOS TERRITÓRIOS GUARANI}

Em meados dos anos 1990 Oliveira (1989, p.27 apud HOFFMANN, 2010, p 48) já apontava a relação paradoxal existente na visão Guarani sobre seu território. Em seu trabalho ele problematiza a questão das fronteiras como uma imposição dos contextos históricos aos quais os povos Guarani foram submetidos. Portanto, a fragmentação desse território também se deve a imposição das fronteiras.

A relação entre uma sociedade indígena e seu território não é natural ou de origem. Não é da natureza das sociedades indígenas 
estabelecerem limites territoriais precisos para o exercício de sua sociabilidade. Tal necessidade advém exclusivamente da situação coloniais a que essas sociedades estão submetidas.

Se no primeiro momento a fronteira é uma imposição, no segundo, ela passa a cumprir um papel fundamental na garantia de direitos, como substrato material necessário à reprodução dos povos indígenas. Portanto, é importante esclarecer que, para os povos indígenas, o entendimento sobre fronteira é complexo e deve ser problematizado, pois contém uma definição variável devido às condições históricas e sociais que os povos indígenas foram e ainda são submetidos.

Nesse tema, há críticas relevantes feitas aos mapeamentos participativos que tentam reduzir as espacialidades indígenas, resultado das vivências comunitárias, em territórios delimitados por limites do tipo fronteira. É o que aponta Hoffmann (2010, p. 72) sobre os mapeamentos participativos:

Também se tem chamado a atenção para o fato de que a fixação de grupos étnicos a territórios delimitados a partir das fronteiras estabelecidas em processos de mapeamento participativo pode criar conflitos antes inexistentes, quando as fronteiras eram mais fluidas e possibilitavam a vinculação de vários grupos dentro de uma mesma área.

Em função do intercâmbio de mercadorias e conhecimentos, o que fortalece a identidade cultural e territorial do grupo, a mobilidade, como abordado anteriormente, também pode ser pensada como uma ação sobre o território que se apresenta como um ato de contestação de limites absolutos, pois se mover sobre o território é fortalecer laços culturais e políticos, subvertendo os limites administrativos / jurídicos. Assim como aponta Adriano (2016, entrevista):

A gente não conhece na nossa tradição, divisa, fronteira, limite; ou mesmo colocar uma placa dizendo "essa Terra é minha", mas também depois da invasão a gente aprendeu a lidar com isso. Agora nós sabemos diferenciar, "aquilo é meu, aquilo é dele", mas dentro da nossa aldeia, por exemplo, a gente não tem essa história de divisão. Antes mesmo de ter essa nova delimitação, por 
exemplo, nós íamos andando até Rio Branco, Itanhaém, para nós não existe isso de não poder ir. As outras aldeias não acham ruim, então a gente sempre anda, não existe divisão entre as aldeias, e também não existe isso de não poder entrar em alguma Terra.

$\mathrm{Na}$ prática, essas comunidades já estabelecem intercâmbios constantes que não se limitam à convivência das parcelas de Terras demarcadas. Essas fronteiras são móveis e dinâmicas, extrapolando os limites físicos determinados pelas demarcações, conforme se abordou anteriormente.

A questão central colocada hoje pela comunidade tem relação com a falta de uma área suficientemente adequada ao desenvolvimento das atividades características da cultura Guarani. A inexistência de um território adequado, além de causar feridas identitárias, convergindo com os chamados processos de etnocídio e genocídio, já assinalados pelo antropólogo Pierre Clastres (2004; 2010), também coloca os povos indígenas na condição de tutela do Estado, suprimindo os fragmentos de territórios que historicamente são o suporte tanto da cosmovisão indígena, quanto dos últimos redutos de remanescentes florestais do Brasil, contidos nessas áreas ${ }^{45}$.

A relação do Estado brasileiro com a questão indígena sempre foi controversa. O Estado promove e corrobora sistematicamente com o genocídio e o etnocídio da população indígena, mas, ao mesmo tempo, cria órgãos (Superintendência de Proteção ao Índio, Fundação Nacional do Índio) para promover sua proteção, amparando-os em leis específicas (Constituição Federal de 1988). Na lógica de produção capitalista, os povos indígenas sempre representaram um obstáculo ao desenvolvimento. Como apontou na década de 80 a socióloga Durham (1982, p. 48), esse cenário de violência e tutela pouco, ou nada, se modificou ao longo de 40 anos, já que há uma continuidade nas políticas de manutenção da dependência desses grupos, e um desrespeito sistemático às garantias conquistadas no formato de leis:

45 Atualmente, uma grande parcela dos remanescentes florestais está contida em Terras indígenas. 
A contradição que isso cria em relação aos interesses econômicos efetivamente representados no Estado tem sido resolvido, na prática, através do subterfúgio de reconhecer direitos formais e permitir seu desrespeito sistemático: ideologicamente, através da elaboração de uma teoria de cristianização, civilização ou integração que, defendendo a preservação física dos índios, justifica sua destruição, enquanto sociedade e enquanto cultura, em nome do progresso (DURHAM, 1982, p. 48).

Prova disso é que, mesmo quando há a delimitação da Terra indígena, as comunidades sofrem com a insegurança, já que os limites sempre podem ser contestados. Um bom exemplo é a consolidação do programa de Emenda Constitucional (PEC) $215^{46}$ que prevê a revisão dos estudos, por meio do poder legislativo, de delimitação de Terras indígenas já demarcadas. Essa condição é vivida por todas as comunidades instaladas em Terras demarcadas, uma situação que reforça a tutela dos indígenas ao Estado e a fraca autonomia territorial que deriva dessas relações. Segundo antropólogo que trabalhou diretamente com as comunidades "O que eles propõem é que vários ministérios participem dos estudos de demarcação desde o início. Mas esse é um trabalho muito minucioso, muito técnico, que leva tempo e não pode ser feito sob pressão política". ${ }^{47}$

O Estado confina as comunidades nas suas demarcações para que se reconheça a "identidade" Guarani, o que é contraditório e limitante para as comunidades que estão habituadas a circular pelas diferentes aldeias. Portanto, 0 próprio conceito de território é contraditório se analisado em óticas diferentes como apontou Ladeira (2008, p. 84):

Considerando que o conceito território não é próprio das sociedades indígenas, e que as delimitações territoriais são historicamente fixadas por meio de estratégias de poder e controle política do Estado, conclui-se que os territórios e as Terras

\footnotetext{
46 A Proposta de Emenda Constitucional (PEC) 215 transfere a competência da União na demarcação das Terras indígenas para o Congresso Nacional. A proposta também possibilita a revisão das Terras já demarcadas. A proposta também prevê uma mudança nos critérios e procedimentos para a demarcação dessas áreas, que passariam a ser regulamentados por lei, e não por decreto, como é atualmente.

${ }^{47}$ Depoimento retirado de reportagem apresentada dia 17/04/2014 de www.brasildefato.com.br; acessado dia 24/08/2017.
} 
indígenas são espaços dominados que, inevitavelmente, forçam os índios a firmar um pacto eterno de dependência com o Estado. A dinâmica expropriação <> concessão de Terras e limites, por meio da qual se supõe, ou se induz a crer, estar propiciando aos índios a liberdade e o exercício de gestão (dentro dos limites impostos e fixo), é a contradição inerente e latente do conceito de território indígena e de políticas e legislações indigenistas.

Outra forma de reforçar a tutela estatal sobre os povos indígenas é por meio de políticas públicas que, na sua grande maioria, são precárias e não garantem o desenvolvimento do modo de vida tradicional. Isso significa suprimir uma cultura, já que você subtrai o substrato material necessário ao fortalecimento de uma determinada identidade cultural (território indígena). Porém, a situação é amenizada por meio de fontes alternativas de renda para que não haja contestação, para que não se exija os direitos territoriais garantidos por lei. É o caso das políticas assistencialistas ofertadas pelo governo.

Essas políticas públicas, entendidas como forma de integração da comunidade à sociedade moderna, são: bolsa família, cargos públicos e assistencialismos diversos, pois a partir do momento que se retira o espaço destinado à caça, pesca e coleta de materiais se impede a própria sobrevivência desses grupos, questão que está ligada a redução do conceito de território. É o que aponta FARIA (2008, p. 10).

Os momentos de integração da comunidade indígena ao "mundo" capitalista são decorrentes de políticas públicas e ocorrem de maneira precária, pois efetuaram uma redução de seu território, e uma tentativa de igualá-lo à Terra Indígena (T.I.), espaço produzido pelo Estado que levou em conta somente o espaço de residência da comunidade, sem incluir o espaço de coleta, caça, pesca e plantação.

Uma leitura geográfica do território Guarani passa pelo entendimento do conceito de "Yvy rupa" ${ }^{48}$, termo que, em língua Guarani, designa o território tradicionalmente ocupado por esses povos. Esse conceito é mais abrangente se

\footnotetext{
${ }^{48}$ As traduções dos termos em Guarani apresentados aqui são adaptações, visto que não há uma palavra em português que expresse literalmente o significado dos conceitos.
} 
comparado com outros que tem outra escala espacial, como é o caso do vocábulo "tekoá", para designar aldeia. No entanto, esse termo, de escala abrangente, não deve ser reduzido à ideia de Terra Guarani e nem mesmo ser reduzido ao fragmento de território que aqui se aponta como necessário às comunidades indígenas da Serra do Mar.

A definição jurídica de Terra Indígena (TI) não equivale nem à ideia de Tekoá e nem a de Yvy Rupa. Isso porque, dentro de uma Tekoá podem existir diversas aldeias, como é o caso da TI Tenondé Porã, constituída por seis aldeias.

O território Guarani não está ligado somente às crenças e histórias da mobilidade desses povos no passado, mas, também, pelas relações materiais e simbólicas que criam e recriam o passado no presente e vice e versa. A territorialidade, entendida como modo de vida, é a expressão desse território apropriado, inserindo-se como estratégias de dominação do espaço.

O território tradicionalmente ocupado corresponde aos estados de Espírito Santo, Rio de Janeiro, Paraná, São Paulo, Santa Catarina, Rio Grande do Sul, toda essa área é um território tradicionalmente ocupado. Meu avô disse que nós sempre moramos nessa região, isso tá ligado à crença da "Terra sem males", que não está ligado a Terra, mas ao mar. Território Guarani é toda essa região, aqui é só um pedaço, um fragmento, é uma demarcação dentro do território. Só para você ter outra ideia, os Guarani também estão em outros países como Argentina e Paraguai. Tivemos recentemente um encontro continental justamente para discutir essa questão da livre circulação nessa região, que até agora nós não temos (ADRIANO, entrevista concedida).

Baseado em pesquisas passadas sobre a mesma comunidade se pode verificar também diferentes depoimentos a respeito da própria origem e formação das comunidades da região da Serra do Mar. Segundo Davi Silva (depoimento retirado de LADEIRA, 1992, p. 153):

Quando Nhanderu Tenondé (nosso pai primeiro) construiu esse mundo, ele disse: meus filhos que vão estar no mundo vão ter que se separar e deverão caminhar... Eles andaram para o bem. E se 
separaram cada um com suas companheiras, cada um com suas famílias.

A diferença existente entre a concepção de território Guarani e a lógica capitalista de apropriação do território reside em uma diferença espaço-temporal. A concepção de tempo no modo tradicional Guarani não é a mesma da sociedade contemporânea. Um exemplo da singularização da cultura Guarani em relação ao tempo é a não existência de dias da semana. A forma de organização da vida individual e coletiva Guarani não é a mesma da sociedade moderna, ela não segue um calendário homogêneo. São inúmeros os exemplos capazes de ilustrar como as concepções divergentes de território podem resultar na desterritorialização de populações.

Segundo Ladeira (2008), os conflitos entre índios, conservacionistas e indigenistas no Brasil se intensificaram depois da promulgação da Constituição de 1988, que garante os direitos indígenas sobre a Terra (artigo 231) e a proteção ambiental (artigo 255), já que a maior parte das Terras indígenas está situada em grandes remanescentes florestais. Além do mais, é necessário considerar os conflitos existentes entre indígenas e latifundiários que impulsionam, significativamente, o extermínio desses povos, causando, em muitos casos, o deslocamento forçado.

Outro impasse que reforça o processo de fragmentação do território Guarani são os métodos adotados para se reconhecer a "tradicionalidade" de uma Terra indígena. Há divergências, entre grupos indígenas e as definições jurídicas, em relação à apropriação simbólica e material do território, o que abre precedente para questionamentos, não demarcações e conflitos.

Ladeira (2008, p. 109) aborda outra situação ilustrativa desse descompasso entre as visões, e que interfere diretamente na demarcação de Terras indígenas, pois refere-se a situação já ilustrada da questão dos limites das demarcações das comunidades:

Durante o Processo de Identificação da Área Indígena do Aguapeú, iniciado em dezembro de 1992 (do qual participei como 
coordenadora do grupo de trabalho), a comunidade insistiu para que os divisores naturais - os rios Aguapeú, Bixoro e Mineiro fossem mantidos, retificando uma proposta anterior de área que excluía ocupações antigas de não - índios. Apesar das dificuldades (sobretudo orçamentárias para pagamento das indenizações dos ocupantes não - índios) que retardariam a finalização do processo (que até o momento não se concluiu), os Guarani não desistiram de que fossem mantidos os rios como divisores. A princípio, parecia que tal atitude se relaciona à dimensão da área que, seguindo pelas divisas dos rios, seria muito maior. Entretanto, a preocupação maior dos Guarani era manter "as formas da Terra", isto é, que a área de sua aldeia não fosse tão desfigurada. Diante da deformação de partes do mundo - e em um sentido mais amplo, do próprio mundo (decorrentes das demarcações, cercas, estradas, limites impostos pela sociedade dominante) -, o contorno dos rios e o da Terra pelos rios garantem, além da presença desse recurso, o desenho natural da aldeia.

A fragmentação do território também pode ocorrer devido ao isolamento de uma comunidade em relação às demais da mesma etnia. A articulação, as trocas e o sistema de reciprocidade é o que possibilita o vínculo com o território Guarani. Como já pontuado nesta pesquisa, para os Guarani os limites físicos da aldeia não correspondem à ideia tradicional de território. Quando ocorre o isolamento e a não permissão para se circular livremente entre as diferentes aldeias, há uma redução de toda cosmologia Guarani, como constatou Ladeira (2008). É importante ressaltar que não é pretensão desta pesquisa desdobrar estudos mais específicos sobre esse ponto levantado pela autora, até mesmo porque os objetivos de trabalho são bem diferentes. Mas há de se considerar esse ponto como central para se entender a complexidade do conceito de território, quando pensado, vivenciado e experimentado em contextos culturais diferentes.

O sistema de reciprocidade, envolvendo famílias de diferentes aldeias, acaba definindo o desenho do mundo mbyá. Não basta as aldeias estarem distribuídas, é preciso haver reciprocidade entre os grupos familiares. Uma unidade familiar que se isola indefinidamente perde o vínculo com o território. É preciso, pois, estabelecer vínculos de parentesco e reciprocidade para manter o elo territorial. (Há famílias Guarani - mbyá dispersas no Pará, no Mato Grosso, no Maranhão, no Tocantis, na Bahia e em São Paulo, que romperam com o sistema de reciprocidade Guarani, misturando-se com outros grupos étnicos. A retomada de alguns 
contatos e de algumas relações entre esses Guaranis com os do Sul e do Sudeste do continente é ainda incipiente ou prematura para se prever a agregação dessas outras partes ao território tradicionalmente usado) (LADEIRA, 2008, p. 193).

Há outros estudos como, a exemplo da tese de Camila Sales Faria (2008), que apontam o processo de fragmentação, desintegração e retomada do território Guarani como decorrente de duas lógicas de apropriação do espaço: uma capitalista e outra indígena, como assinalado anteriormente. A natureza, para a lógica capitalista, assume um caráter de recurso natural, já na vivência indígena a natureza é vista como um sujeito, e o homem como uma extensão dela.

Para quem deseja entender melhor a questão Guarani na cidade de São Paulo, é apresentado nos trabalhos de Faria (2008; 2016) análises significativas e relevantes sobre os contextos jurídicos de muitas Terras. Há o foco na análise da questão indígena a partir do ponto de vista da geografia urbana e das contradições inerentes às lógicas de ocupação do espaço, especificamente das tekoá pyau e tekoá Ytu, no bairro do Jaraguá, em São Paulo.

No caso da comunidade Tenondé Porã, a fragmentação do território se deu por causa da não demarcação da área destinada à sobrevivência, a extensão territorial necessária para o desenvolvimento do modo de vida tradicional Guarani, baseada na agricultura e nas suas relações derivadas. A retomada dos territórios acontece com a expansão das aldeias pelo território reivindicado pela comunidade. Segundo uma liderança Guarani, da comunidade Tenondé Porã (Adriano, 2016, entrevista):

Aproximadamente dois anos, com a ida do relatório para a mesa do ministro da justiça, na época José Eduardo Cardoso, o pessoal já começou a ocupar, a se espalhar, a fazer a retomada, aqui já são 6 aldeias, uma no Marsilac, duas em São Bernardo do Campo e mais uma aqui atrás do Bairro da Barragem, totalizando seis aldeias contando com krukutu e Tenondé Porã. Isso já ocorre há dois anos. 
Essa fala de Adriano (2016, entrevista) é bem representativa do processo classificado como retomada dos territórios. Nesse momento, tem-se a ocupação efetiva de parte desse território que até então não se tinha, não porque ele não faz parte, mas porque as políticas de proteção e reconhecimento das Terras indígenas passam a ser mais ineficientes, ou mesmo, questionadas, como se abordou no caso da PEC 215, que força essas comunidades a expandir a ocupação efetiva dos territórios de pesca, coleta e plantio, como forma de assegurar sua demarcação jurídicos.

\subsection{A Caça, pesca e Agricultura na Tekoá Tenondé Porã}

Figura 17: Foto da Roça na Tekoá Barragem em 1980

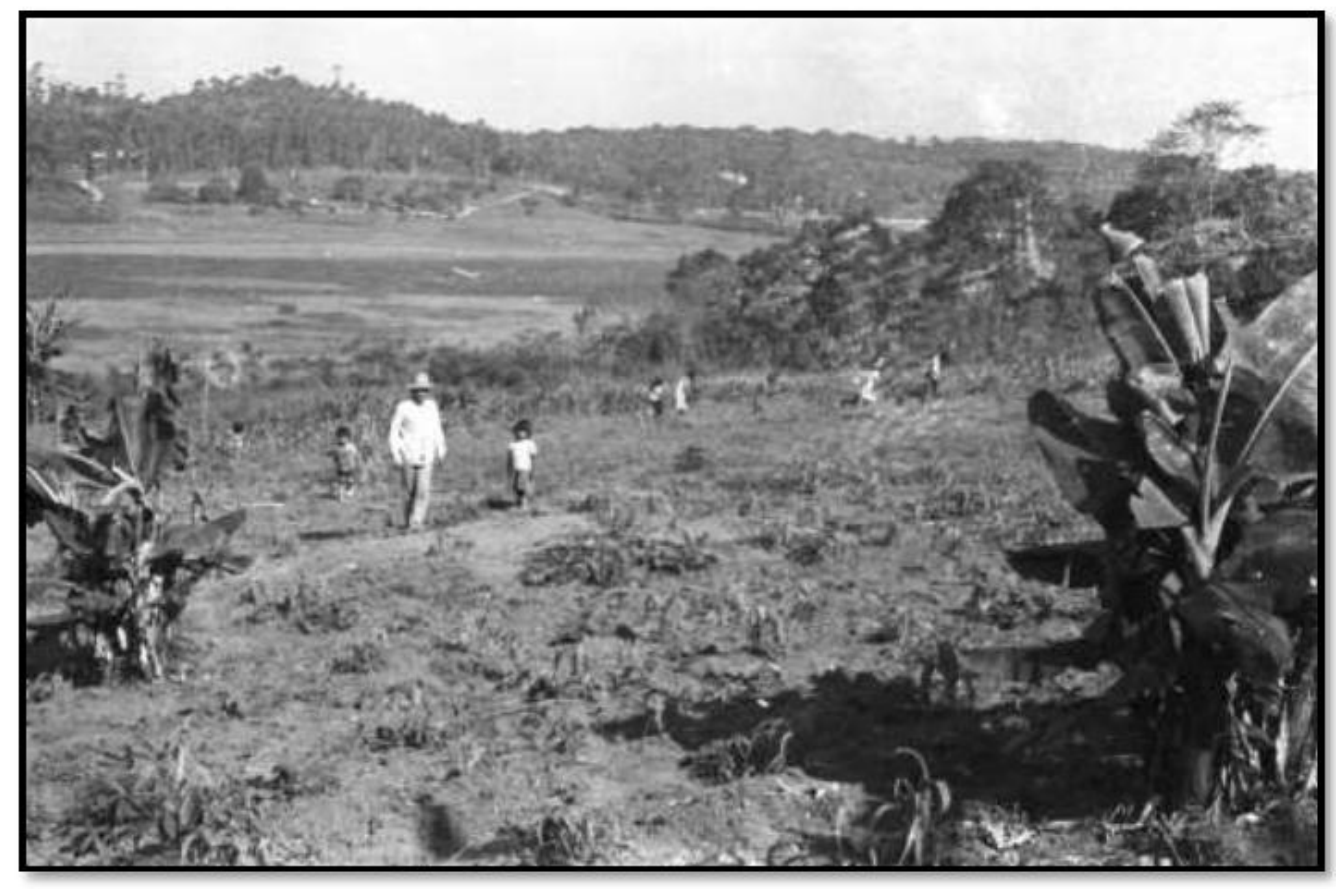

Fonte: Ladeira [arquivo CTI] apud Faria, 2016.

Figura 18 - Foto da Roça na Tekoá Barragem em 1988 


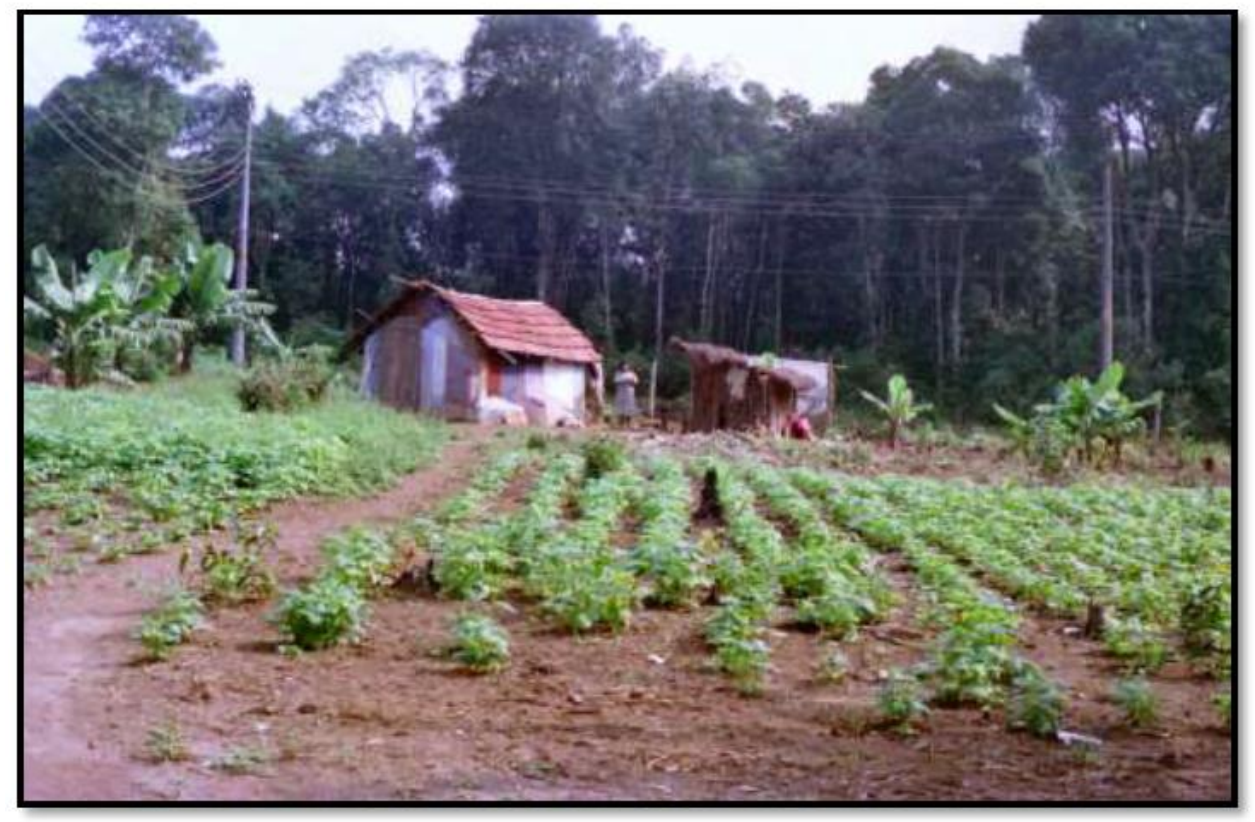

Fonte: Ladeira [arquivo CTI] apud Faria, 2016.

Figura 19: Foto do plantio de milho tradicional (avaxi) na aldeia Tenondé Porã em 2015

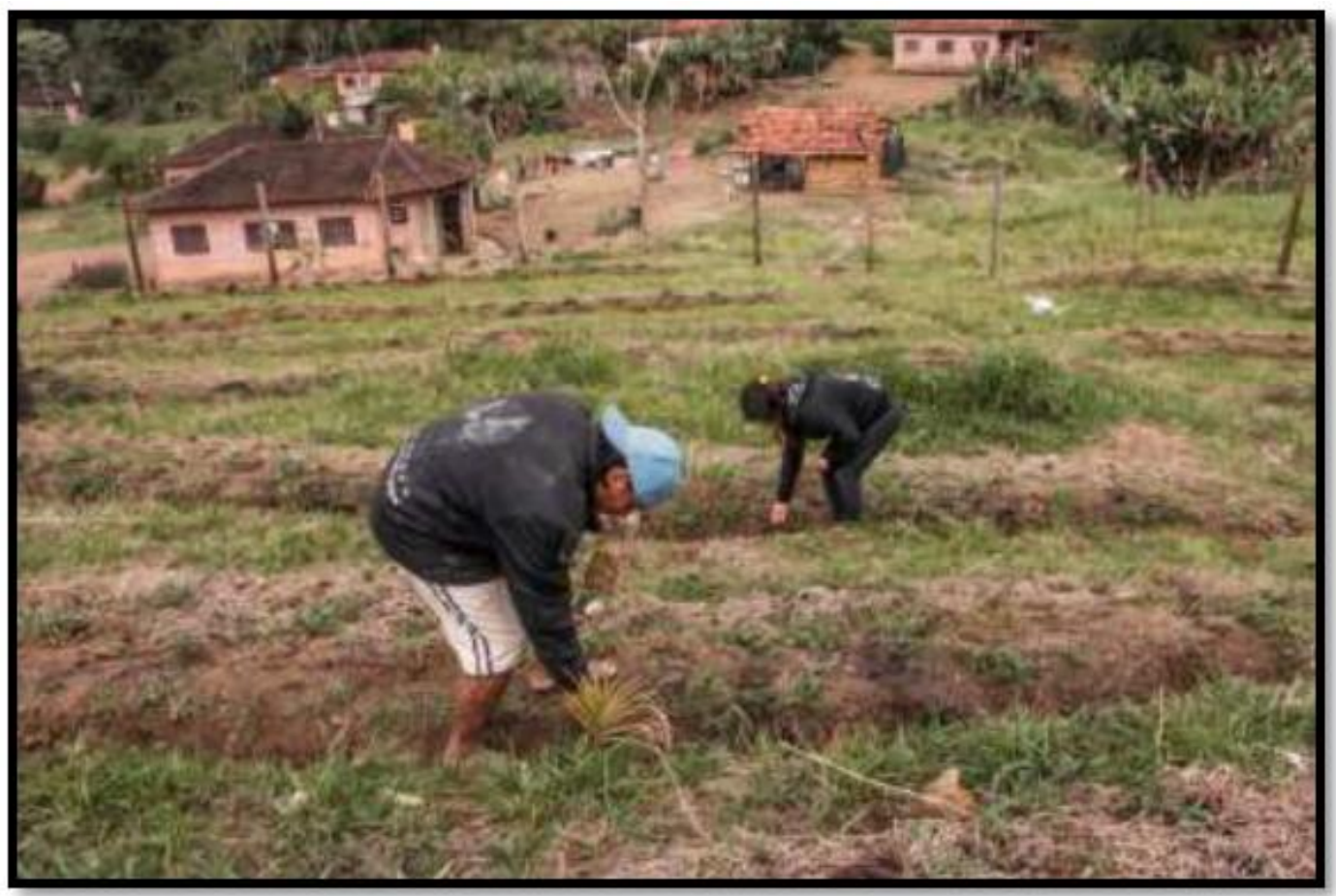

Fonte: Ladeira [arquivo CTI] apud Faria, 2016. 
Figura 20: Alimentos tradicionais Guarani.

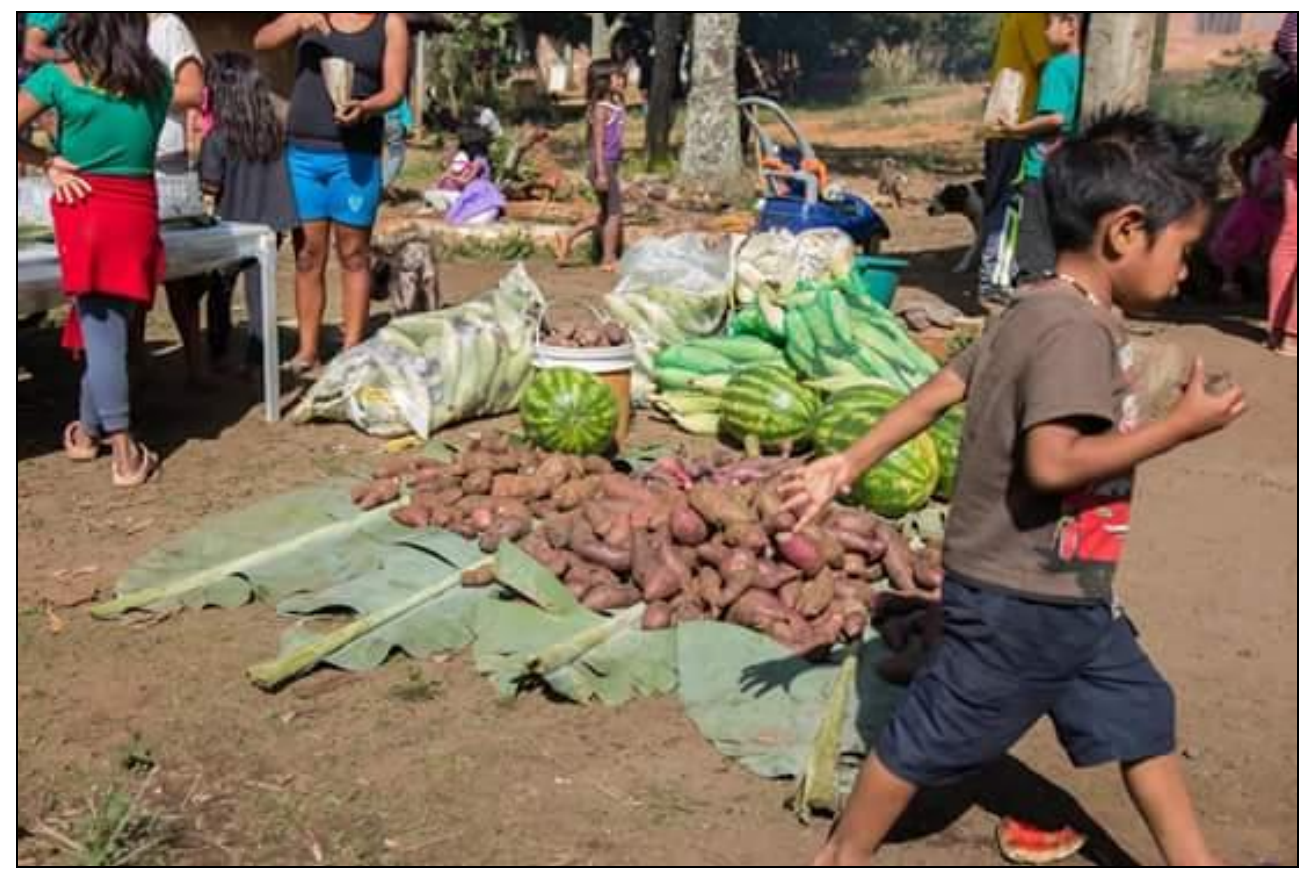

Fonte: facebook/cecitenondé (2017).

Como é possível observar nas imagens, o território ocupado hoje pelos Guarani da Serra do Mar tem registros que remetem a tempos anteriores, evidenciando a presença desses povos nesta área e o cultivo de alimentos tradicionais.

A agricultura é a base da existência Guarani, pois não está relacionada somente com a alimentação, mas com as práticas espirituais. A agricultura Guarani é a materialização dos elementos espirituais que regem o intercâmbio entre a comunidade e seu território. Segundo Faria (2016, p. 237):

A agricultura é uma prática que fundamenta a existência (física e espiritual) do Guarani, que expressa seu modo de ser/ viver (nhadereko). Sua prática não envolve somente a quantificação daquilo que foi plantado e colhido. Mas abrange outras relações materiais e imateriais, como as sociais, as simbólicas e as ritualísticas. As espécies plantadas (tradicionais ou não) têm a finalidade da dieta alimentar e do uso medicinal, principalmente. 
A agricultura e os rituais estão relacionados com dois tempos que equivalem a duas estações: ara pyau, que se refere ao tempo de calor (primaveraverão) e ara yma o tempo de frio (outono-inverno).

A agricultura é uma atividade estrutural da vida em comunidade para os Guarani, pois a possibilidade de seu desenvolvimento permite uma organização interna diferenciada, reciprocidade entre as famílias e aldeias, intercâmbios de sementes e espécies, experimentos diversos e manifestações ritualísticas.

No estudo realizado pela FUNAI (2012) observou-se que na TI Tenondé Porã e na Krukutu só é possível cultivar alguns tipos de alimentos que são importantes para manter a tradição Guarani. No entanto, não é possível desenvolver as atividades produtivas que permitam a manutenção integral das comunidades devido justamente à falta território.

As poucas lavouras que existem têm um papel fundamental, pois preservam tipos variados de sementes que, devido à lógica de produção de alimentos em grande escala que tem como consequência a predominância de uma única variedade de semente, estão ameaçadas. Na lógica de produção de alimentos Guarani a variedade é grande e não se limita a um único tipo de espécie. Os Guarani não vivem da agricultura, mas também não vivem sem ela.

As atividades produtivas tradicionalmente realizadas pelos Guarani na TI Tenondé Porã são a agricultura de coivara, a caça, a pesca, a coleta de frutos, larvas e espécies comestíveis, e, desde muito tempo, a confecção de artesanato para a comercialização, através da coleta de matéria-prima nas matas. A realização das lavouras tem conexão direta com o calendário ritual praticado pelos Guarani, sendo o milho o cultivar com maior valor cosmológico. Os Guarani da TI Tenondé Porã conservam ainda, a despeito do confinamento territorial ao qual estão submetidos, uma série de variedades próprias ("crioulas") de milho, batata-doce, feijão, mandioca, amendoim e cana-deaçúcar. O calendário produtivo dessas espécies regula e é regulado por duas grandes estações: os tempos novos (Ara Pyau), que coincidem com a primavera e o verão, e os tempos antigos (Ara Ymã), que coincidem com outono e inverno. Até a década de 1960, era possível aos Guarani da TI Tenondé Porã realizar o sistema de plantio de coivara, no qual se realiza a 
rotatividade das Terras agricultáveis a partir do corte e queima, e do pousio prolongado das áreas de roça. Atualmente, é possível plantar apenas nas áreas regularizadas Krukutu e Barragem, de modo que a lavoura garante apenas a manutenção de seus cultivares tradicionais, sendo pouco relevante do ponto de vista da subsistência (FUNAI, 2012).

Segundo a Guarani Djirá (2014) ${ }^{49}$ moradora da aldeia Tenondé Porã, algumas indígenas são guardiões de espécies vegetais, impedindo que elas desapareçam.

\begin{abstract}
A gente planta as nossas sementes tradicionais só para não perdê-las. Sou responsável por um tipo de batata bem roxinha por dentro, muito deliciosa. A maioria das aldeias já não tem, então eu planto, depois replanto, esperando a ampliação da Terra, quando poderemos plantar dentro do princípio Guarani.
\end{abstract}

Os rituais Guarani estão conectados à produção de determinados alimentos e de acordo com as estações do ano, como foi salientado. Isso só é possível ocorrer se houver, justamente, essa prática de manutenção da variedade de alimentos. No entanto, a partir do momento que se tenta incorporar esses grupos à lógica de sobrevivência da sociedade moderna com políticas de assistencialismo, como bolsa-família ${ }^{50}$, anula-se parte importante da possibilidade de manter a tradição Guarani viva. Essas medidas assistencialistas são extremamente necessárias, mas devem ser paliativas e devem estar fadadas ao desaparecimento a partir do momento que se tem a consolidação desses territórios que são indispensáveis para maior autonomia.

A impossibilidade de desenvolver o modo de ser tradicional Guarani traz grandes prejuízos para a comunidade, dentre eles pode-se destacar problemas de saúde, devido ao consumo de comidas industrializadas, problemas psicológicos, como depressão e dependência ao álcool. Portanto, realizar as atividades características da cultura evitaria uma série de prejuízos à comunidade.

\footnotetext{
${ }^{49}$ Retirado de reportagem do dia 4/04/2014 de www.brasildefato.com.br; acesso em 24/08/2017.

50 Programa do governo federal destino a famílias de baixa renda.
} 
Segundo Djirá (2014) ${ }^{51}$ : "Como não podemos plantar e colher, muitas pessoas entram em depressão, especialmente entre os mais velhos, e acabam tendo problemas com álcool”.

\section{FIGURA 21: Preparo de alimentos pelas crianças da comunidade}

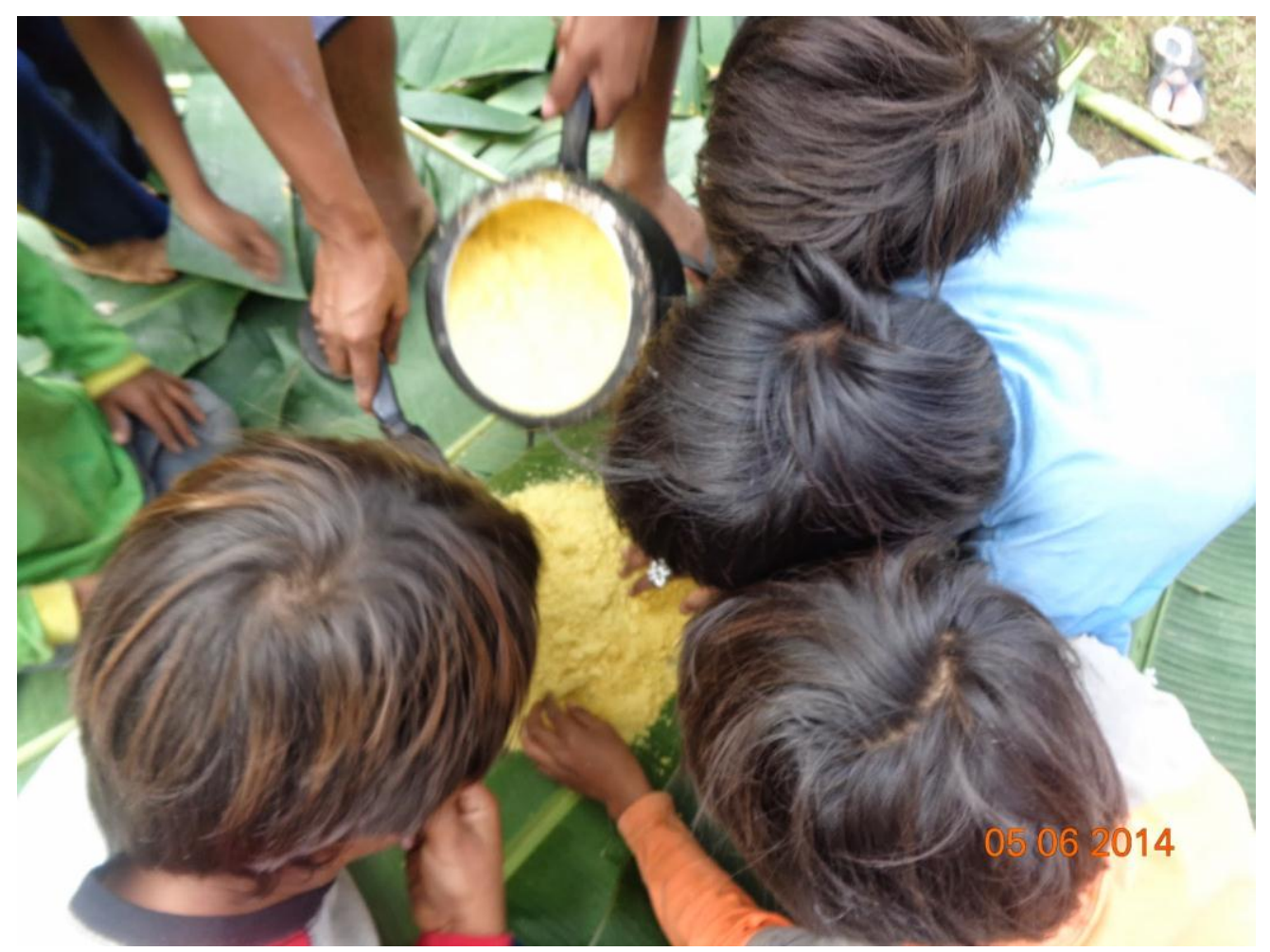

Foto: Veríssimo, Gabriel. ${ }^{52}$

${ }^{51}$ Retirado de reportagem do dia 4/04/2014 de www.brasildefato.com.br; acesso em 24/08/2017.

52 Retirado do site: www.cecitenondepora.blogspot.com.br; acesso: 25/08/2017 
FIGURA 22: CRIANÇAS APRENDEM A PLANTAR MILHO CRIOLO EM GUARANI

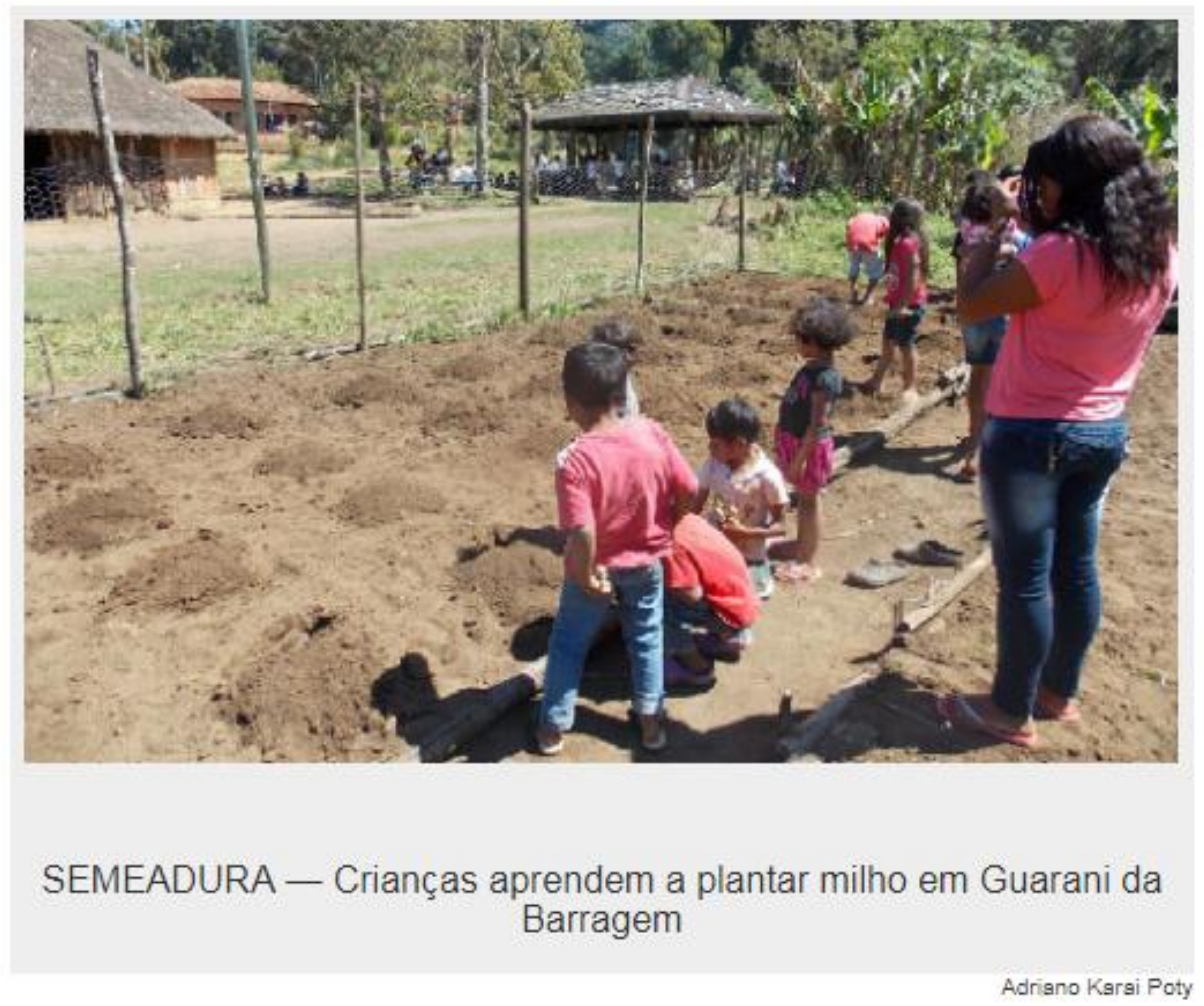

Fonte: Adriano Karai Poty ${ }^{53}$

A caça não é uma atividade constante entre os Guarani, pois envolve práticas simbólicas que só tem significado com a existência das espécies, portanto ela é uma atividade limitada pela disponibilidade das espécies para a caça. As regras para a caça são rigorosas e seu consumo respeita a seletividade e a sazonalidade. Em decorrência da fragmentação dos territórios indígenas, essa prática está seriamente comprometida.

${ }^{53}$ Retirado de www.camara.sp.gov.br; acesso em 25/08/2017. 


\section{CAPÍTULO III:}

\section{REPRESENTAÇÕES GUARANI: VISÕES DE MUNDO}

Este terceiro capítulo tem por objetivo apresentar o trabalho de campo e problematizar seus resultados à luz das discussões apresentadas até o momento e dos caminhos metodológicos apresentados inicialmente.

Foi realizada uma leitura individual e, ao mesmo tempo, conjunta das representações Guarani. Cada representação foi interpretada segundo as formas individuais de se pensar o território que, ao mesmo tempo, estão inseridas em um contexto social específico que imprime nessas imagens elementos que the dão conexão. 


\subsection{TRABALHOS DE CAMPO}

Os trabalhos de campo apresentados aqui totalizam oito visitas, que tiveram como principal foco discutir as questões relacionadas à cartografia e ao território Guarani.

O primeiro trabalho de campo realizado a partir do início oficial do mestrado ocorreu em outubro de 2014. Nesse encontro foi possível apresentar a pesquisa para Adriano, principal interlocutor Guarani da comunidade naquele momento. Foi apresentado o campo de estudo que envolvia a pesquisa: a geografia, a cartografia e os mapeamentos participativos como possibilidade de identificação e apresentação do território Guarani.

Essa primeira apresentação de ideias e trabalhos para Adriano ocorreu sem gravação, pois o intuito consistia em deixar Adriano tranquilo em relação ao que ele tinha a dizer a respeito da proposta de estudo na comunidade. Já havia observado, em outras oportunidades, que Adriano se sentia um pouco desconfortável pelo uso do gravador, isso levou a fazer a opção por não gravar nesse momento. Esse primeiro encontro teve duração de duas horas e todo o diálogo foi estabelecido somente com Adriano. Nesse momento, algumas futuras visitas foram definidas com Adriano de acordo com a disponibilidade dele e das demais pessoas que iriam participar posteriormente de oficinas e discussões.

O próximo campo ocorreu em janeiro de 2015 e nessa oportunidade observou-se com Adriano o plano de gestão territorial e ambiental da Terra indígena kampa do rio amônia dos Ashaninka ${ }^{54}$ e outros planos de gestão territorial e ambiental de outras comunidades. Todo o material foi levado em formato digital para que Adriano observasse e sugerisse algum o que poderia ser desenvolvido com a comunidade. O intuito era demonstrar o universo de possibilidades de estudo que poderia ser feito com a comunidade. Os materiais

\footnotetext{
${ }^{54}$ Plano de gestão territorial e ambiental da Terra indígena Kampa do Rio amônia - Rio Branco: Comissão Pró-Índio do Acre, 2007, 82 p.
} 
levados foram elaborados pelos próprios indígenas e continham muitas imagens, descrições de vegetação e animais, história das comunidades, tudo em língua indígena, pois o material também havia sido elaborado para o uso das próprias comunidades. O objetivo de levar esse tipo de material era apresentar possibilidades de se estudar cartografia e Geografia por meio do olhar indígena.

Quando apresentado a questão de entender o território a partir das representações que são feitas pelos Guarani, Adriano frisou também as problemáticas relacionadas à delimitação e ampliação da Terra da comunidade. Por isso o resumo do relatório de identificação e demarcação da FUNAI foi fundamental, pois segundo Adriano os antropólogos que realizaram em conjunto com a comunidade esse estudo tiveram bastante seriedade, inclusive são antropólogos que mantém relações com a comunidade até o momento por meio do Centro de Trabalho Indigenista (CTI).

O terceiro encontro ocorreu em abril de 2015 e foi levada a proposta da primeira atividade, a elaboração de mapas e representações diversas. Como o principal objetivo era entender a importância do território, de modo a considerar a percepção da comunidade, participando das entrevistas e oficinas quem manifestasse algum interesse sobre o assunto, a escolha de quem iria realizar os mapas ficou a cargo de Adriano. Friso essa questão da diferenciação porque alguns pesquisadores questionam o porquê de não ter estabelecido diálogo com o cacique. Entende-se totalmente a importância da fala do cacique, mas o contato com a fala do cacique se deu por meio dos relatórios da FUNAl e de outras pesquisas.

Antes de iniciar a atividade com os mapas foi apresentado para o grupo de cinco Guarani qual era o objetivo do projeto que estava sendo desenvolvido a respeito da comunidade. O tema da pesquisa, o território Guarani, foi problematizado e discutido com eles, colocando a seguinte questão "Como você representa seu território?". A proposta consistia na confecção de mapas realizados a partir da memória, dispondo somente de lápis de cor, giz (azul, amarelo, preto, 
rosa, laranja e verde $)^{55}$ e papel branco tamanho A4. Dos cinco indígenas que realizaram a atividade, somente com duas pessoas foi possível dialogar em outros oportunidades.

Para o universo dessa pesquisa, observou-se que para a atividade de produção de mapas feitos a mão, cinco pessoas da comunidade se interessaram e, por iniciativa própria, participaram da atividade. No entanto, para a produção do mapa georreferenciado, somente duas pessoas tiveram interesse, Adriano e Edmilson. Isso ocorre devido a pouca intimidade dos Guarani em trabalhar com computadores, não manifestando interesse em participar de oficinas por parte dos outros 3 Guarani que inicialmente haviam participado da atividade de desenhos de mapas. Essa questão está totalmente ligada à cultura Guarani, pois o afastamento que os indígenas mantêm de elementos de outras culturas, como o computador, é uma forma de resistência para a manutenção da cultura própria.

$O$ fato de ter inicialmente cinco pessoas por livre e espontânea vontade para as atividades de desenhos de mapas e, posteriormente somente 2 para 0 desenvolvimento de mapas georreferenciados, explica muito esse relativo afastamento da comunidade em relação a determinados conhecimentos externos.

A solicitação para fazer os mapas foi muito clara e objetiva, pois o pedido consistia em desenhar o que eles consideravam como território, como e o que eles iriam desenhar era livre, podendo cada um se expressar da forma que convinha, individualmente e coletivamente. A pergunta direcionada a eles foi objetiva, mas isso não quer dizer que a tarefa deles tenha sido fácil, visto que a concepção de mapa e território para os Guarani é algo complexo e dinâmico.

Posterior à realização dos desenhos, foi feita uma roda de conversa na qual cada um falava a escolha em desenhar tal elemento, esclarecendo para todos que estavam presentes, os 5 indígenas, o objetivo e o tema pertinente ao território que tinha abordado. Essa dinâmica em grupo foi extremamente enriquecedora. Foi a partir dela que observei detalhes nas representações que até então não havia observado, enquanto cada um apontava os porquês de cada

\footnotetext{
${ }^{55}$ As cores foram disponibilizadas pela pesquisadora, a escolha das cores no mapa foi feita pelos indígenas.
} 
elemento, pude observar uma lógica nos desenhos que era semelhante a todos, a presença da casa de reza e sua referência como central dentro do núcleo habitacional.

Para os Guarani ficou aquela interrogação sobre a importância dos desenhos que foram feitos e de como os desenhos responderiam as questões que haviam sido colocadas inicialmente a eles. Do material elaborado pelos indígenas, nenhum foi descartado, visto que sua leitura possibilitou elaborar uma abordagem conjunta.

Em setembro de 2015, no quarto encontro, foi feita uma oficina de cartografia com Adriano e Edmilson ${ }^{56}$, o tema central era discutir as definições de mapa dentro da sociedade contemporânea e sua influência e poder sobre a delimitação de territórios, bem como sua utilização recorrente nos planos de gestão ambiental e territorial em Terras indígenas. Levantar essas questões foi bastante pertinente, porque os próprios indígenas puderam olhar uma proposta de mapeamento com cuidado e entender a lógica de construção. Esse campo durou cerca de duas horas de duração.

Nesse quarto encontro também se explorou, junto com os Guarani, a possibilidade de visualização da área da comunidade por meio do Google Earth, um universo, até então, totalmente desconhecido para Adriano e os demais Guarani. Essa experiência foi importante para que os indígenas visualizassem a quantidade de possibilidades que existe quando se fala de mapas e mapeamentos na comunidade.

Mesmo tendo um universo gigante de possibilidades de trabalho com a comunidade, a tarefa de produzir mapas por meio dos sistemas de informações geográficas pareceu, para os indígenas, um trabalho que necessitaria de mobilização da comunidade, algo que está previsto sua realização, porém, em longo prazo.

Nessa oportunidade, foi possível apresentar e problematizar a importância da escala cartográfica. Foram feitos diversos exercícios de cálculo de escala com

\footnotetext{
${ }^{56}$ Tupã é coordenador pedagógico da escola municipal CEC e Edmilson é integrante da comunidade.
} 
o uso de um mapa-múndi e de uma régua ${ }^{57}$. Observando o mapa, os indígenas escolheram alguns rios para serem observadas suas distâncias reais a partir da regra de três. Esse procedimento causou relativo espanto para eles, pois até então eles desconheciam a lógica dos mapas georreferenciados, constituindo-se este conhecimento uma forma de conhecer o mundo do outro.

Outros temas também foram explorados, como por exemplo os elementos que compõem um mapa que é utilizado recorrentemente por órgãos administrativos. Essa experiência causou estranhamento inicial aos Guarani e, ao mesmo tempo, encantamento posterior. Essa prática também possibilitou eles entenderem melhor o que havia sido apresentado inicialmente, sobre o que é cartografia e para que ela serve, afinal.

Em janeiro de 2016 foi realizado o quinto encontro, com o intuito de desenvolver um mapa georreferenciado, denominado aqui de fragmento do território Guarani da Serra do Mar. A construção desse mapa foi acompanhada do estudo com Adriano e Guarani do sistema de informação geográfico (SIG), explorando a base de dados fornecida pelo IBAMA sobre as Terras indígenas no Brasil. Pela ferramenta information foi possível verificar a situação jurídica de grande parte das Terras indígenas no Brasil e a visualização, por parte dos Guarani, das diversas possibilidades de manuseio desses dados. Todos os encontros foram realizados na escola municipal da aldeia.

A partir da visualização das informações por meio do SIG foi possível visualizar o formato da demarcação de diversas Terras. Algo que causou estranhamento aos indígenas foi a existência de Terras indígenas que são exatamente quadradas. Segundo Adriano (2005) os territórios indígenas não são quadrados ou retângulos perfeitos, a lógica de demarcação envolve outros fatores, como a existência de elementos naturais, como formas geográficas particulares, que vão marcar a divisão, ou o limite entre o que está demarcado ou não. Portanto, para ele causa espanto que uma Terra indígena tenha limites tão perfeitos, como se alguém tivesse pensando o recorte da Terra da comunidade

\footnotetext{
${ }^{57}$ Material disponibilizado pela pesquisadora.
} 
sem ao menos conhecer a área, que provavelmente tem elementos naturais que demarcariam os limites da Terra.

A elaboração do mapa, do que se aponta como território indígena Guarani, ocorreu posteriormente ao estudo das ferramentas e possibilidades de manuseio do SIG. Após observar as informações que estavam vinculadas às Terras das comunidades, passou-se para efetivamente a construção do mapa. Todos os procedimentos no computador foram realizados por Adriano e Guarani, pois o objetivo era que eles realizassem todas as etapas de construção sozinhos, somente com alguma orientação solicitada.

O objetivo em desenvolver esse mapa foi permitir a visualização zenital do território Guarani, bem como uma forma de levar à comunidade uma experiência, ainda que efêmera, daquilo que se acredita ser uma cartografia participativa. Obviamente, essa cartografia desenvolvida é limitada, pois demandaria anos para realizar um mapeamento completo dos aspectos naturais para o desenvolvimento de estudos mais profundos sobre as possibilidades de gestão. Portanto, limitou-se nesse momento inicial a construção de um mapa com a visualização zenital daquilo que já havia sido discutido a respeito dos limites desse território Guarani, como um mapa que se apresenta como "polo consistente de um discurso construído coletivamente" (FONSECA; 2016, p. 68), tanto verbal como visual, sobre o fragmento do território Guarani da Serra do Mar. Este mapa se tornou a base cartográfica para construção dos demais mapas apresentados nessa pesquisa. 
Figura 23: MAPA INICIAL ELABORADO COM ADRIANO E EDMILSON

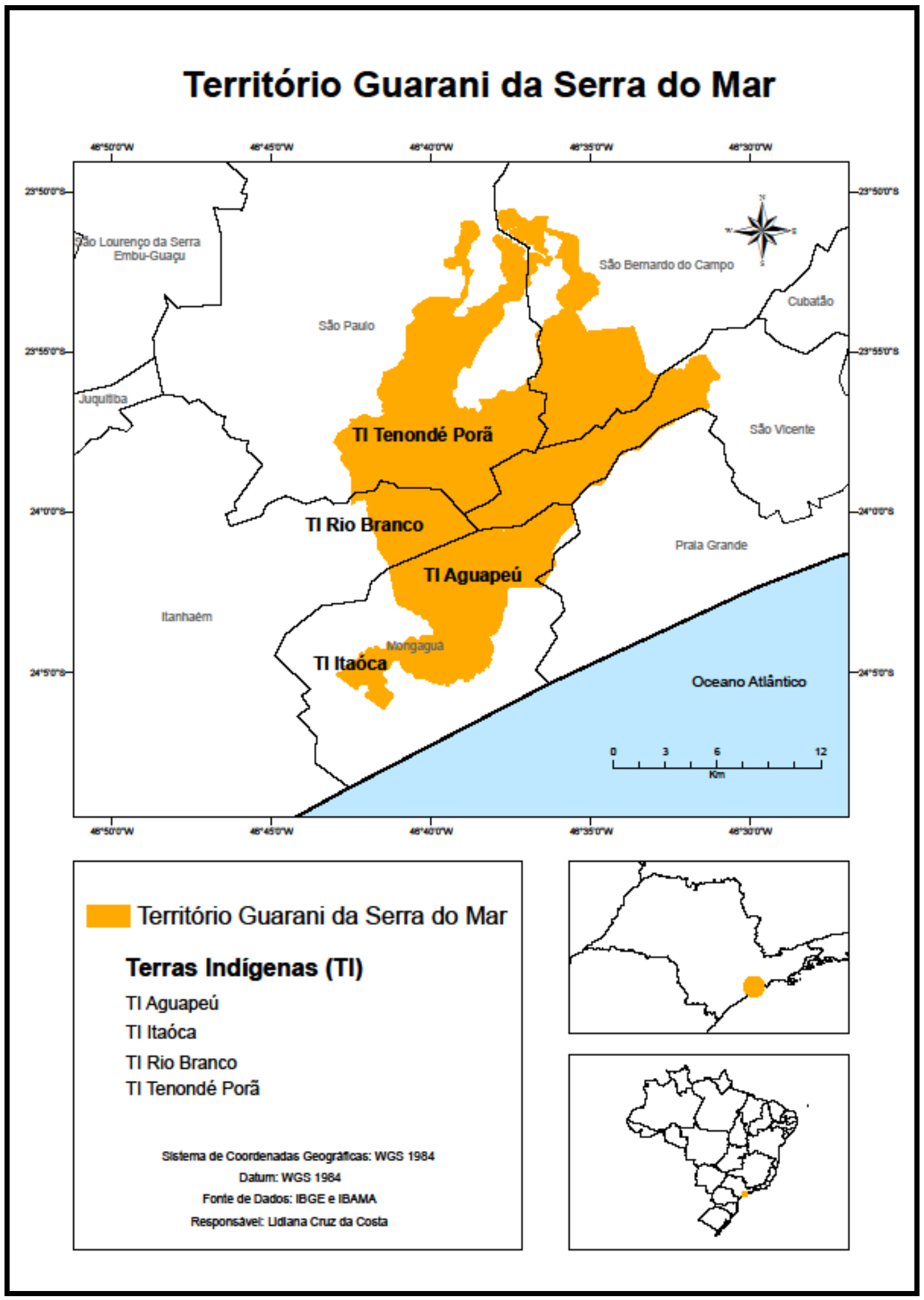

Fonte: COSTA; ADRIANO; GUARANI, 2015 
Os trabalhos de campo são uma forma de adentrar o universo da comunidade e aos poucos ganhar a confiança. Assim, a participação nos espaços de trocas e convívio é fundamental e, mesmo que a finalidade de um campo seja somente a presença da pessoa na comunidade, é imprescindível para aprofundar os laços, o que possibilita maior troca de conhecimentos.

A sexta visita ocorreu em abril de 2016 e teve como intuito observar a comunidade e seu entorno, estabelecer contato com os bairros que circundam a comunidade. O propósito nesse momento foi realizar uma caminhada dentro e fora da comunidade, pois a proximidade da aldeia com os bairros causa problemas diversos, dentre eles o número crescente de Guarani que estão se envolvendo com algum tipo de droga, como o álcool, problema que se estende desde a década de 80 , segundo relatos. A proximidade com os bairros pode ocasionar maior pressão sobre a comunidade em decorrência do crescente loteamento irregular de Terras no entorno da comunidade.

Nesse momento, também foi possível observar a proximidade dos bairros com a represa Billings, o que gera grande fluxo de esgoto clandestino no rio, afetando diretamente parte das águas que servem à comunidade. Esse momento foi fundamental, pois já havia feito diversas revisões bibliográficas e análises das representações, e ali observações foram feitas com o olhar direcionado para os aspectos que julgava dialogar com o material.

Adriano nesse momento realizou um pedido com relação à minha presença na comunidade, que segundo ele deveria ocorrer de 15 em 15 dias, pois assim a comunidade também poderia me conhecer melhor e o compartilhamento de informação seria mais fácil. Interessante observar que se há um relativo afastamento dos Guarani em relação aos não índios, também há um interesse quanto a presença do outro para trocas, pois isso converge com o que observou Eduardo Viveiros de Castro. Segundo Castro (2008), a relação que a comunidade estabelece com o outro é profundamente diferente. Para os povos indígenas a presença do outro na comunidade não deve estar atrelada somente aos objetos materiais que intermediam essa relação, que nesse caso são os mapas e as 
representações, mas para eles o mais interessante e fundamental são as relações que se constroem, entre comunidade e pesquisador.

Se fosse possível transferir essa situação para sociedade contemporânea, poderia dizer que o mais importante não é aquele livro que você deposita no final de uma trajetória de três anos, mas as relações que foram construídas, o processo, e que provocaram diversas transformações na personalidade de uma pessoa. Para a comunidade, esse papel com tinta não tem a mesma importância que para a sociedade contemporânea, para eles a relação que se construiu é muito mais significativa, por isso, os mapas são só uma ponte que possibilita um intercâmbio cultural.

As casas, os rios, a escola municipal (CECl), o posto de saúde, a escola estadual e a casa de reza são objetos que compõem o núcleo habitacional da comunidade e fazem parte de uma lógica de apropriação material e simbólica do território que permite entender muito da forma de organização espacial da comunidade, quer dizer, das espacialidades. Portanto, observar esses elementos e entendê-los possibilita muito sobre compreender o histórico de ocupação da Guarani naquela região. 
FIGURA 24: PLACA DE IDENTIFICAÇÃO DA APA CAPIVARI MONOS

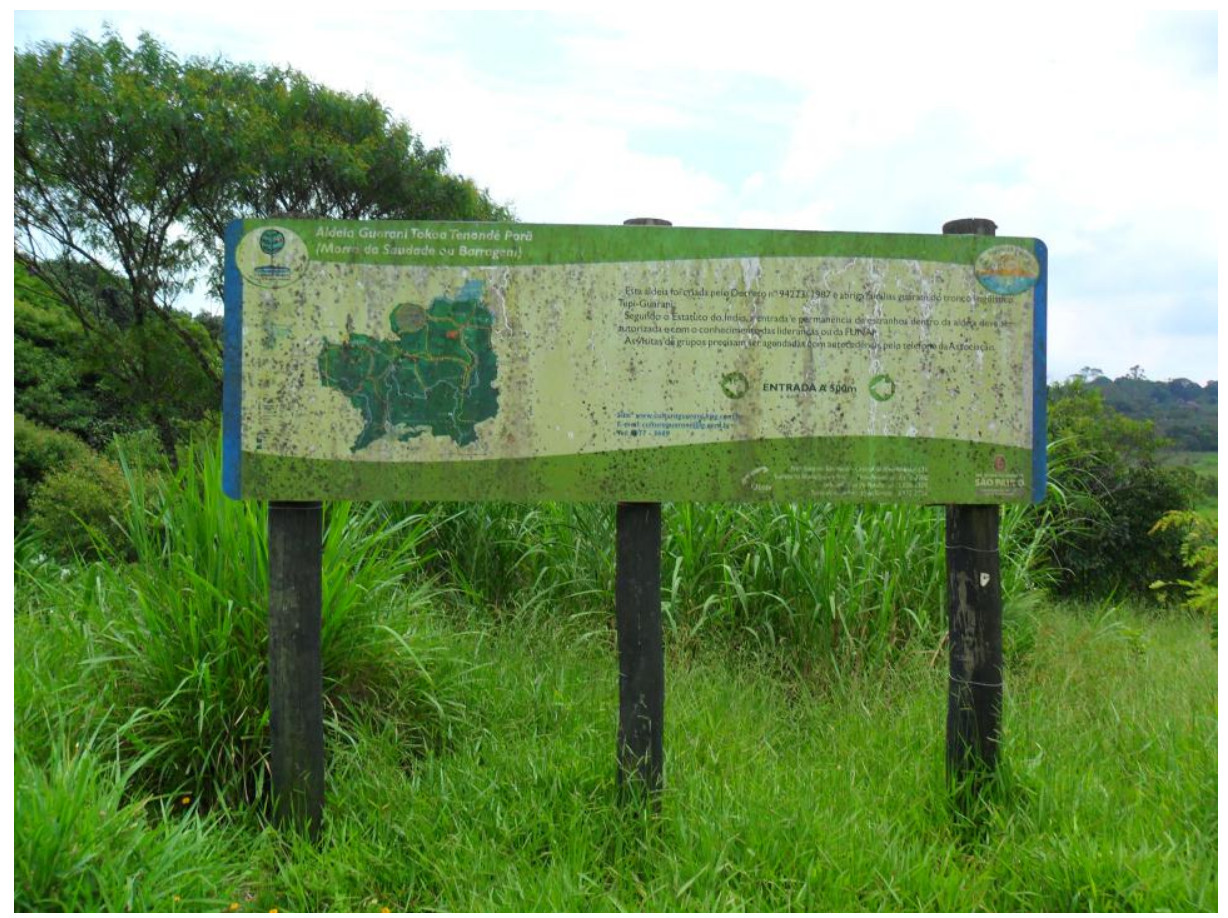

Fonte: Costa, 2013

FIGURA 25: CASA CONSTRUÍDA NO PROJETO HABITACIONAL

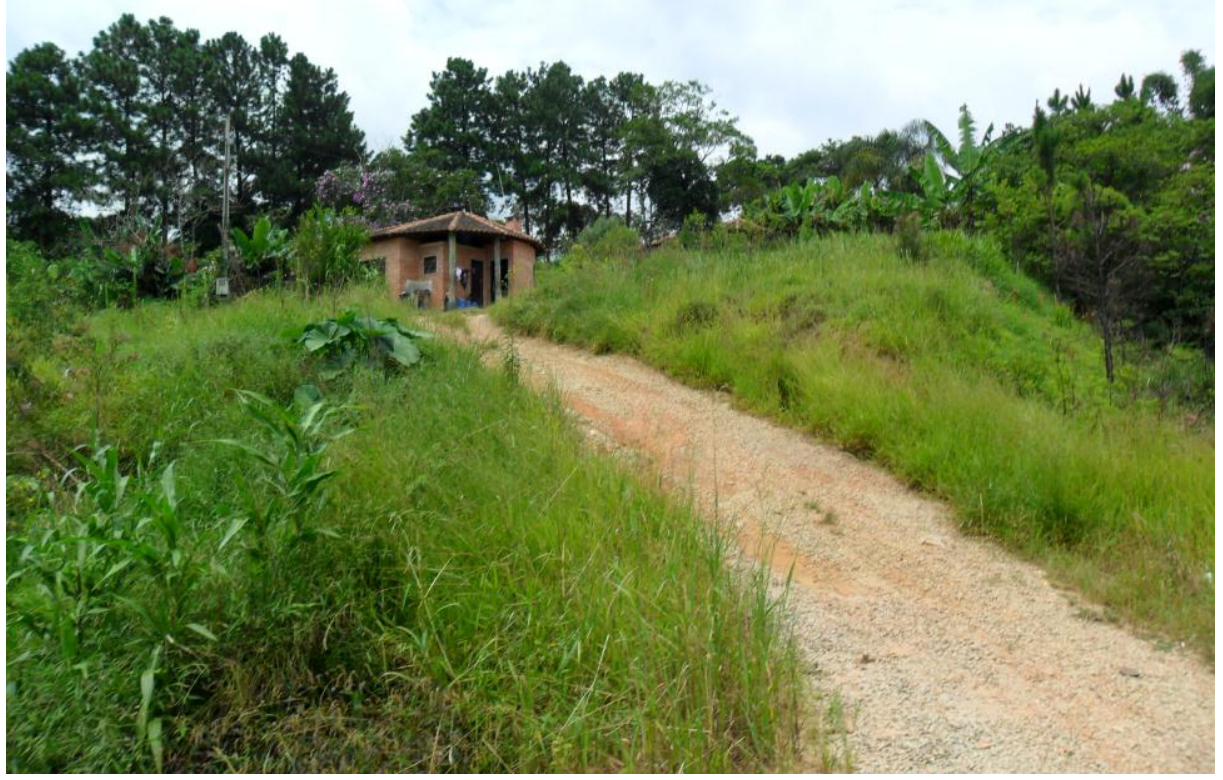


Fonte: Costa, $2013^{58}$.

A sétima visita ocorreu em setembro de 2016 e teve como duração o período da manhã e da tarde na comunidade. Esse campo se deu devido ao convite realizado por Adriano para participar de uma assembleia que ocorre anualmente da "Comissão Guarani Yvy Rupa", que tem seu escritório móvel instalado na aldeia Tekoá Tenondé Porã. Yvy Rupa é uma expressão utilizada pelos Guarani para fazer referência ao território de ocupação tradicional Guarani. Essa organização "vem se consolidando como importante protagonista político do movimento indígena nacional, realizando suas assembleias anuais e garantindo, pouco a pouco, vitórias importantes na longa luta pelo reconhecimento dos direitos territoriais de nosso povo". 59

A forma de articulação da comissão se baseia nos modos próprios de organização Guarani, compondo essa articulação lideranças que são mediadores, tradutores e assessores que representam os interesses coletivos da comunidade. Nesse encontro estiveram presentes lideranças indígenas do Fórum de Comunidades Tradicionais (FCT) de Angra dos Reis, Paraty e Ubatuba. Além de demais lideranças de diversas outras comunidades do Brasil.

O principal foco do encontro era discutir a questão da Terra, da saúde e educação diferenciada, sua duração total foi de três dias. Segundo Alexandro Kuray Mirim (2016), o encontro permitiu conhecer outras realidades dos povos Guarani, pois "Estão todos precisando de maior força. Os problemas de Terra são muito fortes e envolvem a morte de muitos indígenas e a saúde precária das populações".

Esse encontro permitiu observar as formas de articulação políticas mantidas entre as diferentes comunidades, que não se limitam a articulações locais, participando de encontros lideranças de diferentes partes do Brasil, Paraguai, Uruguai e Argentina. As formas de resistência, lutas e adaptações entre os Guarani ocorrem a partir também da construção coletiva de um discurso voltado

\footnotetext{
${ }^{58}$ Casas construidas pelo Programa de Moradia Indígena CDHU do governo e São Paulo.

${ }^{59}$ Retirado do site: www.yvyrupa.com.br.
} 
para a recuperação de territórios. Esse discurso coletivo, essas redes de apoio e cooperação entre os Guarani é também mantida por meio dessas assembleias e encontros. Segundo Marcos Adriano (2016), coordenador geral da comissão:

Estamos preocupados com projetos de lei $[\mathrm{PL}]$ e de emeda à Constituição [PEC] que estão no Congresso Nacional, como a PEC 215 [que transfere do Executivo para o Legislativo a decisão final sobre a demarcação de Terras indígenas]. Estamos discutindo também sobre território, educação, e demarcação de Terras indígenas Guarani na faixa litorânea no Sul e no Sudeste.

\section{FIGURA 26: ASSEMBLÉIA DA COMISSÃO YVY RUPA}

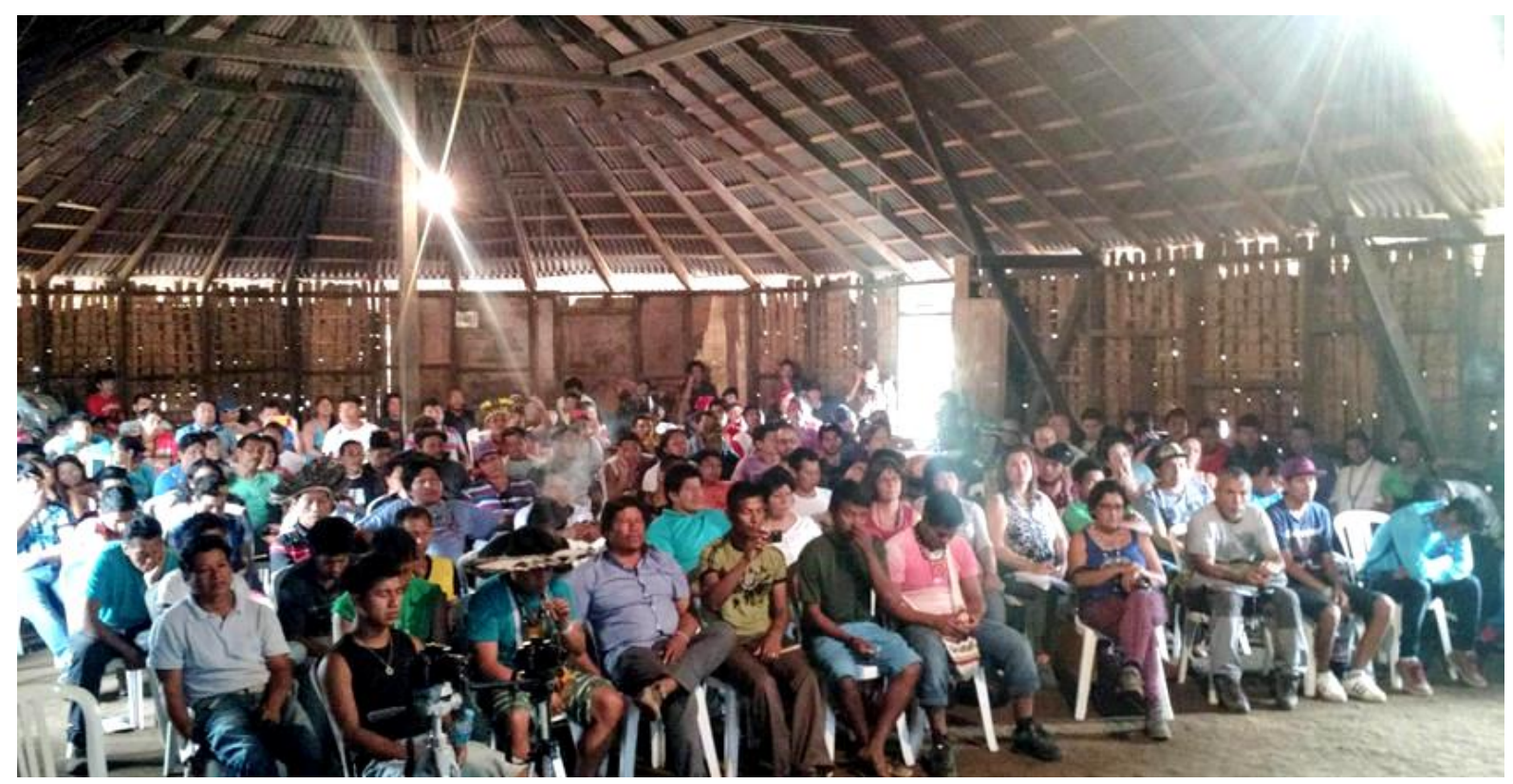

Fonte: Mirim, 2016.

O convite realizado por Adriano para participar da assembleia foi muito simbólico, pois demonstrou que, em alguma medida, certa afinidade foi criada entre interlocutores, aqui se coloca o pesquisador como interlocutor, também como produtor de uma dada representação do território em questão. Tal 
representação foi construída a partir do convívio e da troca com os Guarani nos seus espaços de luta e resistência, como nas assembleias da comissão yvy rupa que ocorrem justamente para discutir, em nível nacional, as estratégias de recuperação dos territórios perdidos. Prova disso é que o conceito que se identificou, por meio da bibliografia, como central para o entendimento do que seria esse território Guarani, yvy rupa, foi fundamental para compreender a dimensão territorial Guarani, constituída por meio das discussões e representações postas no encontro da comissão yvy rupa.

A oitava visita teve como intuito apresentar o conjunto de mapas elaborados a partir dos resultados obtidos na pesquisa. Constatou-se que havia uma relação direta entre fala e representação Guarani, pois os recortes geográficos trabalhados são vários (Terra, fragmento, território e aldeia), dificilmente são apreendidos somente com um tipo de linguagem, apelando-se para a visual, como forma de expressão dessas escalas territoriais Guarani que são complexas.

Por fim, pode-se concluir que, por meio dos trabalhos de campo, foi possível compreender melhor o meu olhar sobre aquela realidade, um olhar proposto a encontrar indícios de uma cartografia.

\subsection{AS REPRESENTAÇÕES COMO EXPRESSÃO CULTURAL DO COLETIVO}

Clastres (2010) observou que os povos Guarani não se apropriaram tão rapidamente da escrita como forma de representação do mundo. Eles têm na oralidade a forma principal de transmissão de conhecimento.

O modo de pensar, o mundo dos grupos está intimamente ligado com a forma que ele é representado, bem como com os instrumentos de comunicação, visual e oral. Desse modo, constatou-se que é por meio dessa linguagem que conceitos geográficos, como território, Terra, distância e fronteira podem ser compreendidos como parte de uma visão espacial sobre o mundo que é singular e que está ligada a padrões cognitivos diversos. O antropólogo Jack Goody (1977, apud LEITE, 1998, p. 53) disse: 
[...] chama nossa atenção e insiste sobre as especificidades dos instrumentos de comunicação enquanto esses são os determinantes de "estilos cognitivos", de modos singulares de pensar o mundo, de expressá-lo e de, nele, viver.

William Balée (1993) já havia assinalado que uma das diferenças cruciais entre o conhecimento tradicional e o pensamento científico moderno é a diferença de linguagem. A ciência prioriza a escrita, as comunidades indígenas utilizam a oralidade, isso explica porque, na classificação botânica de plantas da Amazônia, a ciência identifica 30.000 espécies, enquanto que os grupos indígenas dificilmente utilizam mais de mil nomes diferentes para a mesma flora.

Segundo Ladeira (2008, p. 28) fazendo uma comparação entre os modos de transmissão de conhecimento de nossa sociedade e a dos Guarani percebe-se que o próprio ato de escrever sobre essa cultura é demandado um significativo esforço de contextualização, pois as palavras só tem sentido, assim como as representações visuais, nos seus contextos de criação e reprodução.

[...] a sociedade Guarani, assim como outras sociedades ágrafas, tem na palavra oral a sua força e forma criativa de expressão e de transmissão, o que, por seu lado, exige um pensamento organizado e traduzível em expressões e conceitos definidos, palavras que fluem com seu próprio significado:

Guillermo Bonfin Batalla (1987) trabalhou com as identidades dos povos da América e fez algumas observações pertinentes que podem ser entendidas aos grupos Guarani. Para ele, o indígena não se define por uma série de características externas: eles têm uma série de características individuais que permitem entendê-los dentro de uma coletividade:

O índio não se define por uma série de características externas que o faz diferente perante aos olhos de estranhos (a vestimenta, a língua, as maneiras, etc.); se define por pertencer a uma coletividade organizada (um grupo, uma sociedade, um povo) que 
possui uma herança cultural própria que está sendo forjada e transformada historicamente, por gerações sucessivas; em relação a essa cultura específica, se sabe e se sente maya, purépeche, seri ou huasteco (BATALLA, 1987, p. 48, tradução nossa).

O contexto de transmissão dos conhecimentos, expressos em vários gêneros de oralidade, esclarece a transformação das "representações individuais" em "representações coletivo-público-cultural", construídas dentro da própria comunidade (GALLOIS, 2002). As narrativas individuais se tornam, então, representações coletivas.

As representações individuais são coletivas na medida em que o indivíduo pertence a uma coletividade, que por sua vez, tem características próprias. No caso das sociedades indígenas, esse aspecto se torna ainda mais evidente e significativo quando comparado às representações feitas do espaço pela sociedade contemporânea e a dos grupos indígenas.

O intuito não é comparar as representações das comunidades indígenas com as da sociedade contemporânea, mas pontuar que há uma significativa diferença que deve ser problematizada e mais aprofundada em outras pesquisas, pois como será possível observar mais adiante, as representações indígenas são singulares e refletem a forma de pensar e ocupar o território pelos Guarani. Nuances e traços que são feitos no papel e que guardam segredos da cultura que, só por meio do estudo aprofundado dos contextos, é possível compreender como expressão de um modo de ocupação espacial.

Batalla (1987) observou que nas culturas indígenas, a natureza não é inimiga do homem, ela faz parte de uma ordem cósmica a qual sempre se aspira uma integração permanente, só alcançada a partir de uma relação de respeito. Segundo Descola (2000), na cosmologia indígena, a natureza, não é um objeto alheio ao homem, ela assume uma posição de sujeito nas relações sociais. Isso explica porque nas representações Guarani há a presença de animais, fato que ratifica a ideia na qual os animais e plantas são seres que ocupam uma posição central no imaginário dos povos Guarani. Fato que será observado nas representações que serão apresentadas. 


\subsection{TERRITÓRIOS GUARANI EM REDES: ARTICULAÇÕES POSSÍVEIS}

A comunidade Tekoá Tenondé Porã teve e ainda tem, relativamente, influência sobre as demais aldeias da região, pois sua localização é extremamente fundamental para as diversas comunidades que circulam entre o litoral e a cidade de São Paulo, sempre em busca de material e também de articulações políticas, trocas culturais e encontros regionais, estaduais, nacionais e internacionais.

O conceito de território ganha movimentação para além dos limites da aldeia, ou da Terra indígena demarcada, pois as trocas entre as comunidades não se realizam somente no núcleo habitacional, mas engloba outras comunidades. Desse modo, acredita-se que o território Guarani é organizado em redes, como já havia observado LADEIRA (2008), e possui extrema importância, já que este modelo de organização espacial exerce papel central na circulação dos diversos grupos o que possibilita conhecer diferentes espaços e realidades por meio das trocas.

A ideia de nó geográfico expressa bem como as espacialidades Guarani são construídas. Alguns objetos são como nós, eles estabelecem conexões no espaço, caracterizando-o como um território ligado a partir de redes. Ladeira (2008, p. 87) coloca que:

Os grupos indígenas - sobretudo os do Centro - oeste, Sul, Sudeste e Nordeste -, cujas Terras insuficientes os levam a compartilhar territórios com outras sociedades, acabam se inserindo em uma rede maior de relações. Por seu lado, os índios Guarani mbyá, que se enquadram nesse contexto estabeleceram suas próprias redes a partir de sistemas de ações que envolvem seus tekoá (aldeias), superando distâncias geográficas e administrações oficiais.

No caso da Tenondé Porá, local que historicamente foi caminho de passagem entre os grupos do litoral e da região sul de São Paulo, essa ideia é 
bem representativa. A localização privilegiada da comunidade Tenondé Porã permite o acesso às matérias-primas necessárias para a produção de artesanatos e de outros produtos importantes para a manutenção das atividades culturais e a renda das famílias Guarani (ADRIANO, 2016).

No entanto, segundo Haesbaert (2002) o conceito de rede na Geografia expressa outro tipo de território, o do capital, ligado por meio das trocas de mercadorias, recursos e informação, diferente das redes de trocas dos Guarani que está intimamente ligado aos aspectos culturais. Portanto, o conceito de redes aqui foi encarado de uma outra forma, pois as discussões existentes na geografia não se aproximam da espacialidade construída pelos Guarani por meio das redes.

A parentela e a mobilidade espacial, que ligam as famílias nos diferentes pontos do território, é uma característica fundamental para sustentar a ideia de rede do território Guarani da Serra do Mar. Isso porque é por meio das aldeias permanentes e transitórias que as relações permeiam os diferentes territórios. Segundo um chefe de família Guarani (LADEIRA, 2008, p. 100):

[...] sempre, sempre foi assim: caminhando e encontrando as aldeias e os parentes, e parando, e trabalhando, e formando outra aldeia. E antigamente, é como hoje, existiam muitas aldeias, até muito mais, que a gente a andando e encontrando. $E$ tem aldeia que não existe mais, e agora tem outras. Mas, antes, tinha mais gente, mais aldeias e mais parentes nos caminhos.

Retomando a discussão do conceito na língua Guarani que expressa melhor essa ideia de território é Yvy Rupa, que reforça a ideia de redes, este deve ser entendido em uma escala mais ampla, pois faz referência ao território maior, constituído por todos os locais que possibilitariam o desenvolvimento do modo de ser tradicional, o nhadereko. De acordo com os estudos antropológicos desenvolvidos pela FUNAI (2012), Yvy Rupa é um termo muito polissêmico, porém pode ser entendido como território de ocupação.

O conceito utilizado na língua Guarani para designar seu território de ocupação, mais precisamente entre os Mbya falantes é Yvy 
Rupa. Esse termo, polissêmico, pode ser traduzido literalmente como "suporte (ou plataforma) terrestre", e abrange toda a extensão do território onde os Guarani estabelecem ou consideram possível estabelecer suas aldeias e assentamentos (Diário Oficial da União, 2012, p. 20).

Ainda segundo David Martins Guarani, da tekoá Jaraguá, esse conceito remete à ligação espiritual existente entre as diversas aldeias:

Para nós o Yvy rupa, o território Guarani, ele tem sentido quando existe uma ligação entre todos. Todos os Guarani estão ligados através da espiritualidade, através da reza, um reza pelo outro, e se comunica através da reza. [...] Porque para nós Guarani, não existe a divisão de fronteira, divisão de Estado, divisão de país. Isso foi um processo histórico da formação do território brasileiro, e também da formação do continente da América do Sul. Por isso que para os Guarani, o território é um só, que a gente chama de Yvy Rupa. ${ }^{60}$

Como colocado por David Martins Guarani, o território só tem sentido quando existe essa ligação entre as diversas comunidades, por isso se pensa 0 território Guarani estruturado a partir de redes, pois é por meio da espiritualidade e das rezas que os Guarani anulam a existência das fronteiras e das distâncias entre as comunidades, aprofundando os laços espirituais. Portanto, a Yvy Rupa é o território mais amplo, que abrange outros países, onde não deveriam existir fronteiras, na concepção Guarani, sendo a circulação uma característica imprescindível para a reprodução desses povos.

Nessa fala de David (2016) encontra-se a ligação entre os tópicos dessa pesquisa, que se traduz na problematização dos conceitos fundamentais para se entender o território Guarani, são eles: Terra, rede, distância e fronteira. Todos ganham novas definições quando se considera o território do ponto de vista Guarani. Conceitos que contribuem também para entender e pensar como experiências cartográficas podem contribuir para entender as espacialidade das

\footnotetext{
${ }^{60}$ Retirado do documentário "programa aldeias".
} 
comunidades e como elas são representadas, pois será a partir de suas representações que seu entendimento será melhor.

O conceito de território, dentro da Geografia, foi se consolidando e incorporando cada vez mais novas definições. Apresenta-se novamente aquela que melhor dialogou com os resultados, pois é aquela que define que o território é o produto das relações desiguais entre as forças, pois mesmo com a luta constante dos povos indígenas pelo reconhecimento da tradicionalidade de muitos territórios, os interesses que prevalecem ainda é o da minoria. Segundo Haesbaert (2002, p. 121):

Podemos, então, sintetizar, afirmando que o território é o produto de uma relação desigual de forças, envolvendo o domínio ou controle político -econômico do espaço e sua apropriação simbólica, ora conjugados e mutuamente reforçados, ora desconectados e contraditoriamente articulados.

Quanto ao conceito de distância, as diferentes etnias podem apresentar proximidade e distância que estão mais relacionadas às suas diferenças culturais e não necessariamente à distância quilométrica. Portanto, estar próximo ou distante de uma comunidade não se traduz por uma medida em quilômetros, mas por elementos ligados ao tronco linguístico, à religiosidade, a possibilidade de trocas e a parentela ${ }^{61}$ etc.

Essa característica já havia sido assinalada por Milton Santos (2004, p. 33) na observação que as distâncias físicas não necessariamente eliminam as distâncias sociais. No caso dos povos Guarani isso é válido porque o conceito de distância está mais relacionado a questões subjetivas do que objetivas, como foi salientado anteriormente.

[...] Mas a proximidade física não elimina o distanciamento social, nem tampouco facilita os contatos humanos não-funcionais. A proximidade física é indispensável à reprodução da estrutura social. A crescente separação entre as classes agrava distância social. Os homens vivem cada vez mais amontoados lado a lado

\footnotetext{
${ }^{61}$ Termo utilizado para fazer referência ao conjunto de parentes.
} 
em aglomerações monstruosos, mas estão isolados um dos outros.

A formação de novas aldeias não está ligada ao fator distância física, essa característica não é privilegiada. A articulação política regional entre aldeias faz-se independente das fronteiras e distâncias, constituindo-se o território Guarani uma rede de apoio e proteção contra os ataques sistemáticos impetrados por diferentes esferas e atores (LADEIRA, 2008).

Essa discussão também foi levantada por Adriano (2016), que considera a sociedade dos não índios contraditória. Coloca a questão da seguinte forma: "Que tipo de sociedade é esta que as pessoas não se conhecem". Segundo ele é incompreensível que as pessoas, cada dia mais, queiram viver nas cidades, nos apartamentos, mas não desenvolvem nenhum tipo de relação com as pessoas que estão próximas. O conceito de distância aqui é problematizado por Adriano (2016), visto que, para os Guarani, a proximidade representa a possibilidade de maior troca. No entanto, a distância entre as comunidades, dependendo do caso, não interrompe a ligação cultural que é também sustentada pelo compartilhamento da mesma cultura por meio de objetivos, rituais, organização e conhecimento.

Ainda com relação à ideia de redes, a pesquisadora Pascale de Robert (2004), ao estudar o significado do território dos índios Kayapó, analisou os desenhos que os indígenas construíram para representar e explicar as dinâmicas entre o território e a história de seu povo naquela região.

A autora aponta que:

Esses desenhos contam ao mesmo tempo as etapas da construção de um território e a história do grupo que a ocupa, na forma de um "esquema" geográfico em estrelas - constelações em um mundo sem limites. O território é apresentado como um espaço de relações sociais sem limites. [...] Mas a exatidão espacial ou temporal não é verdadeiramente importante para ele: é a palavra que conta, uma recitação ritual onde colocam nomes de lugares e nomes de chefes para contar a expansão territorial do povo mebengokrem, seus lugares e seus tempos (ROBERT, 2004, p. 3, tradução nossa). 
FIGURA 27: REPRESENTAÇÃO DO TERRITÓRIO POR KUPATÔ KAIAPÓ

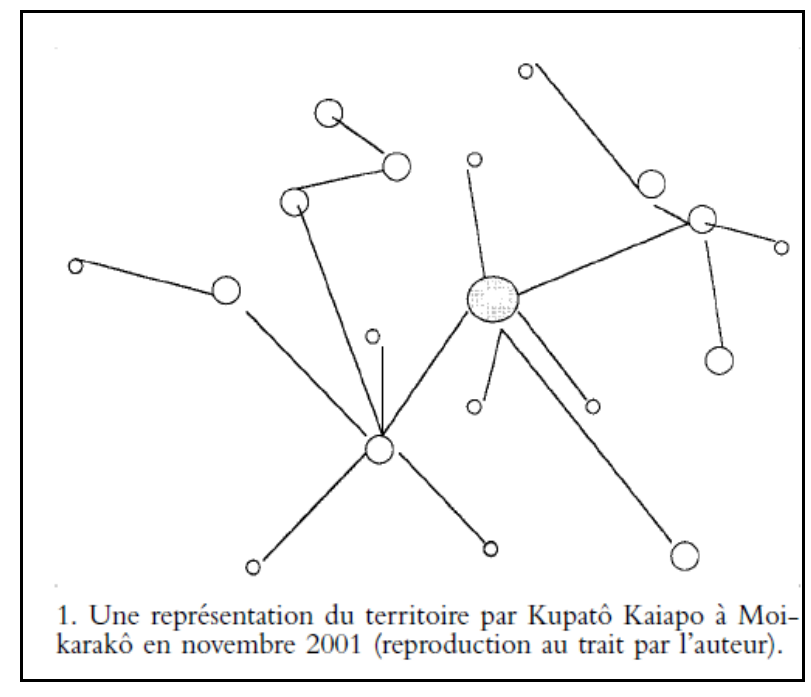

Fonte: ROBERT, 2004, p. 81.

\section{FIGURA 28: REPRESENTAÇÃO DESENVOLVIDA PARA O TERRITÓRIO GUARANI}

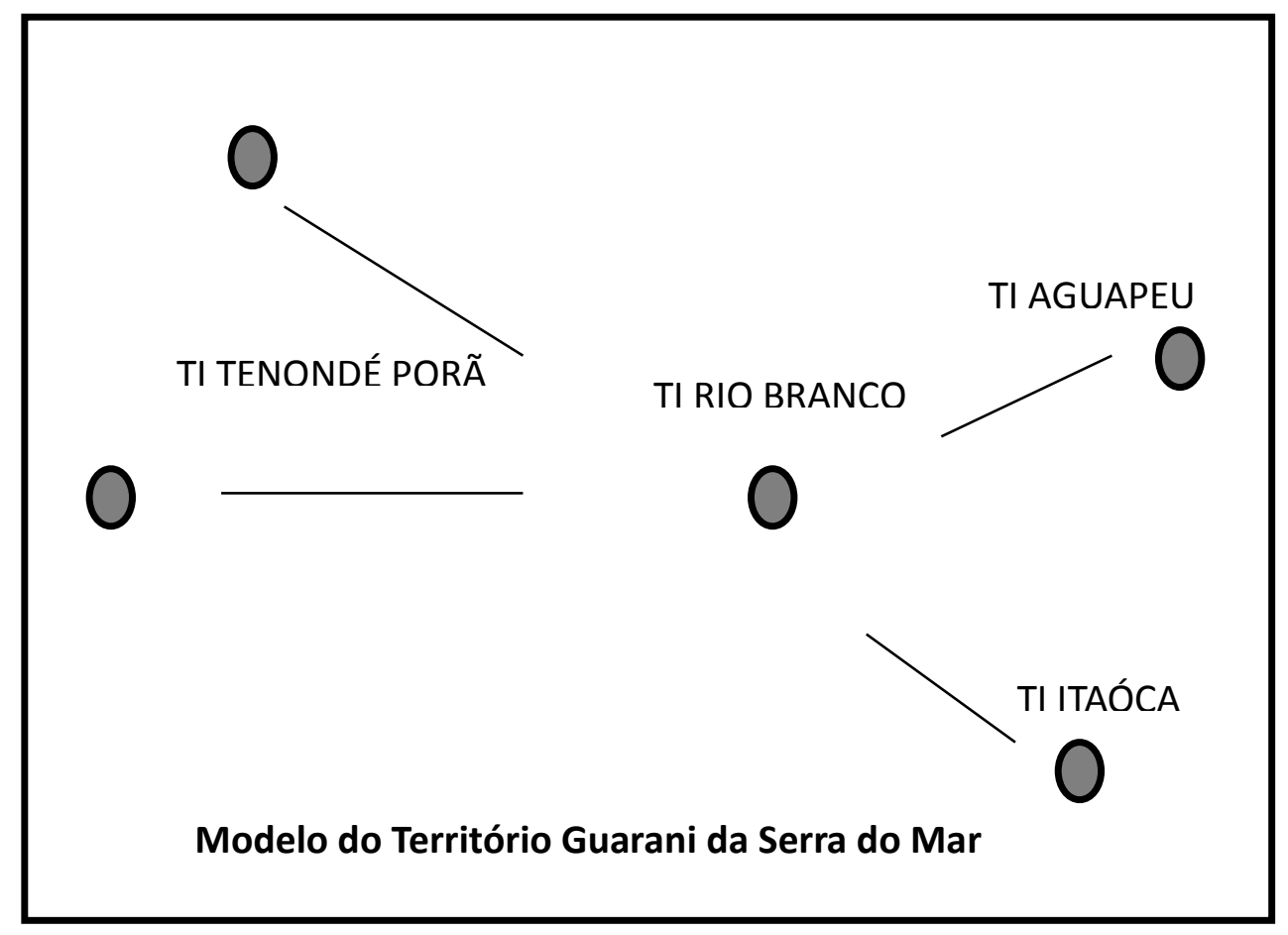

Fonte: Elaborado pelo autor. 
O esquema das comunidades em estrelas (figura 28) é bem representativo da ideia do território Guarani em redes, pois as aldeias permanentes são como nós dentro de um território que é configurado também por pontos transitórios. As aldeias transitórias não são ocupadas permanentemente, em sua maioria são pontos que permitem a circulação na área da Serra do Mar, como ponto de parada e de partida na lógica de mobilidade espacial Guarani.

\subsection{O TERRITÓRIO NO PONTO DE VISTA ZENITAL}


Figura 29: MAPA DO NÚCLEO HABITACIONAL POR ADRIANO KARAY POTY

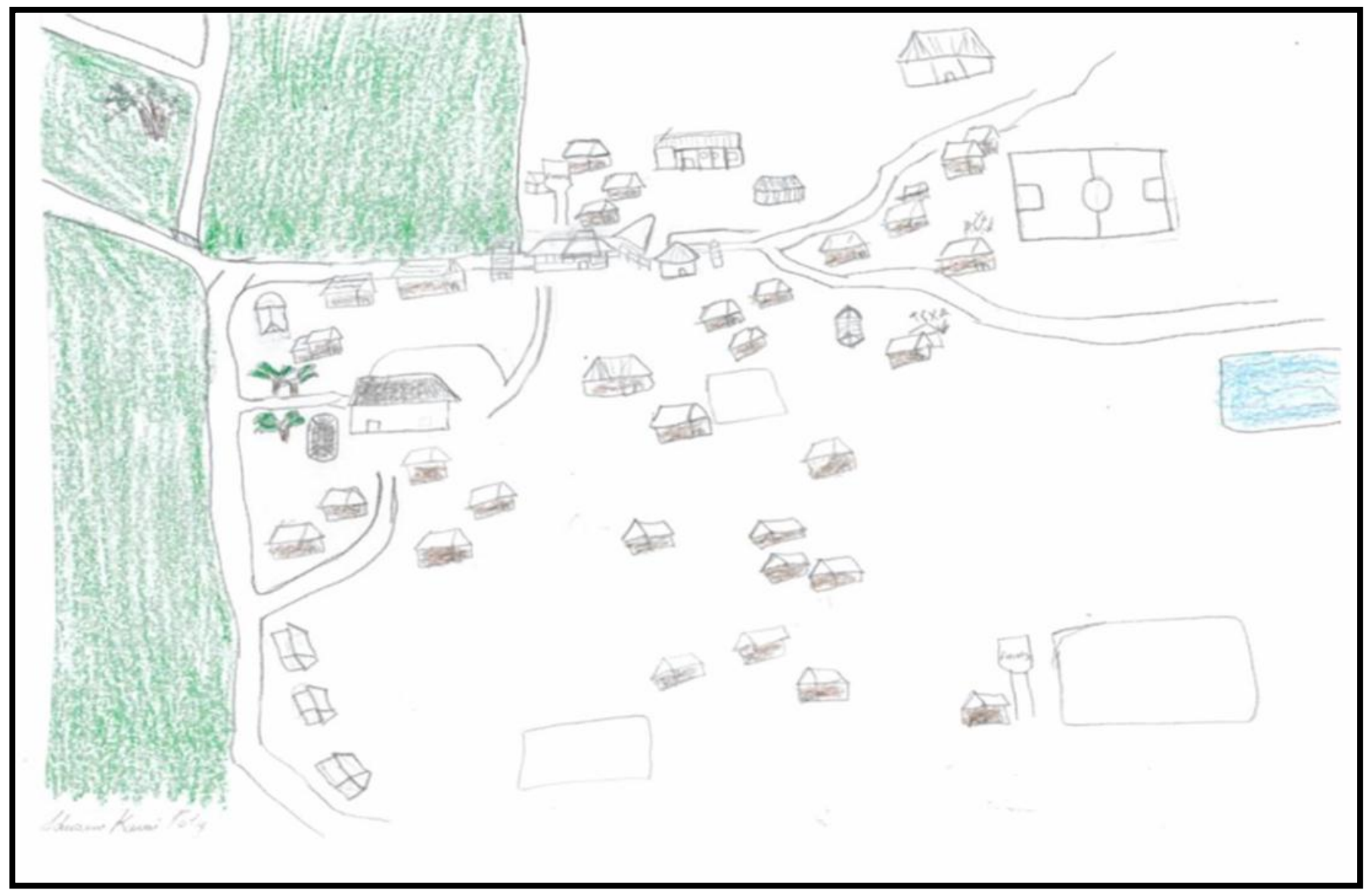

FONTE: Karay Poty, 30 anos, realizado em 17/09/2015; 
Figura 30: MAPA DO NÚCLEO HABITACIONAL POR EDMILSON KARAY POTY

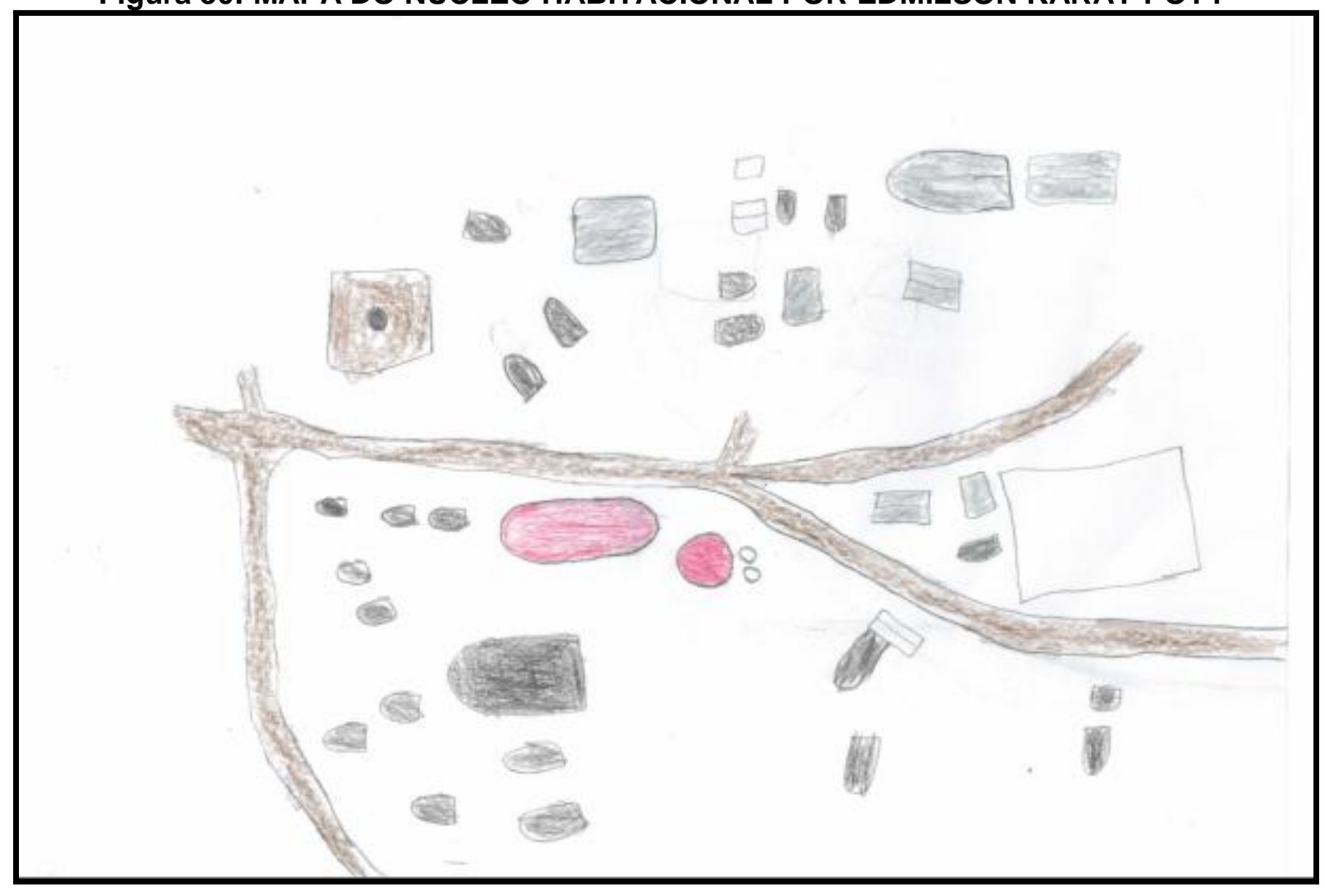

FONTE: Karay Poty, 19 anos, realizado em 17/09/2015. 
As duas representações (figura 29 e 30) são esquemáticas da comunidade, tendo as duas dois pontos de vista diferentes sobre o território. Os elementos iconográficos apresentados nas imagens são: as moradias, a escola CECI (Centro de Estudos de Cultura Indígena), a casa de reza, o campo de futebol, a área verde que se refere ao local de coleta de material para artesanato, a caixa de água da FUNASA (Fundação Nacional da Água), a localização de pés de bananeiras, que marca o início da área de retirada de materiais para artesanato, o açude existente e a escola estadual da comunidade.

Segundo o produtor do mapa, o núcleo central de moradias é marcado pela centralidade da casa de reza e as habitações que se organizam em torno dela. Essa questão colocada por Guarani é apresentada como um resultado muito significativo, um ponto alto, que faz todo sentido se investigado a importância da casa de reza para a comunidade.

A representação produzida pelo indígena de 19 anos (figura 30) é pensada de forma bem esquemática. Em sua representação, destacou-se a escola municipal $\mathrm{CECl}$ em vermelho e a casa de reza maior e em preto.

Obviamente estes dois espaços na comunidade têm bastante representatividade. Primeiro porque a casa de reza ocupa lugar central na forma de produzir e ocupar o núcleo habitacional, o que será abordado mais adiante. O segundo elemento em destaque na representação do Guarani de 19 anos é a presença, em vermelho, da escola que, embora seja uma imposição externa, representa o meio em que propicia a distribuição de alimentos e, até mesmo, de empregos e recursos provenientes da prefeitura de São Paulo para a comunidade, esta é uma forma de apropriação interna.

Com a falta do território para a produção de alimentos, os indígenas procuram ocupar cargos públicos dentro da comunidade para suprir a necessidade das famílias e da comunidade, visto que grande parte da comunidade necessita 
obter recursos fora dela, pois não é possível produzir alimentos em quantidade suficiente para sustentar a aldeia.

O desenho do Guarani de 19 anos é muito mais esquemático, com todos os elementos do ponto de vista zenital. Ele não teve nenhuma preparação escolar com mapas, mas ele fez a representação desta forma para exteriorizar o que ele considerava como território, e o que talvez ele ache que o pesquisador gostaria de ver, algo mais esquemático, já que se fala de uma comunidade que vem realizando um trabalho forte de politização dos jovens quanto aos conflitos atuais relacionados aos territórios indígenas.

Há encontros semanais, mensais e anuais com os jovens da comunidade que promovem palestras, discussões e danças tradicionais, com o intuito de preparar os jovens indígenas para a luta e difusão das questões relacionadas aos territórios Guarani como um direito e uma necessidade para a manutenção da cultura e como forma de resistência à pressão exercida pelos meios de comunicação, como a Internet, dentro da comunidade.

Nas representações referentes ao núcleo habitacional, observa-se que a escala de representação dos objetos, em geral, está condicionada à escala de representação da casa de reza. Ela tem uma simbologia fundamental para a cultura Guarani, revelando que o território é marcado pela sua existência. Ao representar o território, os Guarani partem da construção de mundo que ela dá sustentação. É nela, na casa de reza, onde tudo acontece: festividades, rituais, cerimônias e encontros:

São realizados em todas elas os rituais diários, que ocorrem nas casas de reza a partir do fim da tarde, nos quais são feitas as cerimônias de cura xamânica e os cantos e danças que visam à preparação corporal e o fortalecimento espiritual. Também são realizadas diferentes modalidades dos rituais de "batismo" ou nhemongarai, conforme são conhecidos na literatura, que celebram a passagem das estações (Ara Pyau e Ara Ymã). Dentre as modalidades mais praticadas está o Ka'a Xaim, ritual de batismo da erva-mate, e o Yy Karai, ocasião na qual é realizada a nominação das crianças. Cabe destacar também a realização do Mbojape Nhemongarai, ritual de batismo do "milho verdadeiro", que os Guarani da Tenondé Porã persistem em fazer, mesmo sem ter condições de plantar num volume suficiente para a confecção 
dos pãezinhos de milho (mbojape) para toda a comunidade, enquanto esperam que a regularização da TI Tenondé Porã propicie o espaço necessário para o plantio em quantidade suficiente para a manutenção de suas tradições (FUNAI, 2012) ${ }^{62}$.

A espacialidade, então, é influenciada e representada por meio da centralidade da casa de reza. Como observado nas duas representações anteriores, ela acaba por definir a organização do núcleo habitacional da aldeia. $\mathrm{Na}$ cosmovisão Guarani, a casa de reza representa o ponto central da comunidade, todas as moradias devem ser organizadas ao redor dela. Um exemplo de ritual que ocorre na casa de reza, vinculado às estações do ano e ao plantio de alimentos, é no final do inverno, ou a ara yma (inverno). Segundo Ladeira (2008, p.173):

No final de ara yma, sempre vem uma ventania (yvytu vaekue), anunciando os tempos novos. Nesse momento de passagem de um tempo/estação a outro, costumam realizar o kaa nhemoingue, o "batismo" das folhas de mate, ritual realizado na opy (casa de reza). O anúncio da entrada de ara pyau (verão) indica que a frequência na casa de reza se intensificará e, com isso, o uso da erva-mate, o que pede o ritual do kaa nhemoingue. Se nessa época houver, no tekoá, crianças ou adultos que precisem receber nomes, estes podem ser revelados, realizando-se conjuntamente 0 ritual do nheemongarai.

Os rituais realizados na casa de reza estão totalmente ligados à produção de determinados alimentos, as estações do ano e a organização das moradias que a circundam. A influência da casa de reza pode ser observada em outras representações que foram retiradas do trabalho de Ladeira (2008). Elas foram desenvolvidas em experiências de campo diversas, com outros objetivos, ratificando novamente a ideia na qual as representações estão intimamente ligadas ao pensamento coletivo do grupo, como segue na figura 31 .

\footnotetext{
62 Texto retirado do resumo do relatório de identificação e demarcação da Terra indígena Tekoá Tenondé Porá publicado no Diário Oficial da União.
} 
Figura 31: MAPA DA ALDEIA POR UM JOVEM GUARANI DO LITORAL

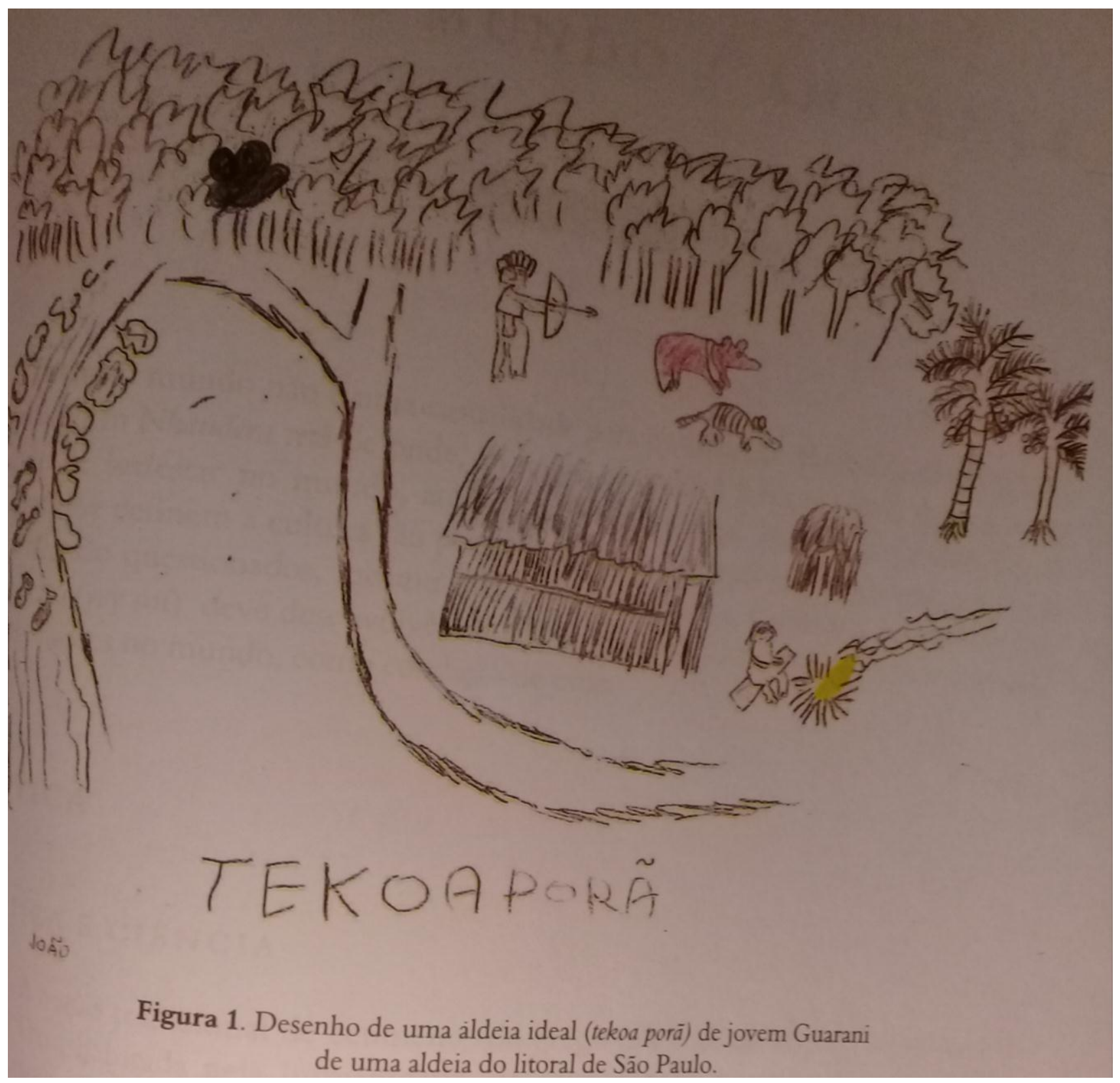

Fonte: Ladeira, 2008, p.128.

${ }^{63}$ Representação retirada da tese de Maria Inês Ladeira (2008, p. 128). 
Figura 32: MAPA DE ALDEIA POR UM INDÍGENA GUARANI

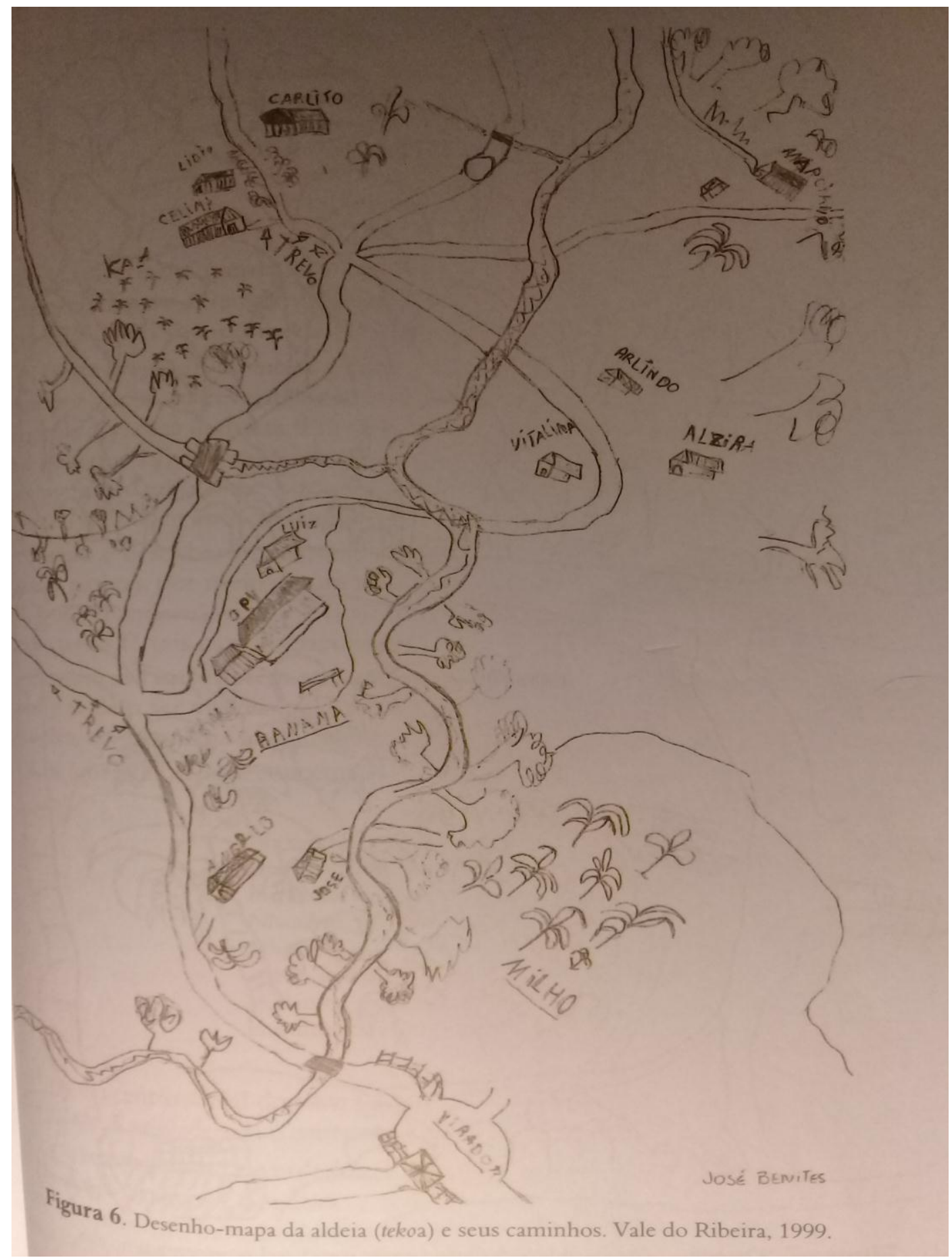

Fonte: Ladeira, 2008, p.128. 


\section{FIGURA 33: REPRESENTAÇÃO DO TERRITÓRIO}

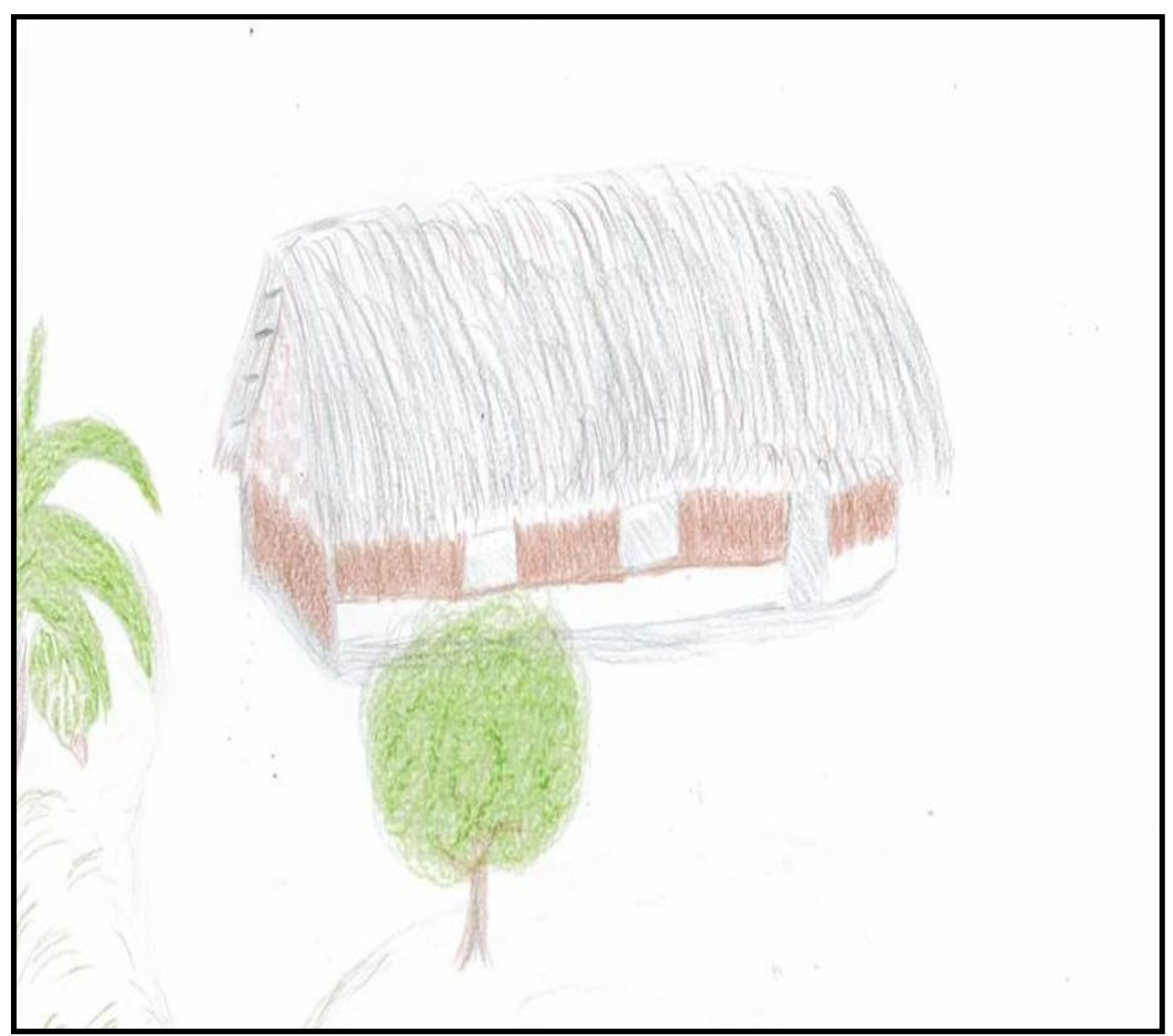

Fonte: Ronaldo Karai, 29 anos, realizado em 17/09/2015. 
A casa de reza é fundamental, pois ela ocupa sempre um lugar central na aldeia, sendo a maior dentre outros objetos representados. É interessante pontuar que, mesmo representações feitas em diferentes períodos e por diferentes sujeitos, em situações variadas, a casa de reza sempre aparece como testemunho de um pensamento que é compartilhado coletivamente entre os grupos indígenas Guarani. As duas representações presentes na tese de Ladeira (2008) serviram como um parâmetro de comparação para reforço dessa ideia, visto que a casa de reza está presente no imaginário de muitos Guarani e sua expressão visual é recorrentes em outras experiências.

$\mathrm{Na}$ última representação (figura 33), o Guarani que a produziu escolheu somente a casa de reza para demonstrar o que ele concebe ser seu território. Essa representação abstrata reforça ainda mais a ideia da casa de reza como um dos objetos sobre o território que exerce significativa, ou se não maior, influência na espacialidade do grupo por meio da cultura.

Além da visão oblíquo do território, como os figura 29 e 30, a representação das espacialidades podem adquirir, em diferentes contextos e concepções, outros pontos de vista, como é o caso da representação abstrata desenvolvida pelo Adriano e Edmilson (Guarani mbyá), que teve como centro somente a casa de reza. Portanto, os diversos pontos de vista são válidos e algumas vezes complementares para reforçar algum elemento recorrente observado em outras representações.

A representação da caça, da agricultura e dos rituais nas representações ratifica o uso dado por esses grupos ao território ligado ao desenvolvimento do modo de vida tradicional Guarani. Diante dessas constatações é necessária a discussão sobre a ampliação da Terra atualmente demarcada, como uma forma de proteção não só da Mata Atlântica, indispensável para retirada de material, alimentos e remédios, mas da cultura desses povos que como, se pode ver nas imagens, estão ligadas a elementos culturais Guarani diversos que fazem parte de uma representação de mundo. 
A escala de representação dos objetos deve ser observada, pois permite entender que tipo de informação se quer transmitir. A escala, como já foi pontuado, segue a lógica da cultura em relação aos sistemas de objetos que são criados e sua hierarquia no território e em cada núcleo habitacional. Portanto, assim como apontou os produtores dos mapas anteriores, as casas de reza determinam a localização, a organização e a proporcionalidade dos demais objetos no núcleo habitacional.

Essa diversidade de representações tem significativa importância para entender a própria forma de representação do território pelos Guarani, que não se limita a uma única forma de pensar o território, mas que demonstram ter alguns elementos simbólicos no território, é o caso da representação da casa de reza, que são recorrentes na maioria das representações selecionadas e que marca um pensamento que é coletivo entre esses grupos. 


\section{FIGURA 34: CASA DE REZA DA ALDEIA TENONDÉ PORÃ}

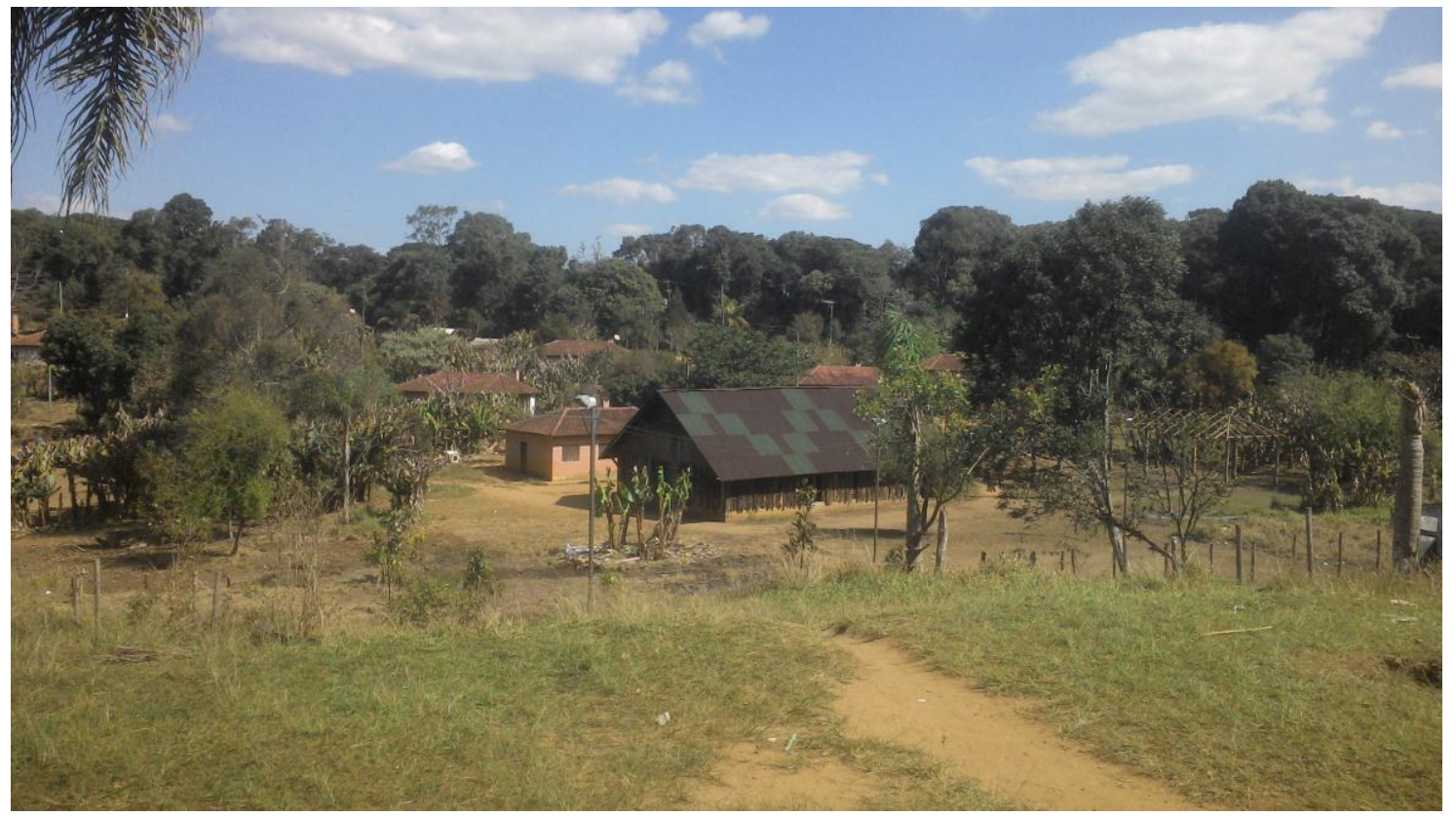

Fonte: Costa, 2016.

Segundo os indígenas da comunidade Tenondé Porã é necessário que haja maior atenção à casa de reza que, aos poucos, vai perdendo sentido. Isso se deve a constante ameaça da subtração dos seus territórios, o que impossibilita à manutenção da cultura Guarani.

Essa questão da necessidade do território para a manutenção da cultura é tão significativa que está ligada também a crenças religiosas dos Guarani. Segundo Ladeira (1998; 2001), a importância do território material como uma plataforma de sustentação do mundo indígena é tão profunda que nas profecias Guarani, caso não houvesse mais as aldeias com suas casas de reza, Nhanderu ${ }^{64}$ enviaria o fogo que destruiria a Terra atual ${ }^{65}$.

${ }^{64}$ Deus da mitologia guarani. 
A escola $\mathrm{CECl}$, que foi desenhada nas duas representações, também desempenha papel central na organização desse território. A construção dessa escola, que em um primeiro momento representou uma imposição da cultura externa, por outro possibilitou que a comunidade recriasse esse espaço para utilizar os recursos enviados pela Prefeitura para atender as crianças da comunidade, bem como, fomentar atividades ligadas à cultura.

Em 1978, com o apoio da Funai, foi construída pelos índios uma pequena escola de madeira na aldeia, que passou a funcionar por meio de um projeto de alfabetização do Centro de Trabalho Indigenista. No decorrer dos anos, a comunidade passou por várias experiências educacionais. Em 2004 a prefeitura de São Paulo construiu o Centro de Educação e Cultura Indígena (CECl), para crianças de 0 a 6 anos $^{66}$. A escola possuí 98 alunos matriculados e 3 salas de aula. Caracteriza-se por desenvolver atividades relacionadas à cultura Guarani. No site da prefeitura, órgão responsável, não há indicação de professores contratados. Porém é notório que boa parte dos professores pertence à comunidade.

\footnotetext{
${ }^{66}$ Retirado de www.escol.as/209794-tenonde-pora.
} 


\section{FIGURA 35: CEII / CECI TENONDÉ PORÃ}

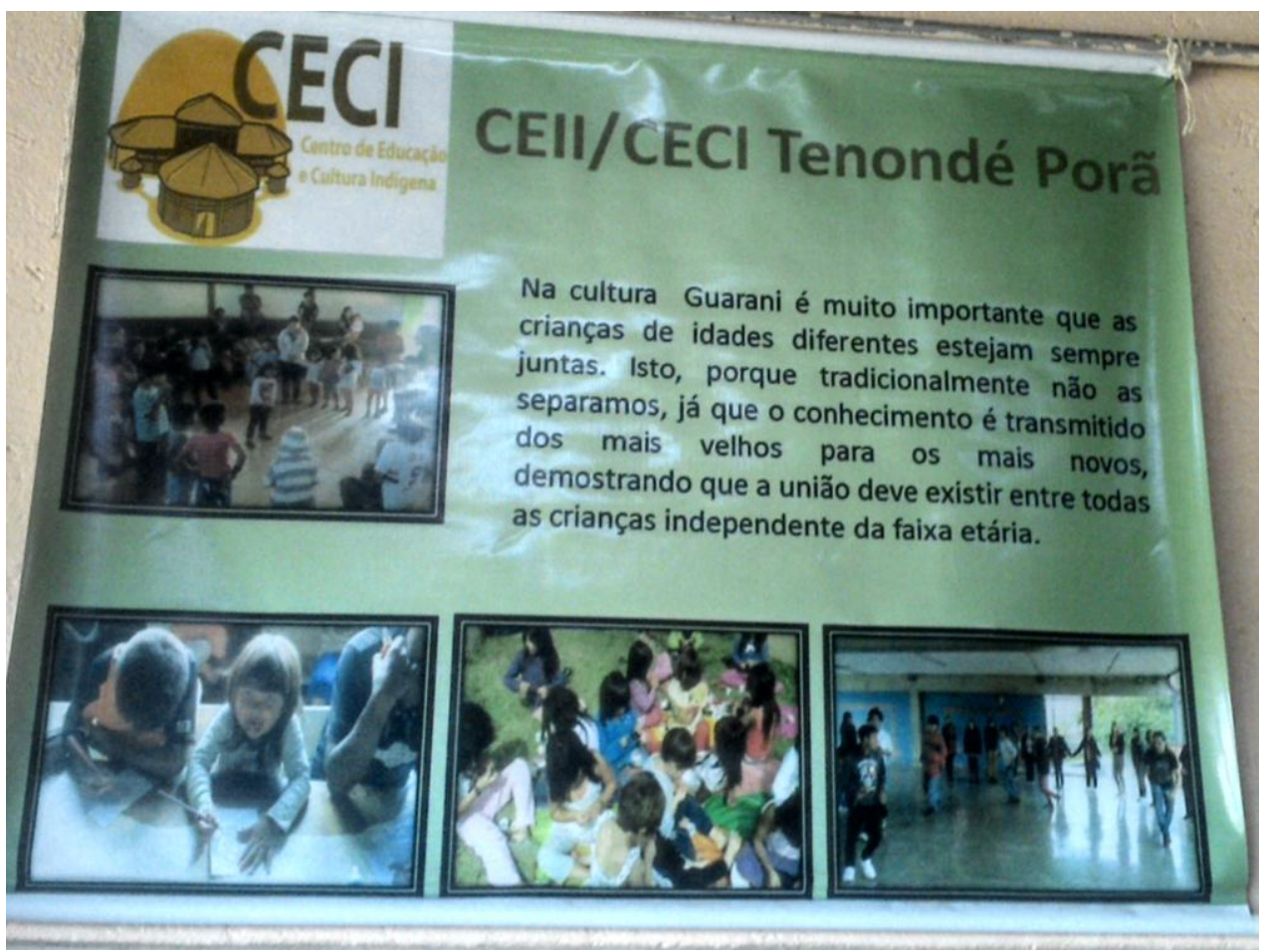

Fonte: Costa, 2016.

FIGURA 36: CENTRO DE EDUCAÇÃO E CULTURA INDÍGENA (CECI)

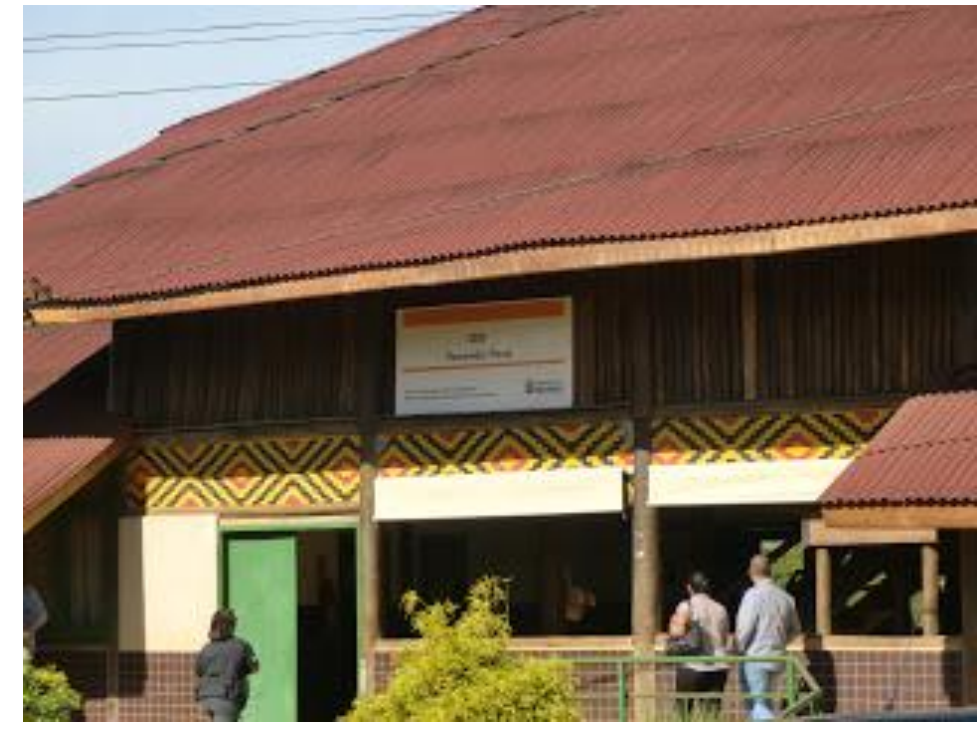

Fonte:www.telecentroaasd.blogspot.com.br (2017) ${ }^{67}$

${ }^{67}$ Acesso em: 06/12/2017. 


\section{FIGURA 37: ESCOLA ESTADUAL GUYRÁ - PEPÓ}

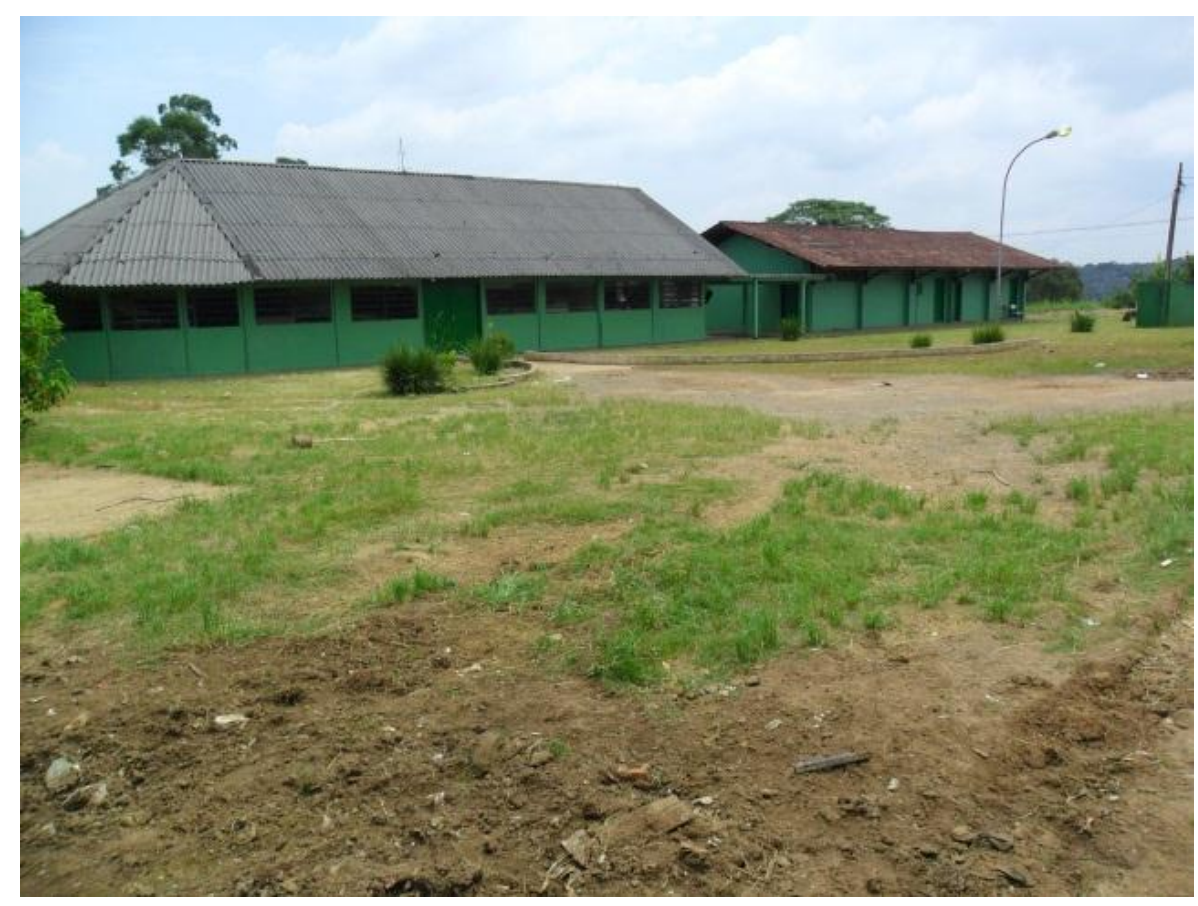

Fonte: COSTA, 2013

A importância do $\mathrm{CECl}$ e da escola estadual também se deve a um aspecto fundamental: a comunidade é composta majoritariamente por crianças e jovens. Segundo levantamentos da FUNAI (2012), entre os anos de 2005 e 2009 houve um aumento de $50 \%$ da população nos núcleos de habitação.

A presença da escola e do posto de saúde é uma contradição, se analisada a sua função em contextos históricos distintos. Antes, a escola e o posto de saúde eram encarados como uma ameaça à manutenção da cultura Guarani. Como assinalado anteriormente, a dificuldade dos Guarani de se manterem com recursos financeiros próprios, a falta do território para desenvolver o artesanato e a agricultura, força essas comunidades a inserir-se no mercado de trabalho fora da aldeia e dentro dela, como professor, coordenador, auxiliar de serviços gerais e agente de saúde nas escolas da comunidade, no posto de saúde, no $\mathrm{CECl}$ e na Escola estadual da comunidade. 
Outra questão central que envolve a presença da escola CECI é o fato de que muitas crianças da aldeia se alimentam na escola, então boa parte do alimento oferecido às crianças vem de recursos financeiros que vem das escolas. Essa questão merece estudos mais aprofundados, o que não é nosso objetivo, visto que muitos indígenas são contra a presença das escolas e do posto de saúde ainda hoje. No entanto, outros já concordam com a presença.

Desse modo, se há pontos negativos a serem assinalados a respeito da presença da escola dentro da comunidade há, também, pontos positivos: como as necessidades fundamentais de parte da comunidade que estão sendo supridas pela escola, no caso a alimentação das crianças, que é distribuída por meio desse espaço.

Essas duas representações (figuras 29 e 30) levantam questões que são fundamentais, quando se pretende entender melhor a questão das espacialidades da comunidade.. Pensar essa organização pressupõe entender o que significa distância e fronteira para os Guarani, e como isso se reflete nessa organização do território em redes, baseado na parentela e nas trocas. O território só é entendido quando essas variáveis estão claras, pois a definição Guarani de território dialoga necessariamente com esses conceitos.

Para concluir, toca-se na discussão da razão da ausência ou presença dos elementos iconográficos nas representações, e, para isso, mobilizou-se os conceitos de paisagens visíveis e invisíveis, apresentados por Gould e White (1974). As "paisagens invisíveis" é um conceito empregado na obra para falar daquilo que não foi transferido para o papel, as paisagens que estão na memória dos grupos, mas que não necessariamente foram transferidas para o papel.

As paisagens invisíveis de Gould e White (1974) é explicativo no caso das representações produzidas pelos Guarani, ilustrando melhor a questão: Devido ao fato das representações produzidas somente conter o núcleo habitacional é lógico pensar que aquela pequena área é suficiente para a comunidade, posto que não aparece a representação da Serra do Mar, ela supostamente não estaria presente no imaginário dessas comunidades. Essa seria uma leitura errônea, que descarta os contextos que essas imagens estão inseridas. Gould e White (1974) colocam 
que há paisagens que são invisíveis nas representações, mas que isso não significa que ela seja menos importante, ou que ela não esteja presente na mentalidade da comunidade. Pelo contrário, ela é uma paisagem invisível, e que por alguma questão ou interesse ela foi ocultada, mas sua ausência não anula a sua existência no imaginário coletivo da comunidade e sua importância.

Concluindo, não é possível compreender essas representações fora dos seus contextos de criação, assim como é difícil entender seu significado sem compreender o contexto cultural que elas estão inseridas, como havia salientado Harley (2005). 


\subsection{A REPRESENTAÇÃO DOS PROBLEMAS AMBIENTAIS: CAMINHOS PARA DA PRESERVAÇÃO}

Figura 38: MAPA DO NÚCLEO HABITACIONAL POR UMA GUARANI

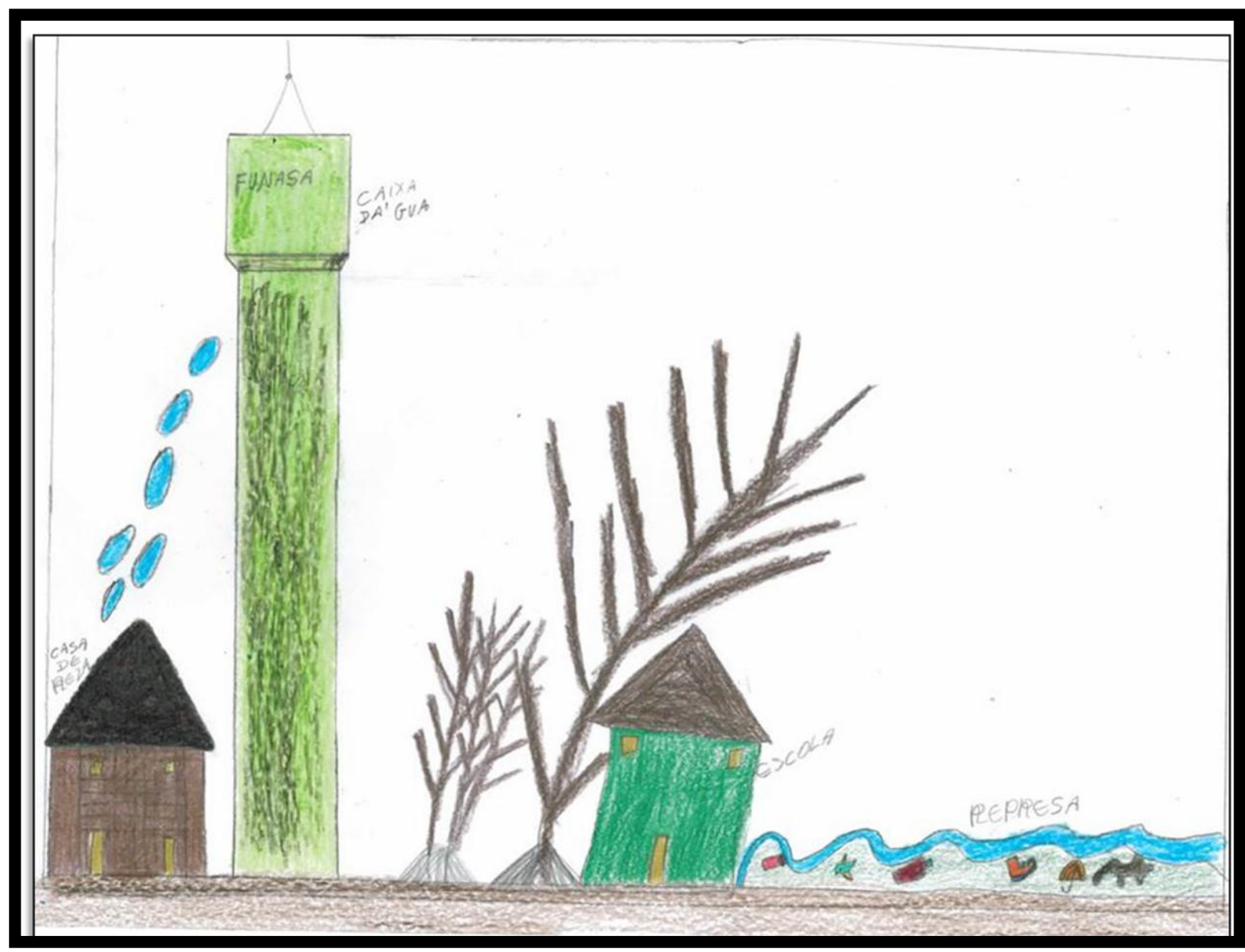

Fonte: Claudia $4^{68}, 31$ ano, realizado em 17/09/201569.

Segundo a indígena Guarani que desenvolveu esta última representação:

Este desenho representa dois problemas gravíssimos existentes na comunidade. Primeiro a poluição da represa Billings e segundo

${ }^{68}$ Claudia Guarani mbyá é estudante de pedagogia e moradora da aldeia tenondé Porá.

${ }^{69}$ As anotações na imagem foram feitas pela Guarani que a produziu. 
o desperdício de água pela caixa de água que acaba por alagar a comunidade. Isso representa um problema forte pra comunidade, pois é fundamental manter essa represa limpa para a comunidade (Guarani, 2015, entrevista).

Ela relata dois aspectos: o vazamento de água de uma das caixas de água da FUNASA, o que causa alagamento de parte da comunidade, chegando água até a casa de reza à esquerda na imagem. A representação da represa Billings denuncia a poluição que é gerada devido ao esgoto clandestino não tratado lançado na represa.

\section{FIGURA 39: VISTA DA COMUNIDADE TENONDÉ PORÃ}

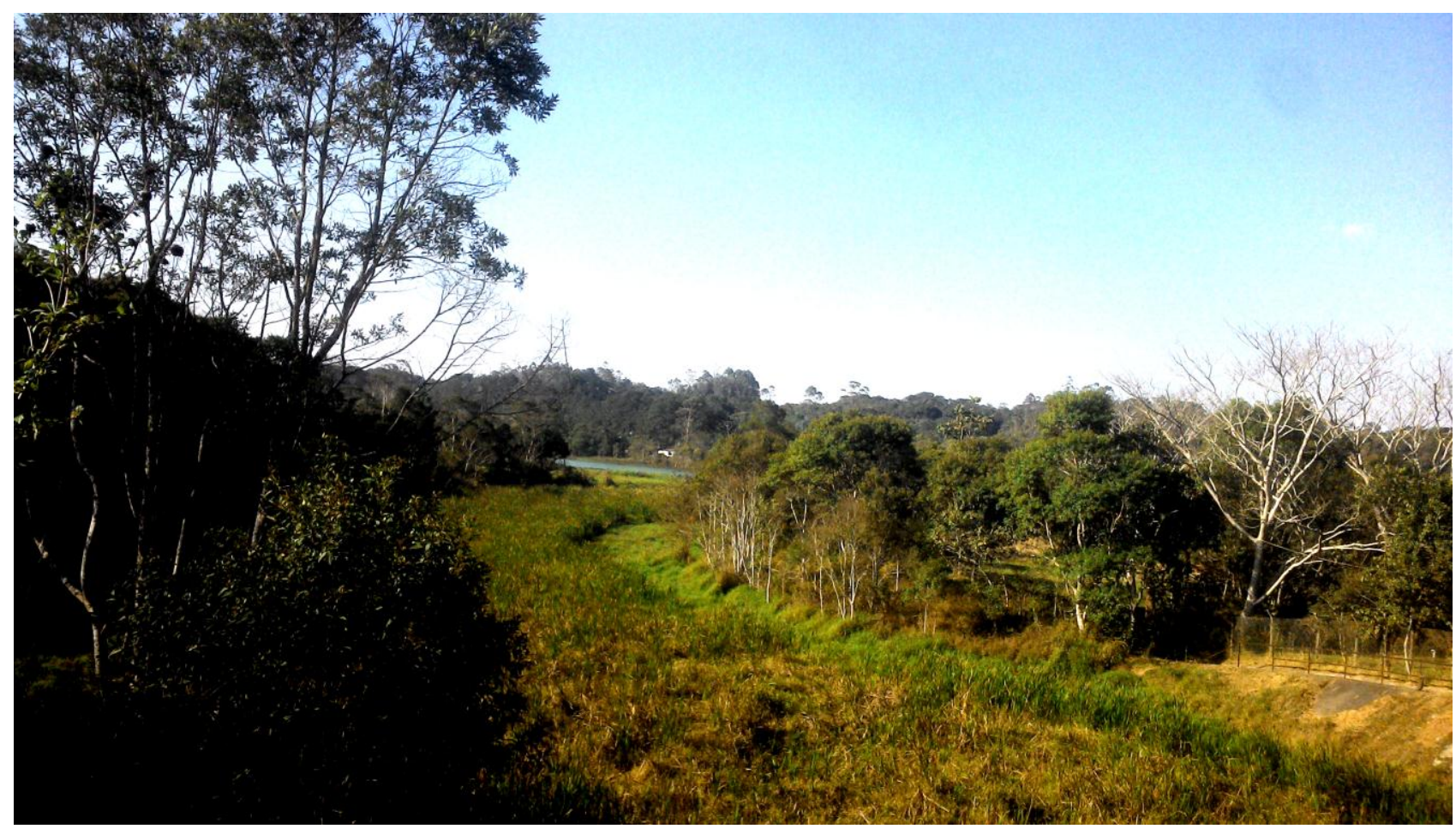

Fonte: Costa, 2016.

Importante notar que a casa de reza e a escola não ficaram de fora da representação, mesmo tendo como objetivo principal da imagem alertar sobre dois problemas ambientais gravíssimos existentes e que se refletem negativamente na 
comunidade, a casa de reza aparece sendo ameaçada pelo vazamento de água da caixa de água instalada na comunidade pela FUNASA.

Essa sensibilidade com relação à represa e aos rios que cortam a comunidade devem ser interpretadas como algo ancestral e que tem um marco histórico na relação do Guarani com o território ocupado.

Foi possível relacionar representação e discurso e constatar que, historicamente, os Guarani mbyá ocuparam as várzeas e vales dos rios das bacias hidrográficas da Billings e da Capivari-Monos. Segundo pesquisa antropológica da FUNAI "A memória oral dos indígenas da região indica a aldeia Yyrexakã, localizada no Vale do Rio Capivari, como principal ocupação dos Guarani na região entre as décadas de 1940 e 1950 (Diário Oficial da União, 2012, p. 20)". Portanto, é importante notar que as aldeias permanentes, bem como as transitórias, estão organizadas próximo dos cursos de água, o que permite os Guarani manter proximidade com esse elemento da natureza.

Esse cenário pode ser ilustrado por meio do depoimento dado, por um cacique da aldeia Aguapeú, para o governador do Estado de São Paulo em relação ao projeto de esgoto para a região de Mongaguá, em 1988 (LADEIRA, 2008, p. 110) $)^{70}$ :

[...] Nós índios sabemos que o rio pertence à aldeia, e é esse rio (rio Aguapeú), que divide a nossa Terra da cidade, que é o guardião da aldeia, protegendo a comunidade. Na nossa cultura, no nosso costume, é o rio que não deixa passar o mal, a doença, nem aquelas pessoas que querem nos prejudicar. Então, para nós, o rio é sagrado. Não se pode entregar, nem mexer, nem vender o que o dinheiro não paga. Somente Nhanderu (o nosso pai celestial) é que sabe o que vai fazer com o próprio rio.

Os rios são elementos centrais para a reprodução material e simbólica dos povos indígenas, ribeirinhos e tradicionais. Como se observa na representação e na fala dos Guarani, os rios estão presentes nos mitos de criação da cultura. Há também a diferenciação entre importância e a influência da Terra, do rio, do mar e

${ }^{70}$ Retirado da tese de Maria Inês Ladeira (2008). 
da mata na ocupação do território pelos Guarani. Segundo estudos realizados por Diegues (2007, p.1) "Presente na criação do mundo, as águas são consideradas dádivas divinas abundantes e por isso mesmo o seu desaparecimento significa 0 fim da própria sociedade".

FIGURA 40: REPRESENTAÇÃO DO ARTESANATO E COSMOLOGIA POR MARCIO MIRIM

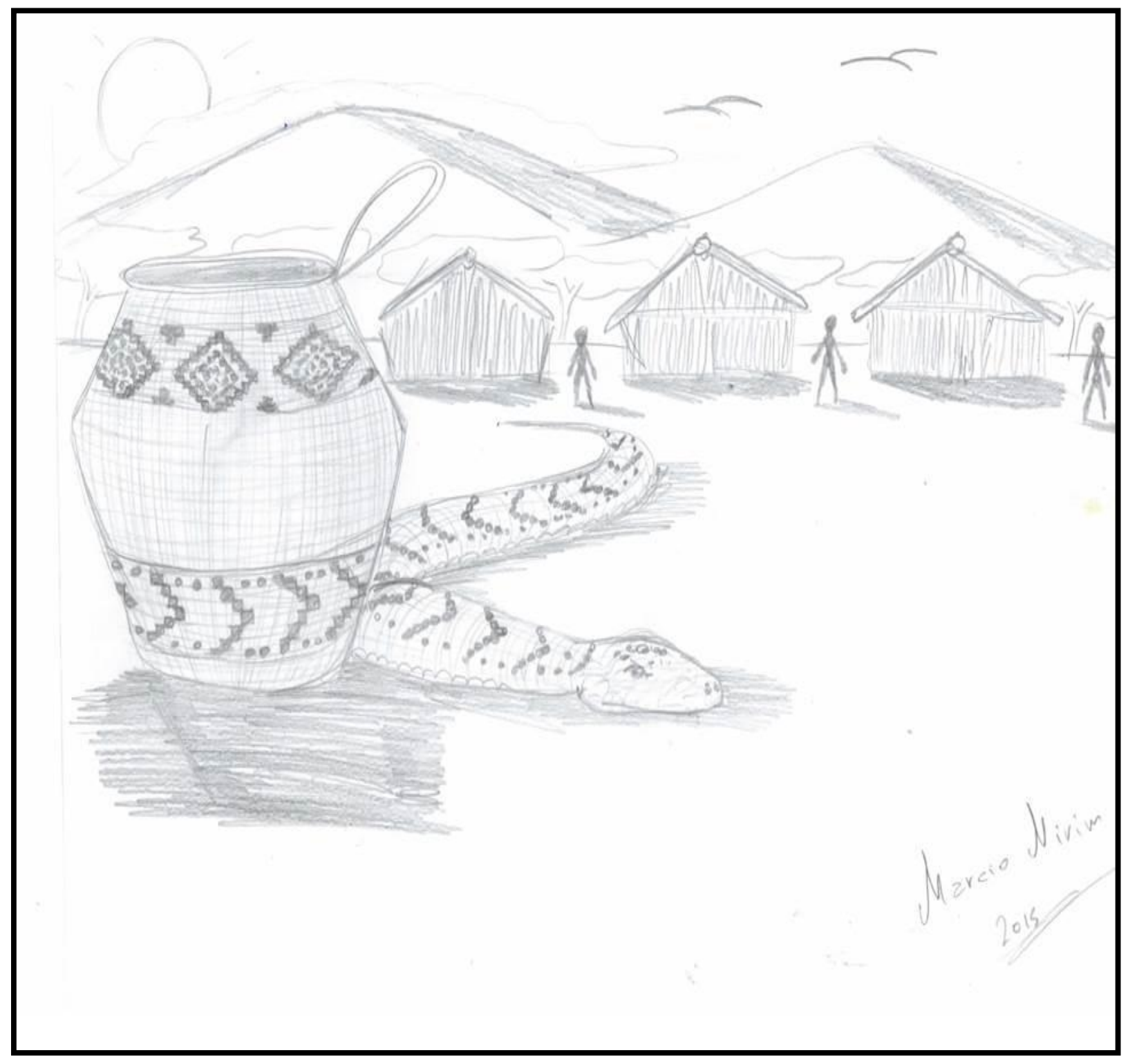

FONTE: Marcio Mirim, 24 anos, realizado em 17/09/2015. 
FIGURA 41: ARTESANATO GUARANI

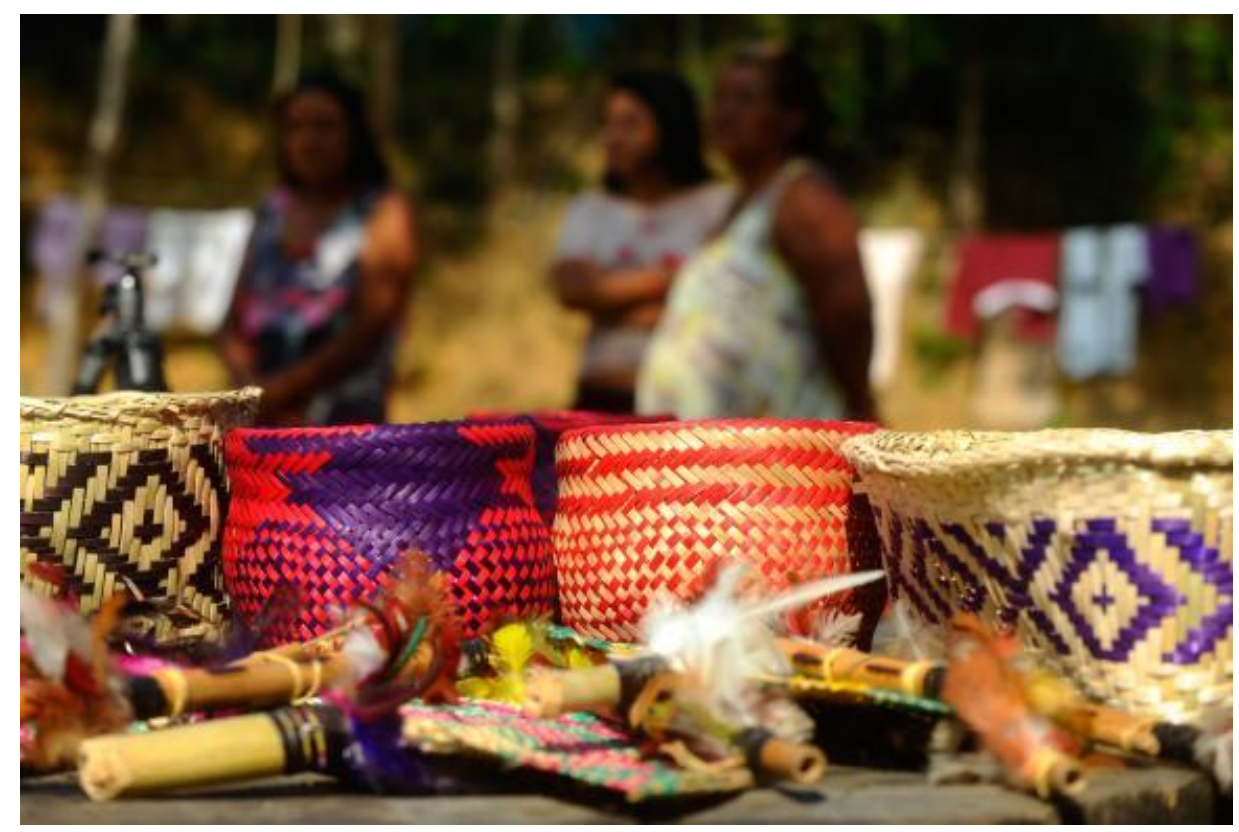

Fonte: http://agenciabrasil.ebc.com.br/

Segundo moradora da comunidade Claudia (2014, entrevista), os rios, assim como os solos estão impróprios para uso da comunidade devido à forma que a sociedade dos não índios se apropriam desses elementos da natureza, de forma predatória e destruidora, diferente do modo que os Guarani acreditam ser viável utilizar os recursos que a natureza pode prover. "O rio que temos aqui foi poluído, mas ainda pescamos ali, porque não há outra alternativa. O solo está contaminado, mas o governo não nos ouve"

O artesanato e o turismo são duas atividades desenvolvidas pela comunidade que, se analisadas em uma ótica para além da manutenção da comunidade, são duas atividades estratégicas para a manutenção das florestas e dos rios que fazem parte das comunidades, como apontado anteriormente. Para os Guarani sem a preservação da natureza não é possível desenvolver os materiais que produzem, provenientes de florestas e rios preservados. Essa visão encontra ressonância na chamada ecologia social tratada por Diegues (2001) que 
vê nas práticas tradicionais das populações um excelente instrumento de preservação da natureza.

Esta afirma que as sociedades tradicionais requerem alta diversidade de recursos naturais e que estas sociedades ainda existem porque desenvolveram práticas culturais de utilização dos recursos que mantêm a biodiversidade. Consequentemente, assegurar a sobrevivência dessas práticas é um excelente método para conservar a diversidade biológica (DIEGUES, 2001, p. 11).

Mas ver nos territórios indígenas a possibilidade de preservação da natureza é uma questão bem polêmica, pois há divergência.

Os impactos ambientais na Terra indígena são muitos e foram agravados por diversas razões, dentre elas: o alagamento da represa Billings desde 1927; a antiga rodovia Sorocaba; a Rodovia dos Imigrantes; as linhas de transmissão Tijuco - Preto; e o trecho sul do rodoanel. A construção de rodovias e as obras de infraestrutura citadas acima têm gerado novos empreendimentos na região, isso pode ser observado no loteamento do entorno do próprio Parque Estadual da Serra do Mar, como foi salientado anteriormente. Em decorrência desse cenário é interessante assinalar o espraiamento da mancha urbana, consequência dos loteamentos irregulares, como um grande fator de pressão sobre as comunidades e os rios.

Em razão do modelo de desenvolvimento, obras de saneamento e abastecimento de água, sistemas de transmissão de energia elétrica, construção de rodovias (Rio - Santo, BR-101). Barragens, usinas nucleares, Rodoanel, Gasoduto Bolívia-Brasil, entre outras, impactam os recursos naturais das Terras indígenas e suas comunidades (LADEIRA, 2003, p. 7).

A produção de artesanato nas comunidades Guarani tem uma ligação profunda com a cosmologia. Para nossa sociedade, as atividades de trabalho, em função da lógica de acumulação, degradam o meio ambiente, na cultura Guarani, por outro lado, os materiais produzidos, por meio do trabalho, refletem a organização da comunidade e, ao mesmo tempo, revelam sua relação com a 
natureza, que está ligada aos rituais e as festividades. Essa constatação, também foi feita em pesquisas realizadas com outros grupos indígenas do Brasil.

Mas todas as atividades produtivas contêm e combinam formas materiais e simbólicas com as quais os grupos humanos agem sobre o território. $O$ trabalho que recria continuamente essas relações reúne aspectos visíveis e invisíveis, daí porque está longe de ser uma realidade simplesmente econômica. Nas sociedades ditas "tradicionais" e no seio de certos grupos agroextrativos, o trabalho encerra dimensões múltiplas, reunindo elementos técnicos com o mágico, o ritual, e enfim, o simbólico (CASTRO, 2000, p.167).

O turismo e o artesanato são duas formas de gerar renda para a comunidade e, portanto, tornam-se instrumentos centrais para galgar relativa autonomia. É uma forma de fugir do mercado de trabalho que muitas vezes os índios são obrigados a inserir-se devido à falta de recursos para manutenção das famílias. A produção de artesanato está condicionada à existência de material que não tem em abundância na área, pois trata-se de uma Terra demarcada com um território reduzido, fragmentado e de pouco solo fértil para a manutenção da comunidade, como foi enfatizado no decorrer desta pesquisa. Portanto, a principal atividade econômica, o artesanato, fica comprometida, bem como a utilização dos rios e solos.

Os povos Guarani dispersos pelo Brasil, Argentina, Paraguai e Uruguai ocupam uma extensa faixa da Mata Atlântica. Por isso, sua relação tão íntima com essa natureza que por consequência faz com que suas representações dialoguem necessariamente com ela, como é possível observar a semelhança entre o artesanato e a cobra na representação desenvolvida (figura 40), uma simbiose entre flora e fauna, esta vista como um sujeito produtor de uma dada ordem espacial.

A diferença existente nessas representações, tornando-as singulares em relação a outras representações reside nas percepções sobre a natureza por parte de quem as produz. Na ciência moderna a natureza é vista como "recurso natural", enquanto que os grupos indígenas a consideram um conjunto de seres vivos, 
sujeitos dotados de valor simbólico. Essa questão já havia sido demonstrada por Pardini (2012, p. 592):

Estudos antropológicos mostram que as sociedades indígenas da planície amazônica, via de regra, conferem aos animais e às plantas os caracteres subjetivos da pessoa humana: consciência de si, motivações, afetos, capacidade comunicativa e sociabilidade e, com eles, estabelecem relações de pessoa para pessoa, idênticas àquelas que os humanos mantêm entre si.

Essa fala de Pardini (2012) é bem ilustrativa do caso da representação de uma cobra da última imagem (figura 40). O animal, assim como o cesto, tem as mesmas características na representação, isso equivale a dizer que o artesanato é como uma extensão da natureza, representada nesse caso pelos traçados do corpo da cobra que são os mesmos para o desenho dos artesanatos. Segundo Adriano (2017, entrevista), "a cobra é dona dos rios e tem grande respeito dos Guarani”. Portanto, observando as imagens e as falas dos Guarani, é possível identificar a conexão entre essas representações. A cobra, assim como os rios, fazem parte das representações de mundo dos Guarani mbyá.

As representações têm conexão entre elas, pois foram criadas dentro de um contexto social específico, guardando entre si relações. As representações só são legíveis para o outro, o não indígena, quando se busca entender mais da cultura a partir do que as representações revelam. Quem colocou as questões que foram discutidas foram as representações, pois se pretende realizar uma leitura a partir de experiências cartográficas. O material oral e a bibliografia embasa, referenda e referenda aquilo que foi exposto cartograficamente, torna a representação legível para o não indígena. 


\section{CONSIDERAÇÕES FINAIS}

O que se apresenta nesta pesquisa é um exercício metodológico que envolveu pesquisa bibliográfica, vivência de campo, entrevistas e a utilização de representações diversas para a interpretação e leitura da concepção de território Guarani. Ao final da pesquisa é possível identificar algumas questões que foram fundamentais para entender a constituição, fragmentação e retomada desse território e suas representações.

O território Guarani hoje se encontra fragmentado em pequenas ilhas de Terras, impedindo o desenvolvimento do modo de ser tradicional baseado na agricultura, na pesca e na coleta de materiais. Essa fragmentação acarreta conflitos intensos em alguns casos, em outras ela subtrai a possibilidade de relativa autonomia pelas comunidades, essa é uma problemática geral entre os povos indígenas. Portanto, o território Guarani não é sinônimo de Terra indígena.

Quando se fala do território Guarani da Serra do Mar tem-se em vista um situação fundiária singular, onde existe uma área contínua, ou seja, um território, considerando quatro Terras indígenas localizadas nessa região: Aguapeú, Rio Branco, Itaóca e Tenondé Porá. O que apontou Gomide (2008, p. 399) para a questão do território Xavante vale para a questão Guarani: "[...] as Terras indígenas Xavante voltem a ter a configuração de território contínuo, por meio da implantação do Marãna Bododi, unindo as Terras indígenas por meio dos cerrados reconstituindo a territorialidade indígena". Para que as Terras indígenas voltem a ter a configuração de parte do território Guarani contínuo, por meio do nhadereko, deve-se unir essas Terras para a reconstituição do modo de ser tradicional.

Essas questões foram tratadas nos capítulos da dissertação, tendo o capítulo um abordado de forma geral o universo da cartografia em Geografia e as novas tendências metodológicas no desenvolvimento de mapeamentos participativos.

As representações do território Guarani demandam entender o contexto social, político e cultural que estão inseridos esses grupos. Cada comunidade vive 
e habita um território diferente, e dependendo da sua localização geográfica, as questões territoriais são diferentes. Entender o aspecto cultural é fundamental para entender as representações, pois é como um suporte para entender melhor as expressões cartográficas, bem como a própria fala e retórica utilizada pelos grupos Guarani quando se trata de defender seus territórios.

As representações Guarani revelaram o seu poder como um discurso individual e que ao mesmo tempo é coletivo. Representa um território real que é efetivamente apropriado de forma material e simbólica pelos povos Guarani da Serra do Mar. Ele é apropriado de forma objetiva quando se verificam a toponímias, as trilhas, as classificações em Guarani da fauna e da flora, as aldeias transitórias como estratégia de ocupação, bem como as aldeias permanentes como ponto estratégico dentro de um território muito mais amplo que o conectado por meio das redes.

Os elementos presentes nas representações do território, que não estão limitados ao núcleo habitacional, transcendem as fronteiras e distâncias quilométricas por meio das redes de parentesco e de trocas de mercadorias e conhecimentos. Esse território também é ligado por meio das articulações políticas que se dão em nível nacional e internacional, subvertendo o significado das fronteiras quando se trata da circulação e mobilidade, característica central desses grupos. Da mesma forma, os elementos subjetivos são diversos e estão relacionados à apropriação simbólica do território. Os rituais, as festas e a língua são formas de expressão de uma realidade subjetiva que passa pela apropriação simbólica desse território.

As apostas cartográficas realizadas permitiram responder as principais questões colocadas nesta pesquisa, constituindo-se em um exercício metodológico rico em informações e sugestivo de questões, referendando o papel do mapa como um polo consistente de um discurso (FONSECA; GIRARDI, 2016). No dia 5/5/2017 foi finalmente assinada a portaria declaratória da Terra indígena Tenondé Porá, faltando somente a homologação da Terra que corresponde à última etapa para finalização do processo de ampliação dos limites territoriais. No 
entanto, as perspectivas não são muito boas, visto o contexto de instabilidade político vivenciado no Brasil.

Com relação às questões colocadas inicialmente, as representações pensadas de forma isolada não justificam a ampliação da Terra indígena Tenondé Porã, mas, se analisadas e relacionadas com seus contextos, tornam-se fundamentais como material complementar para o desenvolvimento de estudo de reconhecimento ou ampliação de Terra. Esse estudo também é um exemplo dos primeiros passos que podem ser tomados quando se pretende trabalhar com cartografia participativa e comunidades indígenas.

Foi possível observar que é impossível esgotar as discussões a respeito dos contextos que envolvem a comunidade, e que muitos pontos levantados não foram aprofundados o necessário, como a questão fundiária e os trâmites jurídicos envolvidos.

Este trabalho se reflete na comunidade não pela sua materialidade, como se pontuou anteriormente, mas pela construção das relações que ora foram desenvolvidas e que futuramente poderão ser aprofundadas.

Essas considerações são finalizadas reforçando que esta pesquisa é, somente, uma leitura da problemática indígena por meio de um caminho metodológico, o qual está pautado na representação e na vivência indígena Guarani do território. 


\section{REFERÊNCIAS BIBLIOGRÁFICAS}

ACSELRAD, Henri (org.). Cartografias sociais e território. Rio de Janeiro: UFRJ/IPPUR, 2008.2 Disponível em: http://www.ettern.ippur.ufri.br/publicacoes/58/cartografias-sociais-e-territorio

ALBERT, Bruce. Pacificando o Branco: Cosmologias do contato no NorteAmazônico. São Paulo: Editora UNESP, 2002.

ALKMIN, Fábio M. Por uma geografia da autonomia: a experiência de autonomia territorial zapatista em Chiapas, México.Dissertação (Mestrado em Geografia Humana) - Faculdade de Filosofia, Letras e Ciências Humanas, Universidade de São Paulo, 2014

ALMEIDA, Alfredo Wagner Berno de. Carajás: A Guerra dos Mapas. Belém: 2a. Ed.: Supercores, 1995.

ANDERSON, Benedict. Censo, mapa museu. In: Comunidades imaginadas: Reflexões sobre a origem e a difusão do nacionalismo. São Paulo, Companhia das Letras, 2008. p: 226-255

BALÉE, William. Sobre a indigeneidade das Paisagens. Revista de Arqueologia. 2008. 21, n.2: 09-23,.

BATALLA, Guillermo Bonfil. México Profundo: Una civilización negada. México: Centro de Investigaciones y Estudios Superiores en Antropología Social, Ciesas, 1987.

BAVARESCO, Andréia Almeida. O pjê e a Cartografia: Os Mapeamentos Participativos como ferramenta pedagógica no diálogo entre saberes ambientais. Brasília: Dissertação de mestrado apresentada a Universidade de. 2009.

FELDMAN-BIANCO, BELA e LEITE, Miriam Moreira L. (orgs.).Desafios da imagem. Fotografia, iconografia e vídeo nas ciências sociais. São Paulo: Papirus, 1998, $319 \mathrm{p}$.

BURINI, Federica. La Cartographie Participative et la Pratique du Terrain Dans la Coopération Environnementale: La Restitution des Savoirs Traditionnels des Villages de I'Afrique Subsaharienne. In: A Travers Lèspace de la Méthode: Les dimensions du Terrain en Géographie, Arras: França, 2008. 
CARDOSO, Thiago Mota. Malhas cartográficas técnicas, conhecimentos e cosmopolítica do ato de mapear territórios indígenas. São Paulo: IV Reunião de Antropologia da Ciência e da Tecnologia (IV REACT) - UNICAMP; 2013.

CASÉ. Entrevista concedida à Lidiana Cruz da Costa. São Paulo; 2015.

CASTRO, Edna. Território, Biodiversidade e Saberes de Populações Ambientais. In: DIEGUES, Antônio Carlos. Etnoconservação novos rumos para a proteção da natureza nos trópicos. São Paulo: Annablume e HUCITEC, Nupaub - USP 2000 , p. $165-182$ (Vol 2).

CASTRO, Eduardo Viveiros de. Encontros - A Arte da Entrevista - Eduardo Viveiros de Castro. Brasil: Ed. AZOUGUE EDITORIAL; 2008.

CLASTRES, Pierre. La Sociedad contra el Estado. Espanha: Edición Virus editorial; 2010.

COSTA, Lidiana C. Território e Territorialidades da Comunidade Indígena Guarani Tenondé Porã. Ourinhos, Trabalho Conclusão de Curso da Universidade Estadual "Júlio de Mesquita Filho", 2014.

DEBARBIEUX, Bernard. Représentation. In Lévy Jacques et Michel Lussault (Ed.) Dictionnaire de la géographie et de léspace des sociétes. Paris: Berlin, 2003.

DESCOLA. Philippe. Ecologia e Cosmologia. In: Etnoconservação novos rumos para a proteção da natureza nos trópicos. São Paulo: Annablume e HUCITEC Nupaub - USP, 2000, p. 165 - 182 (vol. 2).

DIÁRIO OFICIAL DA UNIÃO. Precedente FUNAI. 2012, p. 19.

DIEGUES, Antônio Carlos. O Mito Moderno da Natureza Intocada. São Paulo: Ed. Hucitec, 2001.

DIEGUES, Antônio Carlos. Água e Cultura nas Populações Tradicionais Brasileiras. São Paulo: I Encontro Internacional: Governança da Água, 2007.

DURHAM, E. R. O lugar do índio. Novos Estudos. São Paulo, CEBRAP, v. 1, n. 1, p. 45-49, 1982.

FARIA, Camila Salles. A luta Guarani pela Terra na metrópole paulistana: contradições entre a propriedade privada capitalista e a apropriação indígena. São Paulo: Tese (Doutorado em geografia), FFLCH/USP, 2016. 
FARIA, Camila Salles. A integração precária e a resistência indígena na periferia da metrópole. São Paulo: Dissertação (Mestrado em geografia), $\mathrm{FFLCH}$, 2008.

FONSECA, Fernanda Padovesi. A inflexibilidade do espaço cartográfico, uma questão para a Geografia: análise das discussões sobre 0 papel da Cartografia. São Paulo, Tese (Doutorado em Geografia), FFLCH/USP, 2004. Disponível em: http://www.teses.usp.br/teses/disponiveis/8/8135/tde-09082010130954/pt-br.php

FONSECA, Fernanda Padovesi; GIRARDI, Eduardo P. Cartografia participativa. In: FERNANDES, José Alberto Rio; TRIGAL, Lorenzo Lopez; SPOSITO, Eliseu (Coord.) Dicionário de Geografia Aplicada. Porto: Porto Editora, 2016. p: 68-69.

FUNAI (org.). Fundação Nacional do Índio. Coordenação Geral de Gestão Ambiental - Plano de gestão territorial e ambiental de Terras indígenas: diretrizes. Brasília. 2013

GALLOIS, Dominique Tilkin. "Nossas falas duras" Discurso político e auto representação Waiapi. In: Org. RAMOS, Alcida Rita; ALBERT, Bruce. Pacificando o Branco: Cosmologias do contato no Norte-Amazônico. São Paulo: Editora UNESP, 2002.

GIRARDI, Gisele. A cartografia e os mitos: ensaios de leitura de mapas. São Paulo: Dissertação (Mestrado em Geografia Física) - Faculdade de Filosofia, Letras e Ciências Humanas, Universidade de São Paulo. 1997. 148 p.

GOMIDE, Maria Lúcia Cereda. MARÃNÃ BODODI - a territorialidade Xavante nos caminhos do Ró. São PauloTese de doutorado apresentada para o departamento de geografia física - USP, 2008.

GOMIDE, Maria Lúcia; SANTOS, Alex Mota. Registro de Terras Indígenas por meio de Mapas Mentais. São Paulo: Rev. Cult. e Ext. USP, n. 13, 2015, p. 55-63. Disponível em: http://dx.doi.org/10.11606/issn.2316-9060.v13i0p55-63

GOULD, Peter; WHYTE, R. Mental Maps. Harmondsworth: Penguin Books,1974.

HAESBAERT. Rogério. Territórios Alternativos. São Paulo: Contexto, 2006. 
HARLEY, Brian. "Mapas, saber e poder", Confins [Online], 5 | 2009, posto online em 24 avril 2009. Traduzido por Mônica Balestrin Nunes URL: http://confins.revues.org/index5724.html

. La Nueva Naturaleza de los mapas: Ensayos sobre la história de la cartografia. México: Fondo de Cultura Económica, 2005. p. 59-78.

1989. p. 1-20,

Deconstructing the map. Cartographica. Toronto, v. 26, n. 2.

.A nova história da cartografia. Brasil: O Correio da UNESCO (Mapas e cartógrafos); no 8. 1991. p. 4-9.

HIRT, Irène. Mapeando Sueños/Soñando mapas: Entrelazando Conocimientos geográficos Indígenas y Occidentales. Revista geográfica del Sur, 2013, vol. 3/1, p. 63-90.

HOFFMANN, M. B. Mapeamentos participativos e atores transnacionais: a formação de identidades políticas para além do Estado e dos grupos étnicos. In: ACSELRAD, H. Cartografia social e dinâmicas territoriais: marcos para 0 debate. Rio de Janeiro: Universidade Federal do Rio de Janeiro, Instituto de Pesquisa e Planejamento Urbano e Regional, 2010, p. 47-80.

JOLIVEAU, T. O lugar dos mapas nas abordagens participativas. In: Henri Acselrad (org.) Cartografias Sociais e Território. Rio de Janeiro, RJ: UFRJ/IPPUR, 2008.

KOK, Glória. Vestígios Indígenas na cartografia do Sertão da América Portuguesa. Anais do Museu Paulista. São Paulo. N. Sér. V. 17. n. 2. 2009. p. 91.

KOPENAWA, Albert, Bruce, Davi A queda do céu : Palavras de um xamã yanomami / Davi Kopenawa e Bruce Albert . Tradução Beatriz Perrone-Moisés; prefácio de Eduardo Viveiros de Castro - 1a ed. - São Paulo: Companhia das Letras, 2015.

LADEIRA, I. L e AZANHA, G. Os Índios da Serra do Mar. São Paulo: Nova Stella Editora, 1988.

LADEIRA, Maria Inês. Terras indígenas e unidades de conservação na Mata Atlântica - Áreas Protegidas?. In: "Terras Indígenas e Unidades de 
Conservação da Natureza - o desafio das sobreposições". ISA - Instituto Socioambiental. Centro de Trabalho Indigenista. Brasil; 2003.

. O Caminhar sob a luz. O Território M'byá à beira do oceano. São Paulo: Dissertação (Mestrado em Ciências Sociais - Antropologia). Pontifícia Universidade Católica, 1992.

Constituição e Uso. São Paulo, Edusp, 2008.

Espaço geográfico Guarani-Mbya: Significado, LADEIRA, I. L e GUARANI, L. Condições Ambientais do Território Guarani: Implicações no Modo de Vida. Campo Grande -MS: Tellus, ano 4, n. 6, 2004, 51-63 p.

LÉVY, Jacques. Uma virada cartográfica? In: ACSELRAD, Henri (org.). Cartografias sociais e território. Rio de Janeiro: UFRJ/IPPUR, 2008. p. 153-167.

LÉVY, Jacques; LUSSAULT Michel. Paradigma euclidiano. In : LÉVY, Jacques; LUSSAULT Michel (Org.). Dictionnaire de la Géographie et de I'espace des sociétés. Paris: Belin, 2003. Tradução Jaime Oliva; Fernanda Padovesi Fonseca.

LÉVY, Jacques. Euclidien (Espace). In: LÉVY, Jacques; LUSSAULT, Michel (Org.). Dictionnaire de la Géographie et de l'espace des sociétés. Paris: Belin, 2003. p. 351. Tradução de trabalho de Fernanda Padovesi Fonseca e Jaime Tadeu Oliva

LITAIFF, ALDO."KESUITA" Guarani: Mitologia e Territorialidade. Porto Alegre: In: REVISTA Espaço Ameríndio, v. 3, n. 2. 2009. 142-160 p.

MARTINELLI, Marcello. Mapas da geografia e cartografia temática. São Paulo: Contexto, 2006.

MILAGRES, Cleiton Silva Ferreira; FERREIRA NETO, José Ambrósio; SOUSA, Diego Neves. $O$ Uso dos Sistemas de Informação Geográfica Participativos (Pgis's) na Representação Territorial de Comunidades. Anais. Pernambuco : Congresso ALASRU, 2010.

OTERO, Andrea Grazziani. Territorialidade $\mathbf{X}$ deslocamento: fronteiras na compreensão de uma identidade Myá- Guarani. Salvador-Bahia: In: XI Congresso Luso Afro-brasileiro de Ciências Sociais: 2011.

PARDINI, Patrick. Natureza e Cultura na Paisagem Amazônica: Uma Experiência Fotográfica com ressonâncias na cosmologia ameríndia e na 
ecologia histórica. Belém: Bol. Mus. Para. Emílio Goeldi. Cienc. Hum. v. 7, n. 2, 2012, 589-603 p.

PONCET, Patrick. "Visões do Mundo", Confins [Online], 18|2013. Tradução de Ludmila Girardi e Paulo Fernando Meliani. Disponível em: http://confins.revues.org/8448

ROBERT, Pascale. Terre coupée: Recomposition des territorialités indigènes dans une réserve d'Amazonie. ResearchGate -[online], 05/2015. Disponível em: http://www.researchgate.net/publication

SANTOS, Milton. Pensando o espaço do homem. São Paulo: Edusp, 2004

STASZAK, Jean-François. Mapas Mentais. In: LÉVY, Jacques; LUSSAULT Michel (Org.). Dictionnaire de la Géographie et de l'espace des sociétés. Paris : Belin, 2003. p: 132-133.Tradução de Jaime Tadeu Oliva.

RAFFESTIN, Claude. Por uma Geografia do Poder. Tradução de Maria Cecília. São Paulo: Ática, 1993.

VIDAL, L.B. O mapeamento simbólico das cores na sociedade indígena Kayapó-Xikrin do Sudoeste do Pará. In: SILVA, A. L.; FERREIRA, M. K. L. Antropologia, História e Educação: a questão indígena e a escola. São Paulo: Global, 2. ed., 2001. 


\title{
SITES CONSULTADOS
}

\author{
www.funai.gov.br \\ www.siscom.ibama.gov.br \\ www.cimi.org.br \\ http://www.cpisp.org.br/indios/pages/11813.swf \\ www.yvyrupa.org.br/ \\ www.imprensaoficial.com.br \\ www.yvyrupa.com.br. \\ www.Guarani.map.as \\ www.camara.sp.gov.br; \\ www.brasildefato.com.br \\ www.cecitenondepora.blogspot.com.br; \\ www.periferiaemmovimento.com.br \\ www.trabalhoindigenista.org.br \\ www.socioambiental.com.br
}

